U. S. DEPARTMENT OF AGRICULTURE. BUREAU OF PLANT INDUSTRY - BULLETIN N0. $21 \%$.

B. T. GALLUWAY, Chief of Bureau.

\title{
ROOT-KNOT AND ITS CONTROL.
}

BY

\section{ERNST A. BENSEY,}

Professor of Botany, Michigan Agricultural College, and Collaborator, Burcau of Plant Indusiry.

Issued NoYember 21, 1911.

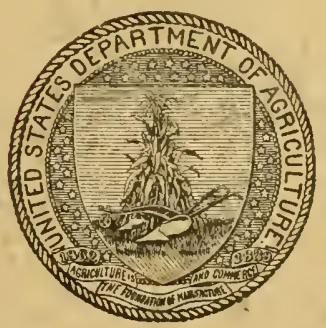

WASHINGTON :

GOVERNIENT PRINTING OFFICE. 


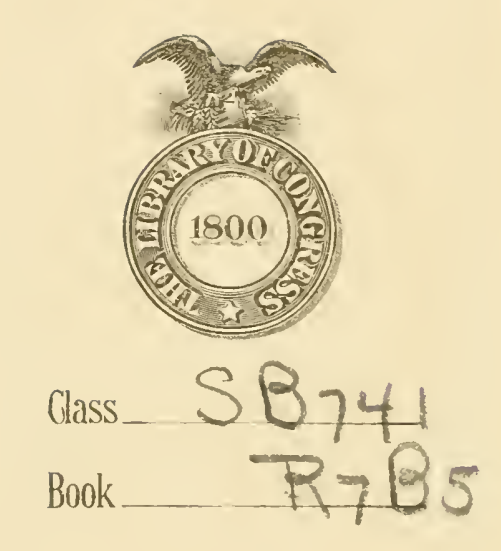










\title{
U. S. DEPARTMENT OF AGRICULTURE.
}

BUREAU OF PLANT INDUSTRY-BULLETIN N0. $21 \%$.

B. T. GALLOWAY, Chief of Bureau.

\section{ROOT-KNOT AND ITS CONTROL.}

\author{
BY \\ ERNST A. BESSEY, \\ Professor of Botany, Michigan Agricultural College, and \\ Collaborator, Bureau of Plant Industry.
}

Issuen November 21, 1911.

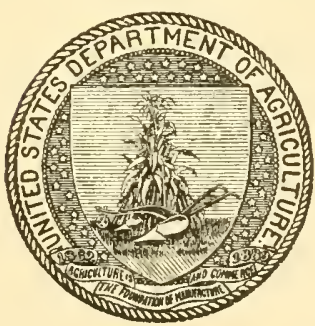

WASIINGTON :

GOVERNMENT PRINTING OFFICE.

1911.

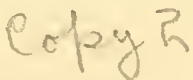




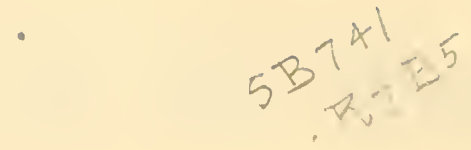

\section{BUREAU OF PIANT INDUSTRY.}

Chief of Butcau, Beverly T. Galloway.

Assistant Chief of Bureau, WILLIA A. TAYLoR.

Editor, J. E. ROCKWELL.

Chiff Clerk, JAMES E. Jones.

\section{Cotton and Truck Disease and Sugar-Plant Investigations.}

SCIENTIFIC STAFT.

W. A. Orton, Pathologist in Charge.

H. A. Edson and J. B. Norton, Physiologists.

W. W. Gilbert, L. L. Harter, II. B. Shaw, F. J. Pritchard, F. A. Wolf, and H. W. Wollenweber, A ssistant Pathologists.

C. F. Clark, G. F. Miles, Clara O. Jamieson, Ethel C. Field, W. B. Clark, and A. C. Lewis, Scientific A ssistants.

E. C. Rittue, Joseph F. Reed, J. Rosenbaum, and L. O. Watson, Assistants. 


\section{LETTER OF TRANSMITTAL.}

\section{U. S. Department of Agriculture, Bureau of Plant Ixdustry, Office of tile Chref, Tashington, D. C., A pril 10, 1911.}

SIR: I have the honor to transmit herewith and to recommend for publication as Bulletin No. 217 of the series of this Bureau a manuscript entitled "Root-Knot and Its Control," by Dr. Ernst A. Bessey, professor of botany, Michigan Agricultural College, formerly a plant pathologist in this Bureau and now a collaborator of the Bureau of Plant Industry. This bulletin presents the results and conclusions of studies made by the author while in the service of the Bureau.

Root-knot, which is widespread through the warm temperate and tropical zones of the whole world, is especially prevalent in this country in the South, and, as the bulletin shows, it is present even in the cold parts of the Northern States. It is also a very serious disease of greenhouse plants all over the country. Fortunately, it is almost exclusively confined to the lighter types of soils, causing little or no damage in stiff clays. Dr. Bessey has worked out under field conditions a practical method of holding the pest in check. The means of its control in greenhouses had already been worked out, so that the methods presented here for controlling the pest in greenhouses offer little that is new. The list of plants susceptible to this disease is more complete than any previous list published, containing more than double the names of any other list.

Respectfully,

Hon. James Wilson,

Wy. A. TAYLOR, Acting Chief of Bureau.

Secretary of Agriculture. 



\section{CONTENTS}

Page.

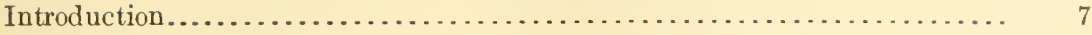

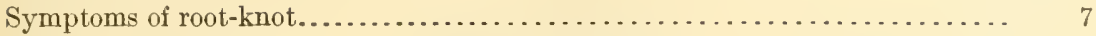

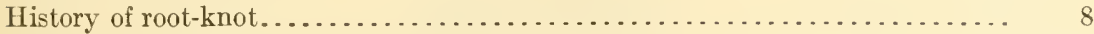

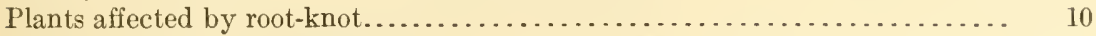

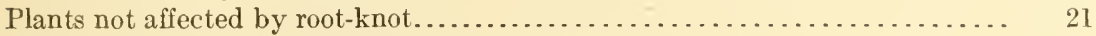

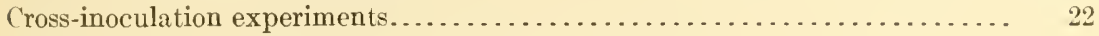

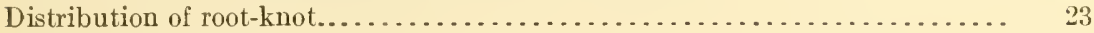

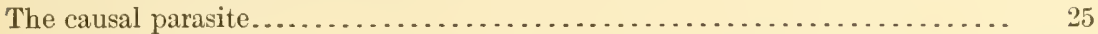

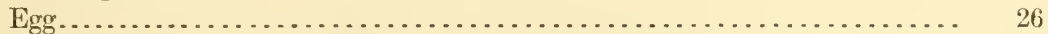

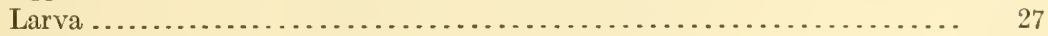

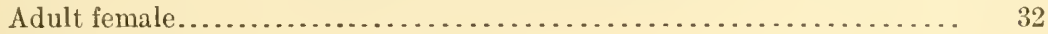

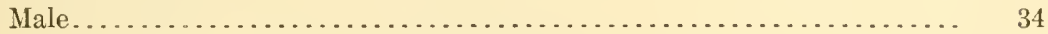

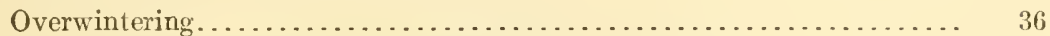

Comparison with Heterodera schachtii.................... 36

Methods of spread ................................... 37

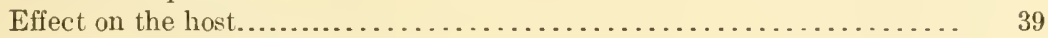

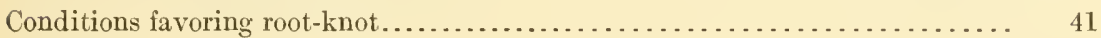

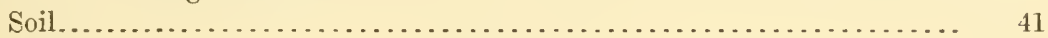

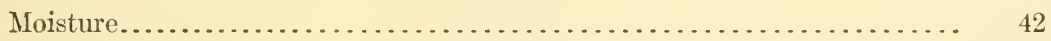

Temperature.................................... 42

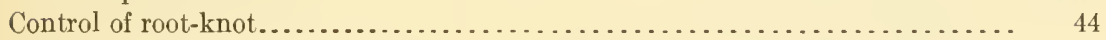

Greenhouses, seed beds, etc............................. 44

Live steam ....................................... 44

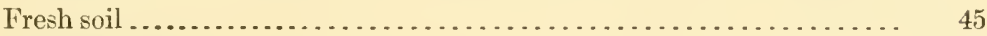

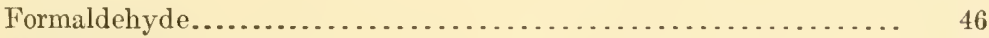

Miscellaneous.................................... 48

Control of root-knot in the field on perennial crops................ 48

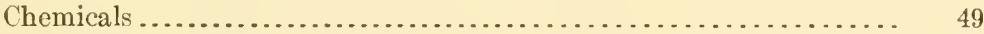

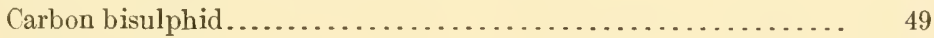

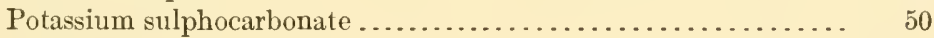

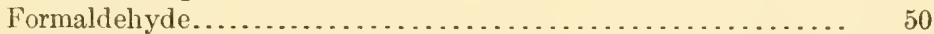

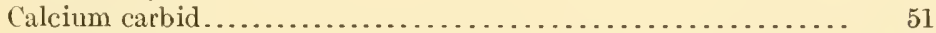

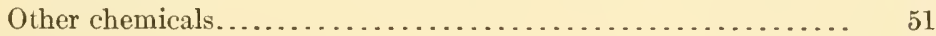

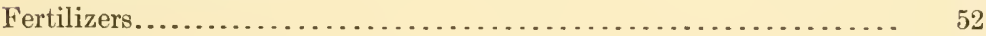

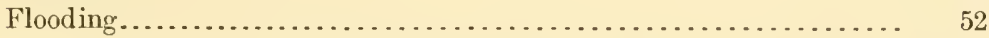

Control of root-knot in the field when no crop is present............ 53

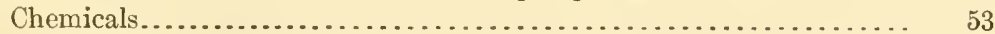

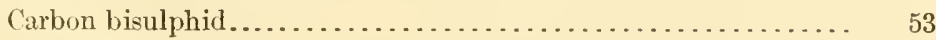

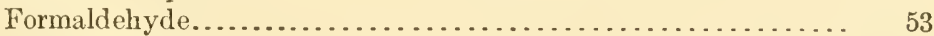

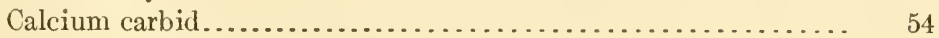

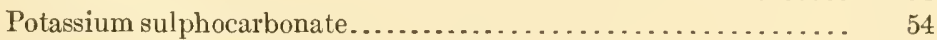

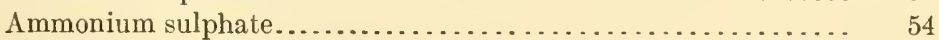

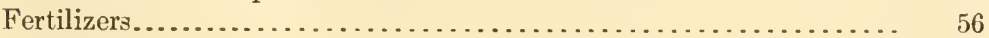

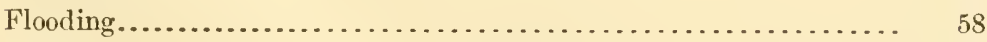

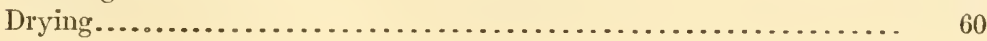


Control of root-knot-Continued.

Control of root-knot in the field when no crop is present-Continued. Page.

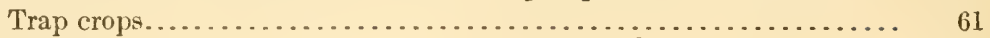

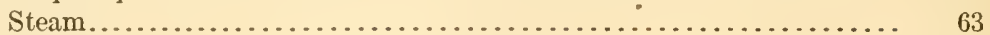

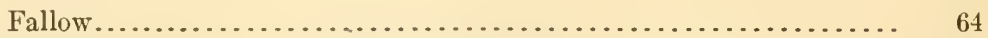

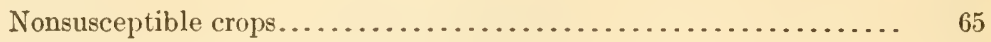

Recommendations for freeing a field from root-knot.................. 69

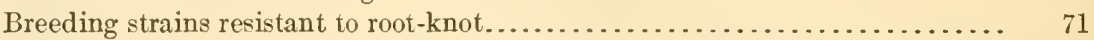

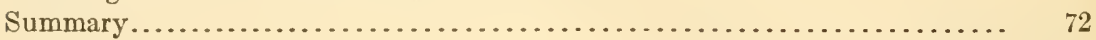

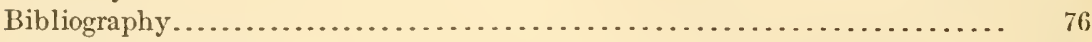

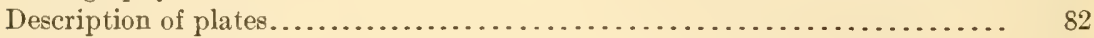

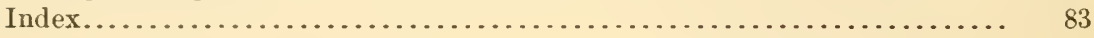

\section{ILLUSTRATIONS.}

PLATES.

Page.

Plate I. Stages in the development of Heterodera radicicola (Greef) Müll., ef́c.

II. Fig. 1-Root-knot on sugar beet. Fig. 2-Root-knot on squash......

III. Fig. 1-Root-knot on carrot. Fig. 2-Root-knot on clover...........

TEXT FIGURES.

FIG. 1. Heterodera radicicola. Half-grown female (?) individual shortly

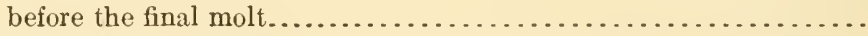

2. Anterior portion of same nematode shown in figure $1 . . . . . . . . .$.

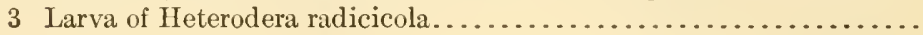


B. P. I. -667 .

\section{ROOT-KNOT ANI) ITS CONTROL.}

\section{INTRODUCTION.}

The disease of plants known as root-knot, beaded root-knot, rootgall, eelworm disease, big-root, and probably under other names has been present in the United States for many years and has caused losses whose extent can not be calculated. Although more abundant in the South, it is present, at least sporadically, in all but the most Northern or Northwestern States as an out-of-doors pest and is everywhere distributed in greenhouses.

\section{SYMPTOMS OF ROOT-KNOT.}

The presence of root-knot becomes noticeable when the affected plants become dwarfed or begin to die, but it is often present and causing a great reduction in the crop yield without the grower's knowledge. Indeed, it is probable that greater actual loss occurs from the form of the disease where, to the untrained eye, no signs are visible than in the case where the plants are actually killed, for a farmer soon learns by experience not to plant in infected regions those crops liable to total destruction, while he fails to notice a reduction in yield, especially if the disease be well established and not a recent introduction, so long as the affected plants do not show too great dwarfing or discoloration.

Aside from the killing or dwarfing of the plants in severe cases or the reduction of yield in less serious infections there are no very noticeable symptoms apparent on those parts of the plant above ground. If rainfall has been rather scanty during the summer, the affected plants first show the lack of sufficient water, while sometimes the wilting is apparent when the sun is hot, even with abundant soil moisture. Occasionally no discoloration is noticeable, but usually plants that are badly affected show a lighter shade of green than unaffected plants. Since, however, the clisease usually occupies large areas when it has been long established, there would be no opportunity ordinarily to compare affected with unaffected plants in mass, so that this difference would be readily overlookedi.

On the roots, on the contrary, very marked structural changes are apparent. Instead of being smooth and of uniform or slowly 
decreasing diameter toward the tip, they show irregular enlargenents which involve the whole root if it be small or sometimes only one side of a large root. (Pls. II and III.) These are not superficial swellings only slightly attached to the root, as in the case of the bacterial tubercles of leguminous plants, but are integral parts of the root itself. On small roots these swellings may vary from only slightly greater than the thickness of the root to twice as thick, and spherical to spindle shaped; on larger roots they are usually lateral, or in bad cases may involve all sides, making a gall many times the normal diameter of the root and covered with furrows and seams until the root loses all semblance of its normal appearance. Such compound knots may reach a diameter of 3 or, rarely, even more centimeters and a length many times as great.

\section{HISTORY OF ROOT-KNOT.'}

Root-knot has been known for many years both in the United States and abroad. It was apparently first mentioned in print by the famous mycologist Rev. M. J. Berkeley, ${ }^{2}$ who described and figured roots of plants affected by this disease and recognized the animal nature of the organism causing it. The galls were observed by Greef on grass roots in 1864 , but it was not until 1872 that the parasite received a name, ${ }^{3}$ Anguillula radicicola Greef, after it had been obserred several times on a number of different plants. In 1879 Cornu described this species, observed by him on sainfoin in 1874 , as $A$. marioni. In 1882 and 1885 the well-known plant pathologist, Prof. A. B. Frank, described it as a serious enemy of a number of cultivated plants in Germany. In 1883 and 1884 C. Müller made a careful study of the organism causing the disease and placed it in the genus Heterodera under the name of Heterodera radicicola (Greef) Müller. He showed it to be a close relative of the destructive sugar-beet nematode Heterodera schachtii Schmidt, which has caused so much injury to the beetsugar industry in Europe and which the writer found in 1907 in scattered localities in the United States. Treub in 1885 described as a parasite of sugar cane in Java what he considered to be a new species, naming it Heterodera javanica. This is considered now by most authors to be a synonym of $H$. radicicola.

In the United States the root-knot early attracted the attention of greenhouse men as a serious pest of roses, violets, and other plants. J. N. May states ${ }^{4}$ that he saw the disease, which he calls "club-root," on violets in 1876 . We find the florists' papers full of references to

\footnotetext{
1 The full titles of all papers mentioned in this bulletin will be found in the "Bibliography," pp. $76-81$. The $a, b, c$ following a date, if given, refer to the first, second, and third papers published if more than one paper in that year is referred to.

2 Berkeley, 1855.

3 Greef, 1864 and 1872.

May, 1888.
} 
this trouble in the late eighties and early nineties. The first extensive investigation in this country was undertaken by Dr. J. C. Neal, ${ }^{1}$ of the Florida Agricultural Experiment Station, for the Division of Entomology of the United States Department of Agriculture. Owing to lack of access to literature he did not identify it with the pest previously described in Europe, but gave it the name Anguillula arenaria. Dr. N. A. Cobb, ${ }^{2}$ then of New South Wales, in the absence of specimens from America, provisionally accepted Neal's species as distinct from the European species, renaming the former Tylenchus arenarius and the latter T. radicicola. He described the injury caused by it in New South Wales, and gave recommendations as to treatment. In 1889 Prof. G. F. Atkinson, then connected with the Alabama Polytechnic Institute, at Auburn, Ala., described the disease, paying special attention to the life history of the parasite, which he correctly identified with the European species. In 1898 Stone and Smith, of the Hatch Agricultural Experiment Station, published the most complete account yet written of the treatment of the trouble in greenhouses, at the same time giving some excellent illustrations of the parasite in various stages of development.

In 1892 Göldi described a nematode parasitic on the roots of coffee in Brazil under the name Meloidogyne exigua. This proved subsequently to be islentical with Heterodera radicicola. Finally, in 1901, Lavergne, evidently misled by an erroneous statement as to the dimensions of Heterodera radicicola, described this species from Chile as Anguitlula vialae.

The foregoing is by no means a complete list of the publications on the subject but embraces the papers that bear on the question of its synonymy and its occurrence in this country.

The synonymy of the causal parasite is, then, as follows:

Heterodera radicicola (Greef) Müller, 1883.

Syn. Anguillula radicicola Greef, 1872.

marioni Cornu, 1879.

arenaria Neal, 1889.

vialae Lavergne, 1901.

Heterodera javanica Treub, 1885. (?)

Tylenchus arenarius Cobb, 1890.

radicicola Cobb, 1890.

Meloidogyne exigua Göldi, 1892.

The writer's investigations of the subject were begun in 1900, but were soon interrupterl for a period of years. Not until 1905 was the work resumed in earnest and pursued with various interruptions until its completion. The work was done partly at Washington, D. C., but mainly at Miami, Fla., at the Subtropical Laboratory and Garden of the Bureau of Plant Industry, and at Monetta, S. C.,

1 Neal, 1889. 
the majority of the field experiments being made at the last-named place. In addition to this, trips were made to the various parts of the country where the disease occurs or was suspected to occur.

The caring for the experimental plats at Monetta, as well as the making of many of the observations on these experiments, was performed by Mr. J. M. Johnson, without whose services much of the writer's work would have been impossible. At Miami the cooperation of Mr. P. J. Wester, at that time gardener of the Subtropical Laboratory and Garden, was also of considerable assistance, although the experiments there were not on so large a scale as at Monetta.

\section{PLANTS AFFECTED BY ROOT-KNOT.}

The nematode causing root-knot seems to be one of the most omnivorous known. Neal, in 1889, reported about 65 species of plants as more or less subject to attacks by this pest. Reports by other investigators in different parts of the world and extensive experiments and observations by the writer have increased this number to 480 species and subspecies. Of this total number the writer has personally observed it on 291. The most complete list hitherto is that of Dr. Kati Marcinowski, ${ }^{1}$ who lists 235 species (after subtracting hosts reported under two names). Almost all of the more important families of flowering plants are present in the list, as well as one gymnosperm and a fern. The plants include monocotyledons and dicotyledons, herbs and woody plants, annuals and perennials. Most of the garden plants are affected, as are many field crops.

The list of plants shown in Table $I$ is sure to be largely added to as investigations of this disease are earried on, and is not to be looked on as being in any way final. It is true that the writer has made many hundred examinations of plants in badly infested soil that did not take the disease, but such a list is of far less value than that of plants known to be susceptible. In the list are given (1) the scientific name of the plant; ${ }^{2}$ (2) in parenthesis, the name under which it was reported, if different from the name now used; (3) the common English name, if any; (4) the name of the person first reporting it on that host; (5) the date of observation; and (6) the degree of injury. Where the disease is reported on the host for apparently the first time, the name of the first observer is omitted, the observation having been made by the writer. In all cases where the writer has seen the plant

\footnotetext{
1 Marcinowski, Kati, 1909.

2 The nomenclature followed is that used by the systematic botanists of the Bureau of Plant Industry. The list was submitted to the office of Taxonomic Investigations of that Bureau, where it was revised by Mr. Homer C. Skeels. In a numter of eases it would have been impossible, without seeing specimens, to determine to which of several segregates of a species the plant listed might belong, and in that case the original species name was retained, if still valid.
} 
affected, whether previously reported or not, the name in the first column is preceded by an asterisk (*). In the last column the letters indicate the degree of injury only on those plants observed by the writer, the severest injury observed being reported, even though less severe cases have been observed-a=severe injury; $b=$ nematodes abundant, but injury apparently not great; $e=$ nematodes not abundant and no injury observed. It must be understood that under different circumstances many plants marked "a" would show little injury, while plants observed as uninjured and noted as " $e$ " might easily be severely harmed under different conditions. Too much dependence can not, therefore, be laid on this column. In a number of cases the writer has grown in very badly infested fields plants reported by others as susceptible to root-knot, without the slightest signs of infection. Such cases are indicated in the list by a dagger $(\dagger)$. Some of these cases may be of species that are susceptible only under special conditions, while others may be due to erroneous observation on the part of the first observer or perhaps to the confusion of the bacterial root tubercle with the nematode gall. The former surmise may explain why the writer during a three years' residence in a part of Florida where the disease is very abundant failed to find it in any species of Citrus. Dr. H. J. Webber and Prof. P.H. Rolfs, who have studied plant diseases in Florida for many years, confirm this. Yet Dr. J. C. Neal ${ }^{1}$ reports it as occurring on lemon, orange, and bittersweet orange, while a similar report is made by Lavergne from Chile. ${ }^{2}$

In the list those names added on the authority of Marcinowski ${ }^{3}$ are indicated by a double dagger $(\ddagger)$ before the name of the plant.

\section{TABLE I.-List of plants susceptible to root-knot.}

[An asterisk (*) is used to show those plants which the writer has found affected with root-knot, and a dagger $(\uparrow)$ those which he has grown in infested fields without infection, while a double dagger $(f)$ shows the names of susceptible plants added on the authority of Marcinowski. In the last column a=severe injury; b, nematodes abundant, but injury apparently not great; $c$, nematodes not abundant and no injury observed.]

\begin{tabular}{|c|c|c|c|}
\hline Name of plant. & Name of observer. & $\begin{array}{l}\text { Date of } \\
\text { observa- } \\
\text { tion. }\end{array}$ & $\begin{array}{l}\text { Charac- } \\
\text { ter of } \\
\text { injury. }\end{array}$ \\
\hline *Abelmoschus esculentus (L) Moench. Okra.... & Neal............. & 1889 & a \\
\hline *Abroma augusta L. f.................... & $\ldots \ldots \ldots . . . .$. & $\ldots \ldots$ & $\mathrm{b}$ \\
\hline *Abrus precatorius L. Paternoster bean........ & ............... & (a) & $\mathrm{c}$ \\
\hline * Abutilon avicennae Gaertn. Chinese hemp.... & & & b \\
\hline 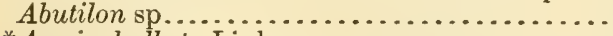 & Atkinson...... & 1889 & \\
\hline * Acacia dealbata Link. .................... & & & b \\
\hline $\begin{array}{l}\text { Acacia, several species from Australia. Wat- } \\
\text { tle. }\end{array}$ & C. P. Lounsbury ${ }^{4}$.. & 1908 & - . . \\
\hline 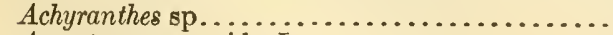 & Neal............ & 1889 & \\
\hline Ageratum conyzoides L........... & Breda de Haan..... & 1899 & \\
\hline 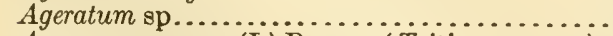 & Zimmermann ...... & $1900-1$ & $\ldots .$. \\
\hline $\begin{array}{l}\text { Agropyron repens (L) Beauv. (Triticum repens). } \\
\text { Quack-grass. }\end{array}$ & Greef............ & 1872 & $\ldots \ldots$ \\
\hline 2 Lavergne, 1901. & Marcinowski, 1909. & 'In letter. & \\
\hline
\end{tabular}


TABLE 1.-List of plants susccptible to root-knot-Continued.

\begin{tabular}{|c|c|c|c|}
\hline Name of pl & Name of observer. & $\begin{array}{l}\text { Date of } \\
\text { observa- } \\
\text { tion. }\end{array}$ & $\begin{array}{l}\text { Charae- } \\
\text { ter of } \\
\text { injury. }\end{array}$ \\
\hline ga reptans $\mathrm{L}$... & rotter............ & $1905-1$ & \\
\hline iaria officinalis Andrz. (Erysimum alliaria). & Trotter.......... & $1905-1$ & \\
\hline ium ascalonicum L. Shallot........... & $\ldots \ldots \ldots \ldots \ldots$ & $\ldots \ldots$. & b \\
\hline 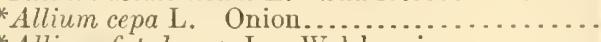 & & & $b$ \\
\hline ium fistulosum L. ITe & $\ldots$. & & h \\
\hline ium porrum L. Leek............. & $\ldots$. & & $\mathrm{c}$ \\
\hline haea rosea $(\mathrm{L})$ Cav. Hollyhock.... & $\ldots \ldots \ldots \ldots \ldots$ & $\ldots$. & a \\
\hline aranthus atropurpureus Roxb........... & $\ldots \ldots \ldots \ldots$. & ....... & c \\
\hline aranthus caudatus L. Love-lies-bleeding.. & $\ldots \ldots \ldots \ldots \ldots$ & $\ldots \ldots \ldots$ & c \\
\hline $\begin{array}{l}\text { Amaranthus graecizans L. (A. albus). Tum- } \\
\text { bleweed. }\end{array}$ & $\ldots \ldots \ldots$. & & b \\
\hline aranthus hybridus L. & $\cdots$ & $\cdots$ & $\mathrm{c}$ \\
\hline $\begin{array}{l}\text { Amaranthus hybridus forma hypochondriacus } \\
\text { (L.) Rob. Prince's feather. }\end{array}$ & ... & & c \\
\hline ranthus retroflexus $\mathrm{L}$. & Atki & 1889 & c \\
\hline ranthus spinosus L. & Neal.. & 1889 & $\mathrm{c}$ \\
\hline aranthus tricolor & $\ldots \ldots \ldots$ & $\ldots$. & a \\
\hline mi copticum L........ & $\ldots .$. & & $\mathrm{c}$ \\
\hline $\begin{array}{l}\text { Amygdalus communis } \mathrm{I} \text {. } \\
\text { Almond. }\end{array}$ & Nea & $1889 \ldots$ & \\
\hline gdalus persica L. $\mathrm{Pe}$ & ...do............ & 1889 & a \\
\hline nas sativus Schult. f. Pineapple........ & & & $\mathrm{b}$ \\
\hline choenanihus L................ & de Haan. & 18 & $\ldots$ \\
\hline nnina L.... & Trotter........ & $1905 \overline{-1}$ & ... \\
\hline $\begin{array}{l}\text { ethum graveolens } \mathbf{L} .1 \\
\text { getica archangelica L }\end{array}$ & & & c \\
\hline $\begin{array}{l}\text { Angelica archangelica L... } \\
\text { Angelica sylvestris L.... }\end{array}$ & oli........... & 1877 & $\ldots$ \\
\hline $\begin{array}{l}\text { Angelica sylvestris L... } \\
\text { Angclonia gardneri Hool }\end{array}$ & .....do... & 1877 & ... \\
\hline gclonia gardneri Hook. & .............. & $\ldots \ldots$ & a \\
\hline themis cotula L. May & & & $\mathrm{b}$ \\
\hline tirchinum majus L. Si & & & a \\
\hline 1 pium graveolens L. Cele & ........... & 1892 & a \\
\hline Arachis hypogaca L. Peanut............... & Neal............ & 1889 & $\ldots$ \\
\hline tium sp. Burdock... & Selby. & 1896 & \\
\hline 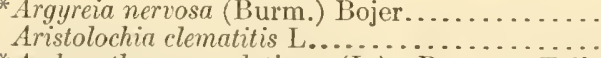 & $\cdots \cdots$ & 1896 & \\
\hline $\begin{array}{l}\text { Arrhenatherum elatius (L.) Beauv. Tall } \\
\text { meadow oat-grass. }\end{array}$ & & $\cdots$ & $\mathrm{c}$ \\
\hline & Col & & \\
\hline isia caudata & Neal. & 1889 & \\
\hline pias sp. Milkweed. & Frank. & 1896 & \\
\hline aragus officinalis $\mathrm{L}$. & & & $\mathrm{b}$ \\
\hline 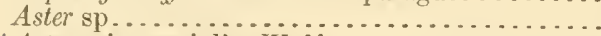 & & & \\
\hline a carn & Dalla Torre.. & 1892 & \\
\hline 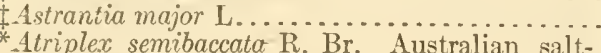 & 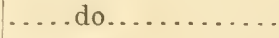 & 1892 & \\
\hline $\begin{array}{l}\text { Atriplex semibaccata R. Br. Australian salt- } \\
\text { bush. }\end{array}$ & & ... & c \\
\hline na sativa $\mathrm{L}$. Oats..... & Halsted. & 1891 & c \\
\hline 'Basella rubra L. Heart-leaved basel. & & & a \\
\hline Begonia coccinea Hooker. (B. rubra).. & Selby. . & 1896 & .. \\
\hline Begonia metallica L. Smith .......... & .... do. & 1896 & \\
\hline Begonia olbia Kuntze. (B. olvia)....... & & 1896 & \\
\hline nia rex Putz....... & Molliard......... & 1900 & \\
\hline Yor & $\ldots \ldots \ldots$ & $\ldots .$. & $\mathrm{b}$ \\
\hline Benincasa cerifera Savi. Wax gourd.. & & & a \\
\hline 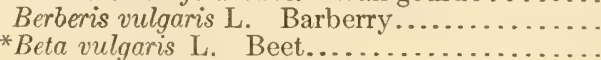 & Frank..... & 1885 & . \\
\hline $\begin{array}{l}\text { Beta vulgaris L. Beet.......................... (Helico- } \\
\text { Bihai pulverulenta (Lindl.) Kuntze. }\end{array}$ & do & $18 \$ 5$ & a \\
\hline $\begin{array}{l}\text { Bihai pulverulenta (Lindl.) Kuntze. (Helico- } \\
\text { nia pulverulenta). }\end{array}$ & Ross.............. & 1883 & \\
\hline
\end{tabular}


TABLE I.-List of plants susceptible to root-knot-Continued.

*Boerhaavia decumbens Vahl.

* Boerhaavia erecta I

Bosea amherstiana (Moq.) Hook. f. (Rodetia).

*Boussingaultia basselloides H. B. K. Madeira vine.

$\$$ Bouvardia $\mathrm{sp}$

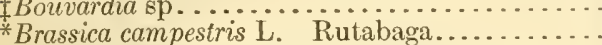

*Brassica juncea (L.) Cass. Chinese mustard. .

* Brassica napus L. Rape................ . .

* Brassica nigra L. Mustard...................

* Brassica oleracea botrytis L. Cauliflower, broccoli.

* Brassica oleracca capitata L. Cabbage.........

* Brassica pekinensis (Lour.) Skeels. Chinese cabbage.

*Brassica rapa L. Turnip.

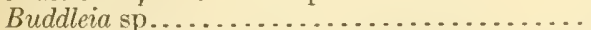

Bursa bursa-pastoris (L.) Britt. (Capsella bursa-pastoris). Shepherd's purse.

* Cajan indicum Spreng. Pigeon pea..........

Cananga odorata (Lam.) Hook, and Thom. Ylang-ylang.

* Canavali ensiforme (L.) DC. Jack bean......

* Capriola dactylon (L.) Kuntze. Bermuda grass.

* Capsicum annuum $\mathrm{L}$. (including C. cordiforme). Red pepper.

*Cardiospermum halicacabum L. Balloon vine.

* Carica papaya L. Papaya or melon pawpaw.

* Carissa bispinosa (L.) Desf.

Carpinus bctulus L. Beech...............

*Carthamus tinctorius L. Safflower............

* Carum carvi L. Caraway.................

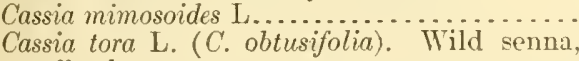
coffee bean.

Castanea sativa Miller (C. vesca). Chestnut..

* Catalpa speciosa Varder. Catal pa.......... .

* Cecropia palmata Willd....................

*Centaurea cyanus L. Cornflower.

Centratherum reticulatum (DC.) Benth .........

*Ceratonia siliqua L. Carob or St.-John'sbread.

*Chaetochloa italica (L.) Scrib. German millet.

* Chenopodium album L. Lamb's quarters....

* Chenopodium anthelminthicum L. Wormwood.

${ }^{*}$ Chenopodium boscianum Moq.

Chenopodium botrys L. Jerusalem oak.......

*Chenopodium sp. (Not any of the preceding).

Chrysanthemum cinerariaefolium (Trev.) Vis..

¥Chrysanthemum leucanthemum L. Oxeye daisy.

${ }^{*}$ Chrysanthemum sp. Chrysanthemum.........

* Cicer arietinum L. Chick-pea...............

${ }^{*}$ Cichorium endivia L. Endive.................

Cichorium intybus L. Chicory..............

Cinchonasp. Peruvian bark.

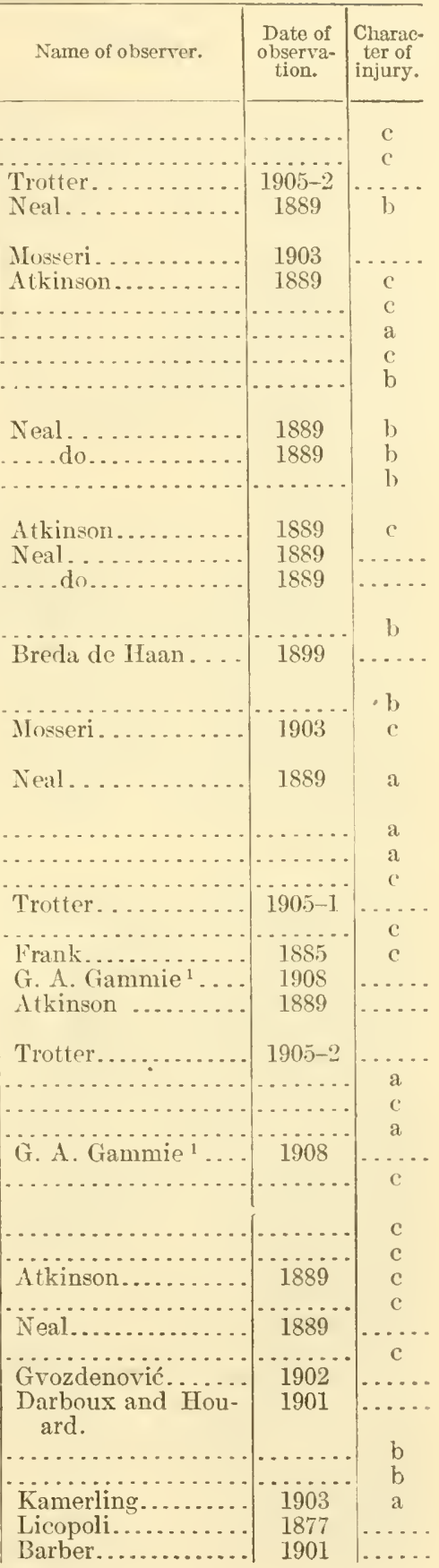


TABLE I.-List of plants susceptible to root-knot-Continued.

Name of plant.

Circaea intermcdia Ehrh.

Circaca lutetiana L. Enchanter's nightshade.

* Citrullus vulgaris Schrad. Watermelon.......

Citrus aurantium L. (C. vulgaris). Bitter orange.

Citrus aurantium sinensis L. (C. aurantium). Sweet orange.

Citrus limonum Risso.

$\ddagger$ Clemat is florida Thunb.

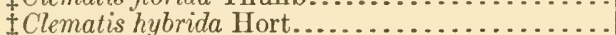

‡lematis lanuginosa Lindl. and Paxt............

* Clematis paniculata Thunb.

$\ddagger$ Clematis patens Morr. and Decais.

Clematis vitalba $\mathrm{L}$.

Clematis viticella $\mathrm{L} \ldots \ldots \ldots \ldots . . . \ldots . . . . .$.

Clematis sp.

* Coffea arabica L. Coffee

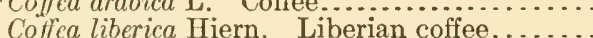

Coffea robusta Hort. Robusta coffee.

Coleusblumei Benth. (C.verschaffelti). Coleus.

Coleus scutellarioides (L.) Benth. Coleus.....

Coleus sp. (Coleus var. sp.). Coleus.

* Corchorus olitorius L. Jute.

* Coriandrum sativum L. Coriander.

* Coronopus procumbens Gilib.

Corylus avellana L. Filbert.

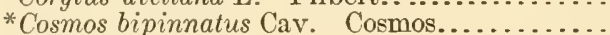

Crepis leontodontoides Allioni. Hawk'sbeard.

$\$$ Crepis pulchra L.

* Crotalaria juncea L. Sunn hemp.

*Croton glandulosus simpsonii Ferg.

* Cucumis melo L. Muskmelon..

* Cucurbita maxima Duch. Squash.

* Cucurbita moschata Duch. Squash.

* Cucurbita pepo L. Pumpkin, squash........

Cuminum cyminum $\mathrm{L}$. Cumin.

* Cyamopsis tetragonoloba (L.) Taub. Guar...

†yclamen europaeum L. Cyclamen............

Cyclamen persicum Mill. Cyclamen.

*Cydonia oblonga Mill. Quince.

* Cyperus esculentus L. Chufa.

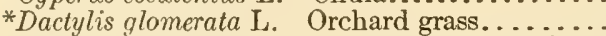

Dahlia pinnata Cav. (D. variabilis). Dahlia..

Datisca cannabina L.....................

* Daucus carota L. Carrot.

Desmodium sp.

* Deutzia crenata $\mathrm{S}$. and Z. Deutzia............

*Dianthus barbatus L. Sweet William.

*Dianthus caryophyllus L. Carnation.........

*Dianthus chinensis heddewiqi Regel. Pink...

* Dianthus plumarius L. Pink.

†Dieffenbachia sp.................

Name of observer.

\begin{tabular}{c|c}
$\begin{array}{c}\text { Date of } \\
\text { observa- } \\
\text { tion. }\end{array}$ & $\begin{array}{c}\text { Charac } \\
\text { ter of } \\
\text { injury }\end{array}$ \\
\hline
\end{tabular}

Tischler.

1902

1902

Neal.

1889

1889

$\cdots \ldots$

Neal...

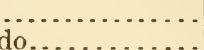

a

...do............

1889

do.

1889

Chifflot

1900

do...........

1900

1900

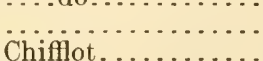

Cornu.

1900

Chifflot.............

1879-2

Müller.

1900

Jobert.

1884

Bouquet de la Grye.

Cramer.

Frank...............

1878

1899

1906

Breda de Haan....

1885

Neal.

1905

.....

.....................

1889

Trotter...............
Darboux and Hou-
$\quad$ ard.

......

c

1898 ......

$1905-1$

C

....

$\ldots \ldots$

a

-...

$\ldots \ldots$

a

...

- n

-....

$+\ldots$

$\ldots$

....

1901

Neal...................

1889

Berkeley...........

........................

a

Frank...............

Peglion................

$\ldots \ldots$

1885

1902

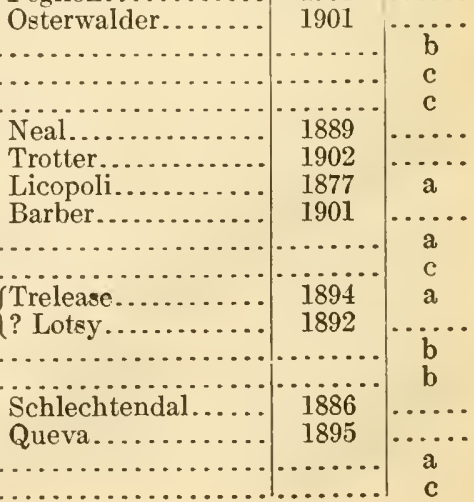

*Diospyros kaki L. f. Japanese persimmon...

*Diospyros virriniana L. Persimmon. 
TABLE I.-List of plants susceptible to root-knot-Continued.

Dipsacus fullonum L. Teasel.

Name of plant.

$\ddagger$ Dipsacus sylvestris Huds.

Dodartia orientalis $\mathrm{L}$

(T.

*Dolicholus intermedius (T. and G.) Vail .......

*Dolichos biflorus L.

*Dolichos lablab L. Hyacinth bean or Bonavist bean.

*Dolichos umbellatus Thunb.

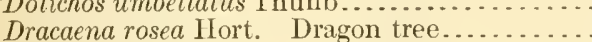

*Eclipta alba (L.) Hask.

$\ddagger$ Elcocharis palustris (L.) R. Br

*Elcusine coracana (L.) Gaertn. Ragi millet..

*Eleusine indica (L.) Gaertn. Wire-grass.....

*Elichrysum bractcatum (Vent.) Andr. Immortelle.

Elymus arenarius L. Downy lyme-grass .

*Emilia sagittata (Vahl.) DC. Scarlet tassel flower.

* Eruca sativa Mill. Roquette................

* Erythrina americana Mill. Coral tree..........

Erythrina cristagalli $\mathrm{L}$

* Eschscholtzia californica Cham. Califorvia poppy.

Eupatorium capillifolium. (Lam.) Small. (E. focniculaceum).

Euphorbia cyparissias L. Cypress spurge....

* Euphorbia nutans Lag. . . . . . . . . . . . . . . .

Euphorbia peplis L. Leafy spurge.

* Euphorbia pilulifera L...................

* Fagopyrum vulgare Hill. Buckwheat........

* Festuca elatior L. Meadow fescue...........

* Fcstuca ovina L. Sheep fescue..............

* Ficus aurea Nutt. Strangling fig. Wild rubber plant.

* Ficus carica L. Fig.....................

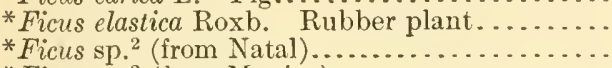

* Ficus sp. ${ }^{2}$ (from Mexico) ....................

* Foeniculum vulgarc Hill. Sweet feunel......

* Fragaria chiloenesis (L.) Duches. American strawberry.

Fragaria vesca L. European strawberry .

$\ddagger$ Fuchsia sp. Fuchsia.....................

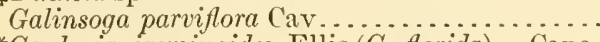

${ }^{*}$ Gardenia jasminoides Ellis $(G$. florida). Cape jasmine.

*Gladiolus sp. Gladiolus...

* Glycinehispida (Moench) Maxim. (Soja bean.) Soy bean.

*Gossypium barbadense L. Sea Island cotton.

* Gossypium hirsutum L. Upland cotton.....

* Grabowskia glauca Hort........................ Australian sarsaparilla.

* Hedysarum coronarium L. Sulla........... Helianthus annuus L. Sunflower.

* Helianthus debilis Nutt. Sunflower.

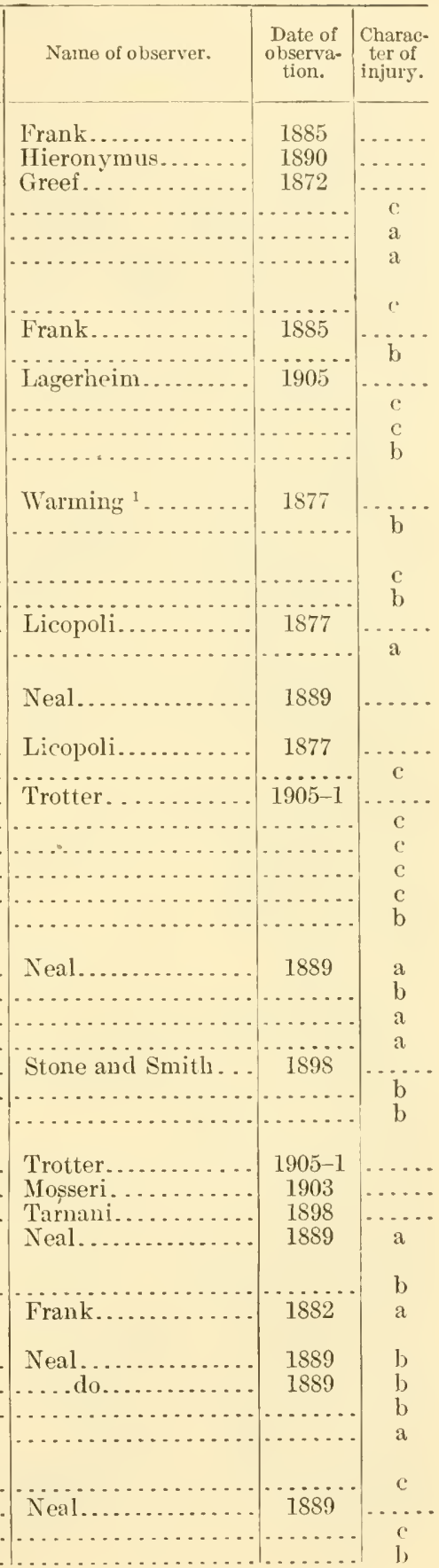

1 According to Ritzema Bos (1900-1) this injury is due to another nematode, Tylenchus hordci. 2 Species distinct from the preceding.

91294ํ-Bul. 217-1] —2 
TABLE I.-List of plants susceptible to root-knot-Continued.

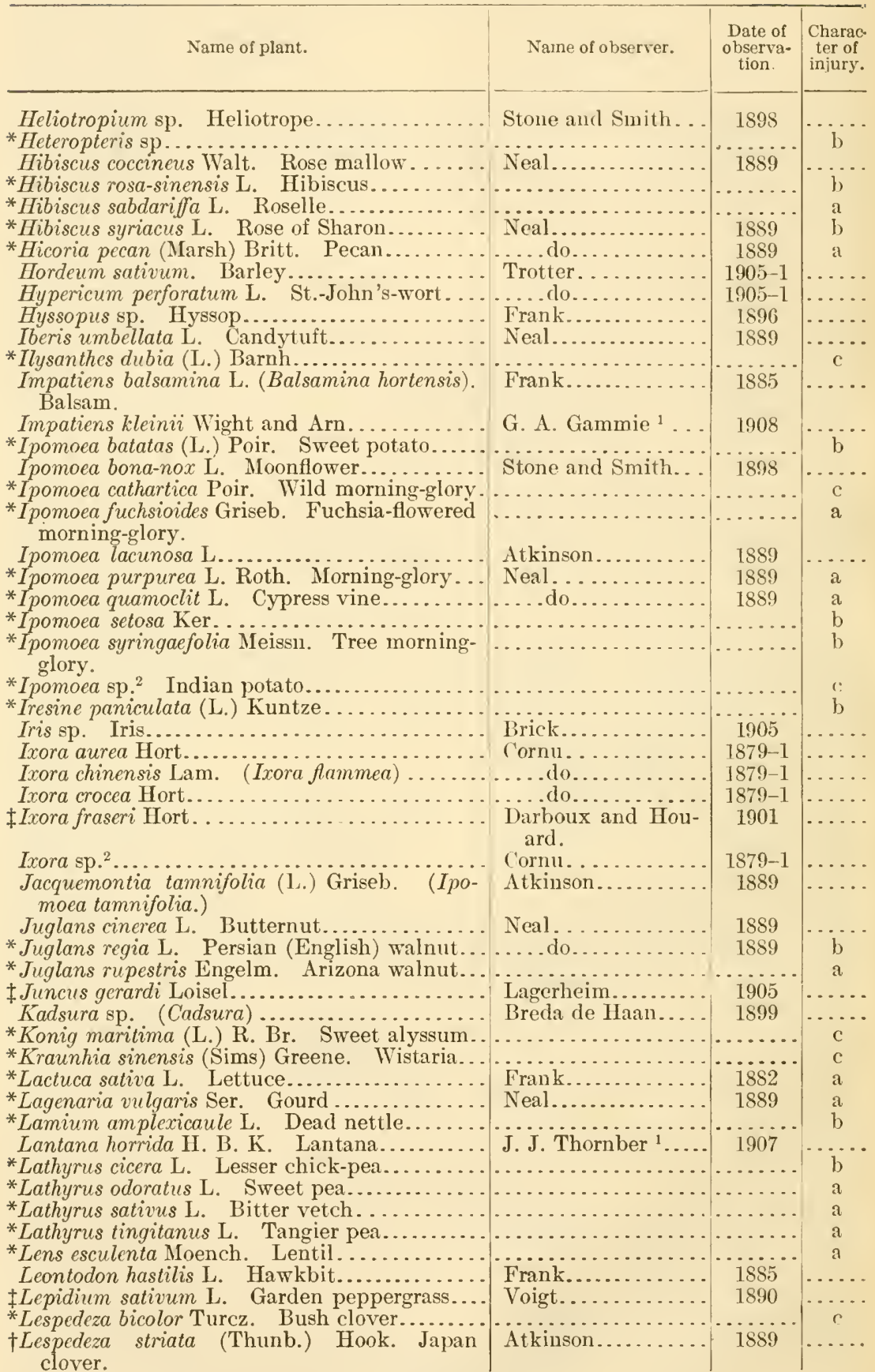


TABLE I.-List of plants susceptible to root-knot-Continued.

-

Name of plant.

* Ligustrum ovalifolium Hassk. California
privet.
* privet.

Linum angustifolium Huds.................

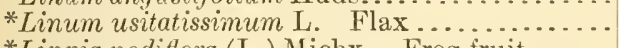

* Lippia nodiflora (L.) Michx. Frog-fruit.......

* Lonicera japonica Thunb. Japanese honeysuckle.

*Lotus corniculatus L. Bird's-foot trefoil.....

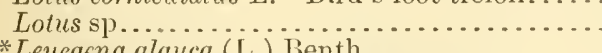

* Luevena glauca (I.) Benth ..................

* Luffa cylindrica (L.) Roem. Sponge gourd...

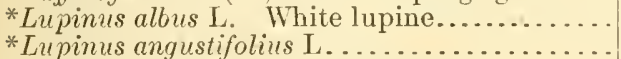

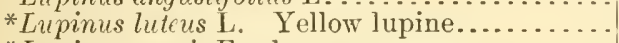

*Lupinus termis Forsk.

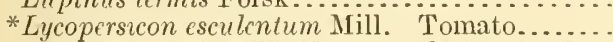

Malus sylvestris Mill. (Pyrus malus). Apple.

* Malva rotundifolia borcalis (Wallm.) Masters. Wild mallow:

* Manihot utilissima Pohl. Cassava.......... . .

* Ifarrubium vulgare L. Horehound..

* Medicago satiza L. Alfalfa, or lucern.......

$\dagger$ Meibomia mollis (Vahl) Kuntze. Florida beggarweed.

* Merbomia stricta (Pursh) Kuntze.

* Melia azcdarach L. Umbrella tree.

* Mclilotus alba Desr. White sweet clover, or Bokhara clover.

* Mclilotus indica (L.) All...

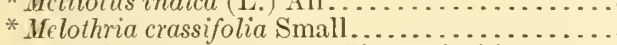

Mesembryanthemum sp. Fig marigold.

Modiola caroliniana (L.) Don. ( 1. multifida).

Mollugo pentaphylla L. (M. stricta).

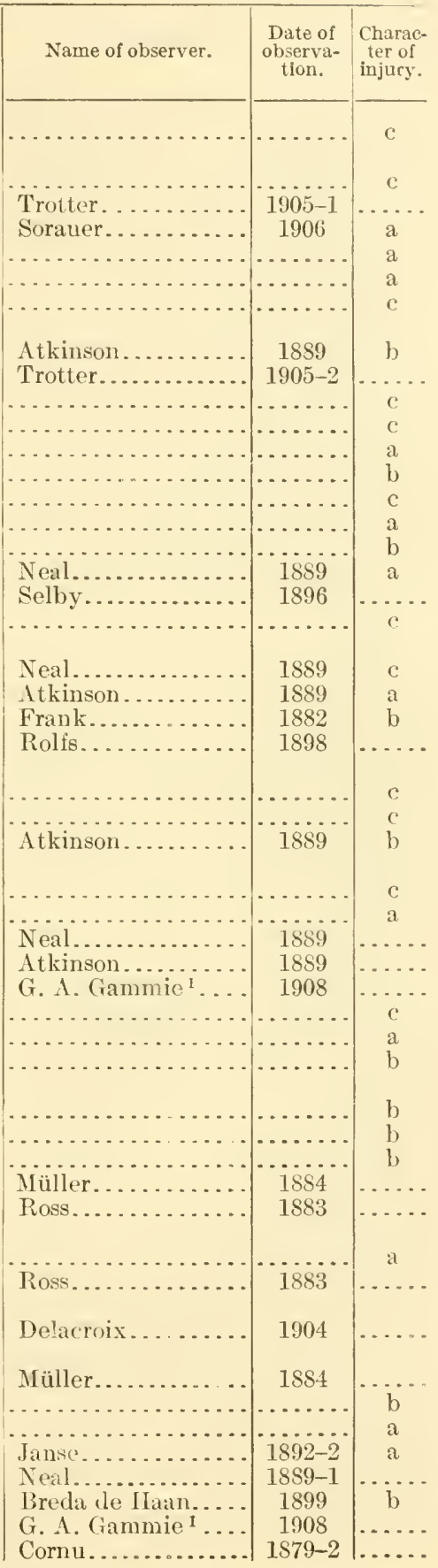

* Mollugo verticillata L. Carpet weed........

* Momordica charantia L. Balsam apple........

* Morus alba multicaulis (Perr.) Loud. IIfulberry.

* Morus alba tatarica (L.) Loud. Mulberry....

* Morus nigra L. Mulberry..................

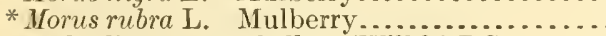

Mulgedium macrophyllum (ivilld.) DC ..........

Musa cavendishii Lamb. (Musa chinensis). Dwarf banana.

* Musa éssete Gmel. Bruce's banana.........

Musa paradisiaca dacca (IIoran) Baker (iI. dacca). Dacea banana.

Musa paradisiaca sapientum (L.) Kuntze. Banana.

Musa rosacea Jacq

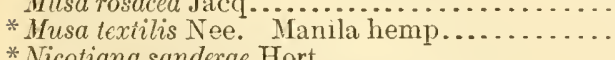

* Nicotiana sanderae Hort.....................

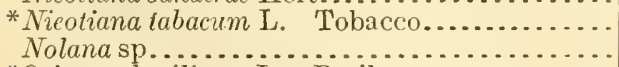

* Ocimum basilicum L. Basil....................

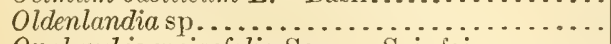

Onobrychis viciaefolia Scop. Sainfoin......... 
TABLE I.--List of plants susceptible to root-knot-Continued.

\begin{tabular}{|c|c|c|c|}
\hline Name of plant. & Name of observer. & $\begin{array}{l}\text { Date of } \\
\text { observa- } \\
\text { tion. }\end{array}$ & $\begin{array}{l}\text { Charac- } \\
\text { ter of } \\
\text { injury. }\end{array}$ \\
\hline rnithopus sativus Brot. Seradella & & & c \\
\hline xalis corniculata I. Sheep sorrel. & & & c \\
\hline Oxalis stricta L.................... & Tarnani.. & 1898 & \\
\hline * Paconia sp. Peony * Paliurus spina-Christi & & & $\mathrm{a}$ \\
\hline *Panax quinqucfolium L. Ginseng............. & Van Hook. & 1904 & a \\
\hline 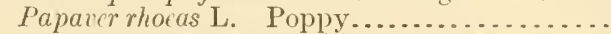 & Tarnani... & 1898 & \\
\hline 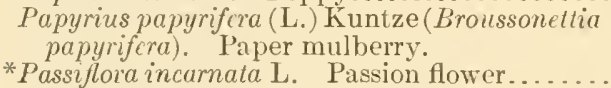 & Neal... & 1889 & \\
\hline * Passiflora pfordti ( $=\times$ P. alato-caerulea Lindi.) & & & a \\
\hline & Magni & 1888 & \\
\hline * Pastinaca sativa L. Parsnip... & Atkinson. . & 1889 & c. \\
\hline * Pclargonium zonale (L.) Ait. Gera & & & b \\
\hline * Pentagonia physalodes (L.) Hiern..; & & & b \\
\hline * Perilla frutesecns (L.) Britt. Perill & & & $\mathrm{b}$ \\
\hline †Persea gratissima Gaertn. f. Avocado.. & Lavergile & 1901 & \\
\hline *Petroselinum sativum Hoffm. Parsley.. & & & $\mathrm{c}$ \\
\hline $\begin{array}{l}\text { * Phaseolus aconitifolius Jacq. Aconite-leaved } \\
\text { bean. }\end{array}$ & & & b \\
\hline $\begin{array}{l}\text { * Phaseolus angularis (Willd.) Wight. Adsuki } \\
\text { bean. } \\
\text { *Phaseolus calcaratus Roxb. Seeta bean....... }\end{array}$ & & & a \\
\hline * Phaseolis lunatus L. Lima bean............ & Neal... & 1889 & b) \\
\hline * Phaseolus max L. Green gram, or mung bean . & & & b \\
\hline *Phaseolus radiatus L. C & & & b \\
\hline usus Moench. Mletcalfe bean... & & & a \\
\hline *Phaseolus vulgaris L. (incl. P. nanus). Bean. & Neal. & 1889 & b \\
\hline Physalis peruviana L. Cape gooseberry...... & ( P. Lounsbury ${ }^{1}$ & 1908 & \\
\hline 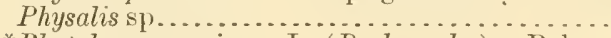 & Atkins & 1889 & \\
\hline $\begin{array}{l}\text { *Phytolacca amcricana L. (P. dccandra). Poke- } \\
\text { weed. }\end{array}$ & ..... do... & 1889 & b \\
\hline $\begin{array}{l}\text { * Pilea serpyllifolia (Poir) Wedd. Artillery } \\
\text { plant. }\end{array}$ & & & c \\
\hline Piper betle L. Betel pepper................ & Zimmermann & $1900-2$ & \\
\hline Piper nigrum L. Peppe & Delacroix.... & $190 t$ & \\
\hline rentosa (Willd.) H. B. K. & & & $\mathrm{b}$ \\
\hline$s c$ L. Field pea......... & & & c \\
\hline${ }^{*}$ Pisum sativum L. Garden pea............. & Ne: & 1889 & b \\
\hline $\begin{array}{l}\text { * Pithecolobium saman (Jacq.) Benth. Rain } \\
\text { tree. }\end{array}$ & & & a \\
\hline Plantago lanceolata I. Rib-grass.......... & Licon & 1877 & \\
\hline Plantago major L. Plantain....... & Frank. & 1885 & \\
\hline Plane tree. & & & c \\
\hline Plane tree & & 1906 & \\
\hline $\begin{array}{l}\text { Plectranthis sp....... } \\
\text { *Pluchca purpurascens }\end{array}$ & Frank............ & 1885 & \\
\hline * Pluchea purpurascens & & & a \\
\hline Cape leadwort. & & & b \\
\hline Poa annua L. Annual bluegrass & & 1872 & \\
\hline$\ddagger$ Poa pratensis L. Kentucky bluegrass......... & & 1898 & \\
\hline $\begin{array}{l}\text { Podranca ricasoliana (Tanf.) Sprague (Te- } \\
\text { coma mackcnnii). }\end{array}$ & C. P. Lounsbury ${ }^{1}$. & 1908 & \\
\hline rt... & Breda de Haan.... & 1899 & \\
\hline & & & \\
\hline Polygonum sp................................. & & 1898 & \\
\hline
\end{tabular}


TABLE I.-List of plants susceptible to root-knot-Continued.

Name of plant.

Name of observer.

* Portulaca olcracca L. Purslane...

tPrimula auricula L. Primrose.

+Primula carniolica Jacq. Primrose.

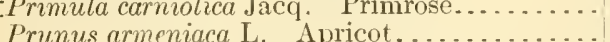

Prunus armeniaca $\mathrm{L}$. A

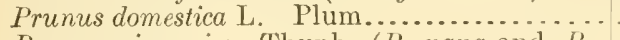

Prunus japonica 'Thunb. ( $P$. nana and $P$. lanceolata).

* Prunus virginiana L. Choke cherry.

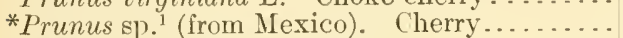

*Psidium guajara L. Guava.......

*Punica granatum L. Pomegranate...........

Pyrus conmunis L. Pear.................

Quercus suber. Cork oak..................
* Radicula armoracia (L.) Robinson. Horse-

* Radicula

* Radicula walteri (Ell.) Greene.

* Raphanus sativus L. Radish.

* Reseda odorata L Mignonette ............

$\ddagger$ Rhinanthus cristagalli $\mathrm{L}$. Rattlebox.

$\ddagger$ Ribes rubrum L. Currant.

* Rosa clincnsis manetti Dippel. Manetti rose.

* Rosa laevigata Michx. Cherokee rose........ .

* Rosa setigera Michx. Rose..................

Rosa sp. Rose.

Rubusidaeus L. Raspberry..............

Rubus subuniflorus Rydb.(R. villosus). Blackberry.

Rubus trivialis Mich...

* Rumex acetosa L. Sorrel.

*Rumex sp. ${ }^{1}$ Dock.

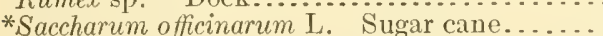

Salix babylonica L. TVeeping willow..........

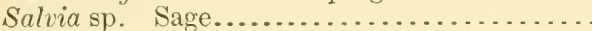

tSanicula europaea L. Wood sanicle ........

Scabiosa columbaria L........................
Schizonotus sorbifolius (L.) Lindl. (Spiraea sorbifolia).

* Scolymus hispanicus L. Spanish oyster plant.

* Scorzonera hispanica L. Black salsify .......

Sedum (several species)...................

Sempervivum glaucum Ten.

* Sempervivum tectorum L......................

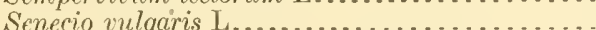

* Sesban bispinosa (Jacr.) Stend.

* Sesban macrocarpa Muhl..................

Sesuvium maritimum (Walt.) B. S. P. (S. pentandrum).

* Sesuvizem portulacastrum L.

* Sida rhombifolia L.

* Smilax glauca Talt...

* Solanum carolinense L. Horse nettle......

Solanum dulcamara L. Bittersweet.........

*Solanum melongena L. Eggplant........... . .

*Solanum nigrum L. Nightshade.............

* Solanum rostratum Dun. Buffalo bur.......

* Solanum tuberosum L. Potato.

Neal.................
Neal.

Dalla Torre.......

... do ...........

Neal ............

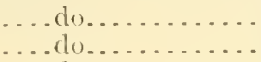

... do.............

. . . . . . . . . . .

(...........

Frank...............

Ducomet..........

..................

Neal. ................

Darboux and IIouard.

Cobb.

.......................

IIalsted... . . . . . .

Selby...............

Neal..............

do.

......to..............

Breda de Haan ....

Neal..............

Frank...........

Cornu. . . . . . . . . .
Sorauter. . . . . .

Neal.............

................

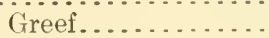

Licopoli...........

Trotter...............

1889

1882

1908

1889

1901

1901

...... $b$

1

1591

1896

1889

1889

1899

1899

1896

$1879-2$

1906

1889

1872

1877

1875

$1905-1$

.........................

Atkinson...............

iss9

(10..................

Mosseri......... 1903

Atkinson............. 1889

$1889 \quad$ a

................. c

Neal............. 1889 b

$\mathrm{a}$

Character of

injury. b

.....

$\ldots . .$.

-...

$\ldots .$.

....

c

a

b

a

$\ldots$

b

C

b

...

‥

b

....

$\ldots$

$\ldots$

b

b

....

$\ldots .$.

....

a

.....

C

C

b

b

c

$\mathrm{c}$

$\mathrm{a}$
$\mathrm{c}$ 
TABLE I.-List of plants susceptible to root-knot--Continued.

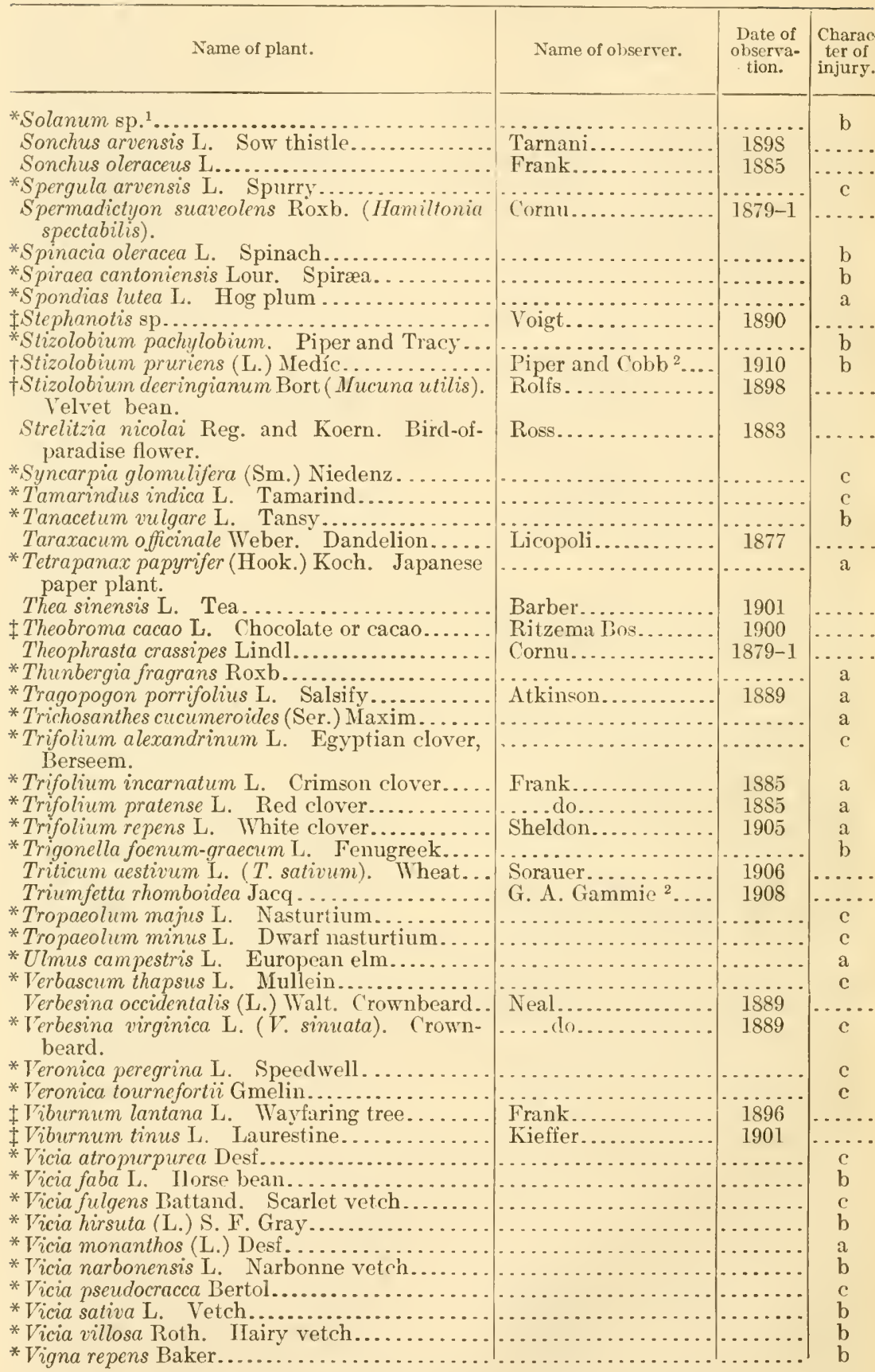


TABLE I.-List of plants susceptible to root-knot-Continued.

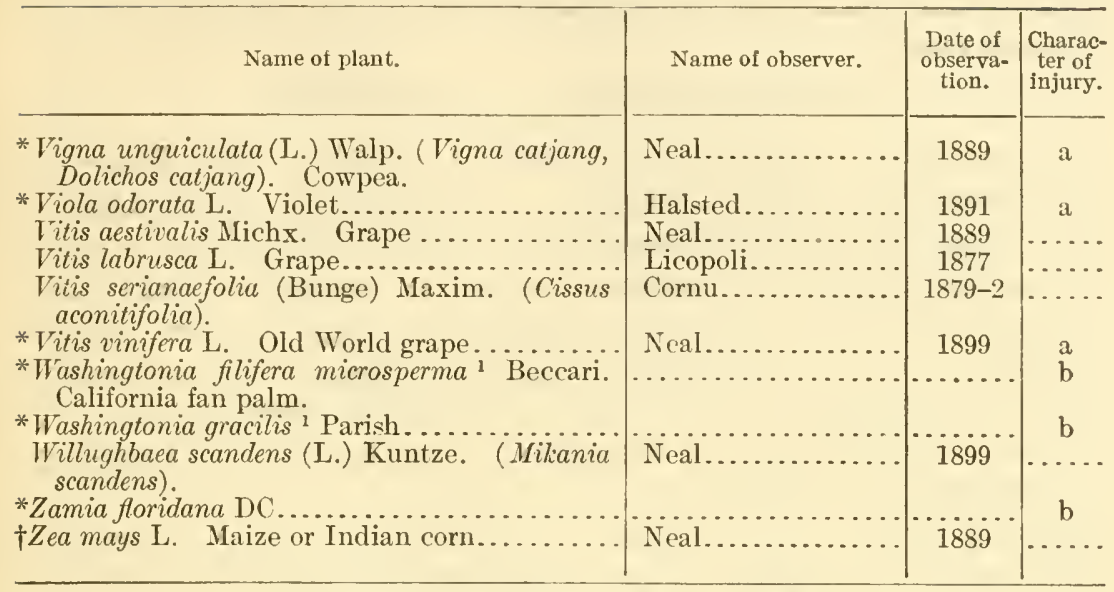

1 Seed received under this name from Dr. O. Beccari.

\section{PLANTS NOT AFEECTED BY ROOT-KNOT.}

Among the plants grown by the writer in infected land without their becoming infected with root-knot in tlie slightest degree were several species of Stizolobium, the genus to which the velvet bean belongs, viz, Stizolobium lyoni, S. pruriens, S. hirsutum, and the velvet bean and one or more other unidentified species of this genus. ${ }^{1}$ Many of the grasses seem to be resistant. Thus the writer has failed to find the nematode on crab-grass (Syntherisma sanguinalis), redtop (Agrostis alba), Johnson grass (Andropogon halepensis), some varieties of oats (Avena sativa)--but some are susceptible-Bromus schraderi, Eustachys petraea, some varieties of barley (Hordeum vulgare), Lolium perenne, Japanese barnyard millet (Echinochloa frumentacea), broomcorn millet, or proso (Panicum mitiaceum), pearl millet (Pennisetum sp.), timothy (Phleum pratense), rye (Secale cereale), the various forms of sorghums, milos, Kafir corn, etc. (Andropogon sorghum), wheat (Triticum aestivum), but see list of susceptible plants. The same is true of corn (maize, Zea mays) as of wheat. Euchlaena luxurians was also free. Several Compositæ seem to be free from the trouble even where the nematodes are very abundant in the soil. Thus, Bidens leucantha and B. bipinnata always were found free. Gnaphalium purpureum, Helenium tenuifolium, species of Solidago, Zinnia, etc., were also free. The absence of nematodes in the plants above enumerated is far less significant than their presence in other plants, for conditions may have been unfavorable, and yet under other con-

1 Rolfs, however, 1898, reports root-knot on the veivet bean, and recently Prof. C. V. Piper has found it in abundance on plants of Stizolobium pruriens, S. P. I. 21566, grown in a greenhouse in Washiugton, D. C. Evidently under certain conditions some strains may be susceptible, but as a rule it is immune. 
ditions they might have shown root-knot. However, it is probable that the above-named plants will show themselves nematode resistant in most cases.

\section{CROSS-INOCULATION EXPERIMENTS.}

It has been suggested by several investigators that Heterodera radicicola, like Tylenchus dipsaci, may show the development of strains preferring certain hosts and exhibiting a reluctance to attack others, although these different strains are morphologically indistinguishable. This explanation has been suggested for the fact recorded by Stone and Smith ${ }^{2}$ that lettuce often is not attacked in beds in greenhouses where other crops suffer great injury. The writer accordingly made a number of cross-inoculation experiments to determine, if possible, to what extent the nematodes of certain generally grown crops were interchangeable. The experiments were performed as follows: Pots of soil were sterilized in an autoclave for about an hour and a half, sometimes longer, at a temperature of $125^{\circ} \mathrm{C}$. While this was perhaps not long enough to kill all bacterial spores in the center of the pots, the temperature attained showed itself to have been high enough to kill all nematode larva or eggs. In the sterilized soil were placed affected roots of the plant used as a source of the nematodes. These roots were first carefully washed (sometimes in water containing a small amount of formaldehyde) to remove all adhering dirt in which conceivably larvis or eggs of other strains of nematodes might be present. These pots were planted with seeds of plants to be tested as possible hosts of the nematode, either at the same time or a few days after the roots were put into the pots. Except when it was certain that the water was nematode free, it was boiled and cooled before using it to water the pots. Experiments made in this manner showed that the root-knot nematodes were mutually interchangeable in the following plants: Red clover (Trifolium pratense; Pl. III, fig. 2), white clover (T. repens), crimson clover ( $T$. incarnatum), cowpea (Vigna unguiculata), strawberry (Fragaria chiloensis), tree morning-glory (Ipomoea syringaefolia), sunflower (Ilelianthus debilis), horse bean (Vicia faba), ginseng (Panax quinquefolium), purslane (Portulaca oleracea), fig (Ficus carica), papaya (Carica papaya), catalpa (Catalpa speciosa), tomato (Lycopersicon esculentum), and Old World grape (Vitis vinifera). These all also affect the following, for which the reverse inoculation experiments were not made: Lettuce (Lactuca sativa), green gram (Phaseolus radiatus), tobacco (Nicotiana tabacum), squash (Cucurbita moschata), cucumber (Cucumis sativus), and muskmelon (C. melo).

\footnotetext{
1 Prof. J. Ritzema Bos (1900) reports that Tylenchus dipsaci becomes so adapted to a host plant after growing on that species only for several generations that it will not attack with any severity the species upon which it grew before until several generations have passed.

2 Stone and Smith, 1898 , p. 30.
} 
The various families of plants represented in the foregoing list and the fact that the infections were obtained easily and very pronouncedly would seem to indicate that the nematode causing root-knot of the plants experimented with, including some of those most generally affected in the field, is not as yet very markedly differentiated into strains peculiar to certain hosts. It is still possible, and indeed quite likely, that had seeds of the same host as that furnishing the roots from which the nematodes came been sown in the pot along with the other seeds the latter would have shown less infection than the other plants. Unfortunately, however, various circumstances prevented this line of experiments from being carried out.

Observations in the field seem to bear out the results of the pot experiments. The writer has been unable to detect any special adaptation to any one species of plant. Indleed, peaches were attacked very badly when planted where cowpeas had been grown for several years. Figs and the Old World grape are the plants through which the parasite has been introduced into many new districts, which could hardly have been done so thoroughly and rapidly if the nematode had become in a manner specialized upon them.

\section{DISTRIBUTION OF ROOT-KNOT.}

Root-knot was first observed by Berkeley ${ }^{1}$ on greenhouse plants in England [t was next reported by Greef ${ }^{2}$ on out-of-doors plants in Germany. Sinee then it has been observed in many parts of Germany, France, Italy, Austria, Itolland, Sweden, and Russia. In Africa it is abundant in parts of Algeria, occurring even in some of the Saharan oases, Egypt, German East Africa, Transraal, Cape Colony, and Madagascar; in Asia it oceurs widespread in India, Ceylon, and to some extent in China and Japan. In the East Indies, Java and Sumatra are badly infested. No authentic reports have been reeeived of the presence of this pest in the Philippines, but it is probably to be found there. Several of the Australian States are infested, and the pest is not unknown in New Zealand. In South America it has been reported from Chile, Argentina, and Brazil. It seems also to be widespread throughout the West Indies. In Mexico it is prevalent at many points.

In the United States the root-knot is to be found in sandy soil now or previously in cultivation in most parts of North Carolina, South Carolina, Georgia, Florida, Alabama, Mississippi, Louisiana, and Texas, as well as at many points in California. It is not abundant in New Mexico or Arizona, although proving destruetive in some of the irrigated districts of the latter. It is very evidently of recent introduction there, as in many parts of Texas. In the interior of the 
West the writer has observed it, only sporadically it is true, in Utah and Colorado and at one place in Nebraska. It is reported, and the writer has seen specimens, from Arkansas. Olklahoma, Tennessee, and Kentucky have no reports of it in the open, but it is probably present to some extent, since it is found along the Ohio River in West Virginia and also in northern Pennsylvania. It occurs, but not in great abundance, in Delaware, Maryland, and Virginia The New England States appear to be almost free from the trouble, so far as outdoor plants are concerned, although it has been observed in Connecticut and Rhode Island. The most northerly points where it has been observed out of doors in this country are at various points in New York State, on ginseng and alfalfa; northern Indiana; Menominee, in the Upper Peninsula of Michigan; and the locality in Nebraska already mentioned. In the last three inst ances all the evidence indicates that the disease was directly imported from other localities and was not indigenous to that locality. 'The important point is, however, and this will be reverted to, that this nematode is able to maintain itself in regions where the winter's cold may be very intense

All of the localities named above are those in which the root-knot nematode has been found out of doors, not merely on plants partially protected during the winter, but in soil not at all protected from the severest winter cold. In addition to these localities it is almost universally present in this country in greenhouses and has in a number of instances become more or less established out of doors in their immediate vicinity, where it is protected by compost heaps, etc., from the extreme cold. In the most northern States it need not be feared that the pest will ever become widely distributed.

A careful study of the distribution of the disease convinces the writer that root-knot is of comparatively recent introduction in the regions west of the Mississippi. Indeed, it is possible to trace its arrival in parts of Texas, Arizona, and southern California, it having appeared in recent years after the land had been in cultivation for a long time with no signs of injury from such a pest. In Texas the introrluction and spread of the nematode has been accomplished almost entirely by means of infected nursery stock, mainly figs, mulberries, and peaches; in Arizona and California figs and the Old World grape seem to be the responsible plants. The scattered localities in the North where the trouble occurs often reveal, on careful inquiry, the source of the infestation. Ginseng has been responsible for several outbreaks, the nematodes doubtless having been introckuced in the moist earth in which the seeds were packed. In other cases nursery stock, such as peaches or even apples, has been responsible; sometimes the soil thrown out from greenhouses has 
spread the trouble, and in some cases the manner of introduction can not be determined.

Close analysis of all the earlier reports and of the existing distribution of root-knot has convinced the writer that we have to deal with a pest originally tropical or subtropical in its distribution and not native to any part of the United States. In this the writer comes to a conclusion at variance with that of Neal, ${ }^{1}$ who believed that it was native to the Southern States. If that were the case, however, it ought to be found on uncleared land where no crops have ever been grown, but that is not generally the case. Indeed, it is the general practice, when nematode-free land is needed, to go to uncleared land. To be sure, nematodes are occasionally found in such land, but almost always it can be shown to have been previously in cultivation, perhaps many years ago, or to be so situated that soil from infested fields could be washed upon it.

The general trade in exotic plants which began over a hundred years ago and grew rapidly, in the course of which ornamental and useful plants from the Tropics, especially of the Americas, were carried to European conservatories and gardens and also to our shores, may very probably have served to introduce the pest into the temperate regions of both the Old World and the New World. In all likelihood the Spaniards introduced this nematode into Florida directly from the West Indies or Central America, for it is found in parts of southern Florida that were in cultivation more than 75 years ago, but where now dense forests have grown up, as well as in clearings with no signs of recent cultivation. Yet even here it does not seem to occur in land absolutely unused in the past.

Whether the old World or New World Tropics were the original home can not be decided now, as it is widely distributed in both. Perhaps its wide distribution in Africa, India, the East Indies, China, and Japan and the fact that another species of the same genus (Heterodera schachtii Schmidt) is apparently native in Europe would warrant the conclusion that it is probably of Old World origin.

\section{THE CAUSAI PARASITE.}

Upon breaking across a medium-sized or large knot and holding the broken surface so as to reflect the light a close observer will often see one to many clear to almost pearly white rounded bodies, considerably smaller than half the diameter of a pinhead, projecting from the surface. With a hand lens they are easily seen, but for the unaided eye they are sometimes very difficult to detect, on account both of their minuteness and of their transparency. In knots that have been cut across they are usually not visible, as they col- 
lapse when touched by the knife. These objects are the mature females of the nematode Heterodera radicicola (Greef) Müller. Each is capable of laying several hundred eggs, more than 500 having been counted by the writer in one case where the nematode was still actively laying eggs.

EGG.

The eggs (Pl. I, figs. 1 and 2) are ellipsoidal bodies, sometimes symmetrical, more often slightly curved, and therefore somewhat kidney shaped. They are usually a little over twice as long as broad. Out of 71 different lots of egg masses measured by the writer, representing nematodes from 63 different hosts, the length varied from 67 to $128 \mu$ and the width from 30 to $52.5 \mu$. The greatest ranges observed in any one lot of eggs were 67 to 108 by 33 to $42 \mu, 88$ to 128 by 33 to $44 \mu, 81$ to 112 by 33.5 to $40 \mu$, and 84 to 119 by 35 to $52.5 \mu$. These represented in each case eggs from the same nematode, showing how variable in size they may be. The average range of all measurements was 85 to 98 by 34 to $40 \mu$ with an absolute average of more than 500 eggs measured of 92 by $38.4 \mu$. These dimensions agree closely with those given by Müller, ${ }^{1}$ who studied this nematode in Germany, his figures being 94 by $38 \mu$. On the other hand, Frank, ${ }^{2}$ also working in Germany, gives the figures as 80 by $40 \mu$. Stone and Smith ${ }^{3}$ give the length as $100 \mu$.

When the writer first examined the eggs from different hosts he thought that there might be a possibility of distinguishing different races of the nematode by the variations in the size of the eggs, but the variability in size, even among the eggs from the same nematode, soon demonstrated that no results of value could be obtained in this direction. It seemed to be true, however, that the smaller, less strongly developed females often produce the smaller eggs. Thus, a nematode situated near the surface of a root, where the pressure was not so great, was often larger and had larger eggs, but this rule has so many exceptions that it ean not be considered as being in any way general.

The egg consists of a densely granular body in which a lighter spot, the nucleus, can occasionally be seen, inclosed in a tough, elastic, transparent coat, or shell, probably chitinous in nature. When the mother nematode is so situated that she has plenty of room to deposit her eggs so that they are not laid with difficulty, they usually leave her body unsegmented. On the other hand, if the eggs as they are laid are crowded together so that considerable force has to be used to lay each egg, the oviposition is clelayed and segmentation begins before the later eggs leave the body. Only exceptionally, however, do the eggs develop so far as to contain fully developed 
larva by the time they are laid. Where this does occur it is mostly only the last eggs produced and which the mother nematode has not had the strength to force out against the large mass of eggs already laid. In this the root-knot nematode differs quite markedly from the sugar-beet nematode (Heterodera schachtii Schmidt), in which a comparatively large part of the eggs produced remain within the body of the mother and undergo segmentation and finally escape from the shell, eventually escaping to the outside through the openings in the body wall after the death of the old nematode.

Segmentation of the eggs begins very soon in any case and proceeds rapidly. It was not determined exactly how long the embryonic development required, but it is apparently not over two or three days in warm weather (much longer in cool).

The eggs were laid at the rate of 10 to 15 a day in the cases observed by the writer, although in some cases egg laying may proceed even more rapidly. They are surrounded by a slimy or gelatinous substance, which incloses them and evidently acts as a protection. This is secreted by the nematode with the eggs, as was observed on isolated mature females under the microscope. It is at first quite liquid and colorless, but soon becomes rather firm and light brown in color toward the outside. This is the structure that has been called by some investigators the egg sack (Eiersack); for example, Voigt ${ }^{1}$ and Strubell. ${ }^{2}$ The latter applied the term to the similar structure in the sugar-beet nematode (Heterodera schachtii), and, erroneously, denied its occurrence in $H$. radicicola. Occasionally the remains of the male may be found entangled in this slimy mass. It is probable in such cases that after fertilizing the female the male died and when the eggs were laid the egg mass surrounded his remains. The eggs at the outer portion of the mass are ustally either hatched or contain larvæ, while those next to the body of the nematode are not segmented.

This egg mass is sometimes as large as the adult female and can be seen readily when the latter partly projects from the root.

\section{LARVA.}

The larva (Pl. I, figs. 3 and 4) emerges from the egg through a hole which it pierces in the shell, usually at one end. It is a slender, cylindrical animal, blunt at the anterior and tapering at the posterior end to a pointed tail. The larvæ when they emerge from the egg are 375 to $500 \mu$ in length ${ }^{3}$ and about 12 to $15 \mu$ in greatest

1 Voigt, 1890.

2 Strubell, 1888.

${ }^{3}$ Stone and Smith (189s) give the length of the larva as $350 \mu$, but this is considerably less than the measurements made by the writer. They give the egg length as $100 \mu$, showing that they were not dealing with eggs below the normal size. 
thickness. The average length is 420 to $475 \mu$. The structure of the larva is comparatively simple, consisting essentially of a tube (the alimentary canal) within a tube (the body wall), the space between (the body cavity) being filled with a liquid and minor structures (fig. 1). The body cavity has no opening to the exterior. The alimentary canal opens anteriorly at the end of the body, but posteriorly it opens in the median ventral line about one-eighth of the dis-

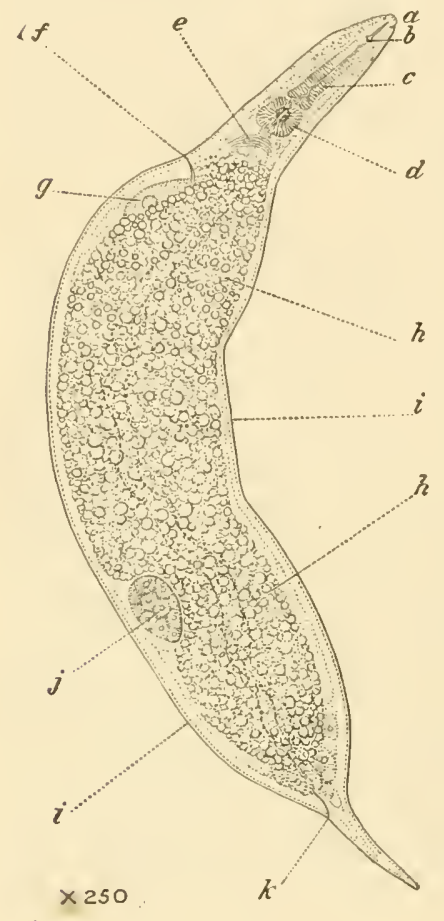

Fig. 1.-Hcterodera radicicola. Half-grown female (?) individual shortly before the final molt: $a$, Anterior end; $b$, spear; $c$, esophagus; $d$, esophageal bulb; $e$, nerve ring; $f$, excretory pore; $g$, gland; $h$, thick wall of alimentary canal; $i$, body wall; $j$, beginning of reproductive organs; $k$, anus. Magnified 250 diameters. Drawn by W. E. Chambers. tance forward from the tip of the tail (i. e., 50 to $65 \mu$ ). The body wall consists of an external cuticle and a dermal layer of cells beneath which are the four "fields" of obliquely longitudinal muscle cells. Longitudinal tissue masses springing inward from the dermal layer at the median, dorsal, ventral, and lateral lines separate tlie museles into the four "muscle fields" mentioned. Only occasionally the opening of the excretory canal can be made out in the larvin, but it is quite distinct in the mature male. It is in the ventral median line, opposite or slightly posterior to the esophageal bulb. These details of structure are clearly shown in the accompanying text figures (figs. 1, 2 , and 3), contributed by Dr. N. A. Cobb.

The alimentary canal consists first of a buccal spear (Pl. I, fig. 4) 10 to $15 \mu$ long (usually about $12 \mu$ ), a chitinous organ, pointed at the anterior end and with three small knobs at the posterior extremity and pierced its whole length by a fine canal. Connected with the basal knobs are retractile and exsertile muscles. This spear is used by the nematode in boring its way out of the egg and through plant tissues, and through it the nourishment is apparently drawn, for its canal is continuous with the lumen of the remainder of the alimentary canal. This spear lies in a cavity, the buccal cavity, from which it may be exserted. At the base of the spear begins the slender esophagus, 40 to $50 \mu \mathrm{long}$, which expands then into the thick, muscular-walled esophageal bulb (figs. 2 and 3 ). This is a stout, muscular body, often nearly spherical, but more often a little longer 
than broad, about 10 by $7 \mu$. The thick walls inclose a small lumen which can be expanded and contracted by the muscular action, thus acting in the manner of a pump in connection with the esophagus and spear (fig. 3). The expansion and contraction of the bulb are often synchronous with motions of the spear. Immediately behind the bulb the alimentary canal is rather narrow for a very short distance and then widens out rather abruptly into the comparatively thick-walled digestive portion which fills the body
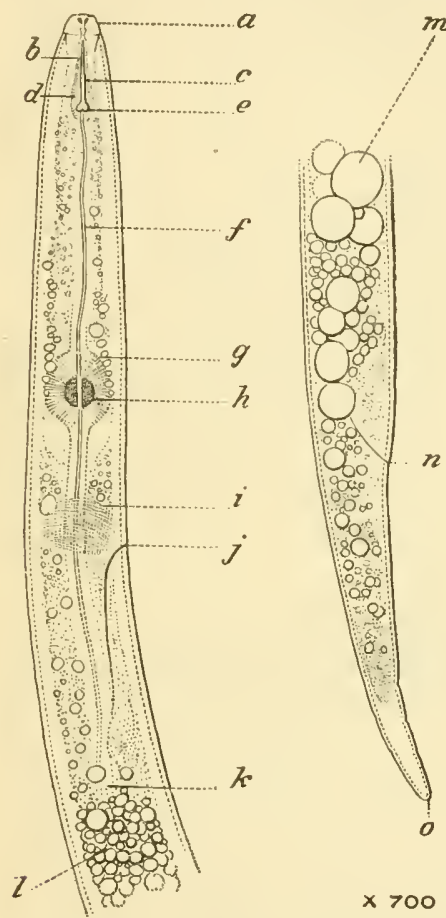

Fıg. 3.-Larva of Heterodera radicicolx: $a$, Anterior end; $b, c$, and $e$, spear; $d$, buccal cavity; $f$, esophagus; $g$ and $h$, outer and inner portions, respectively, of esophageal bulb; $i$, nerve ring; $j$, excretory pore; $k$ and $l$, lumen and thick wall, respectively, of alimentary canal; $m$, fat globule (?); $n$, anus; 0 , posterior extremity. Magnified 700 diameters. Drawn by W. E. Chambers.

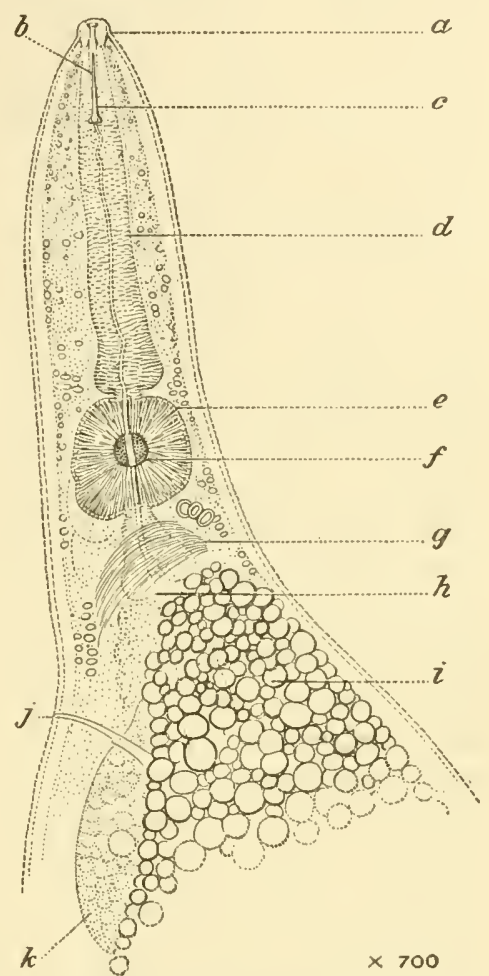

FIG. 2.-Anterior portion of the same nematode shown in figure 1: $a$, Anterior end; $b$ and $c$, free and inclosed portions, respectively, of spear; $d$, esophagus; $e$, outer wall, and, $f$, central portion of esophageal bulb; $g$, nerve ring; $h$, second bulb; $i$, thickened wall of alimentary canal; $j$, excretory pore; $k$, gland. Magnified 700 diameters. Drawn by W. E. Chambers.

cavity and continues unchanged to a point shortly anterior to the anus. The anterior part of this digestive portion is not clearly marked off as a second bulb, as is the case in some species of Tylenchus. Immediately behind the esophageal bulb, surrounding the short, narrow portion of the canal, can be seen occasionally the nerve ring. About 25 to $40 \mu$ anterior to the anus the walls begin to bocome thicker and the canal tapers, the anal opening itself being rather small. 
Except anterior to the digestive portion of the alimentary canal the body cavity is small. There are no signs as yet of the reproductive organs, nor can the sexes be distinguished.

The larvæ are actively motile, but not so active as many of the freeliving forms. Unlike the larræe of some nematodes parasitic upon plants, for example, Tylenchus tritici, ${ }^{1} T$. dipsaci, ${ }^{2}$ and a species of Aphelenchus discovered by Dorsett ${ }^{3}$ on the violet and studied by the writer, the larva of Heterodera radicicola are not very resistant to unfarorable conditions. The other nematodes mentioned are uninjured by desiccation for long periods, by cold, many acids, etc. Thus, the wheat nematode has been revived after having been left dry for 27 years. The $\Lambda$ phelenchus referred to remained alive in kerosene emulsion for two days in contact with a drop of kerosene. Osmicacid fixatives killed it but slowly, as was true of chromic acid, mercuric chlorid, and other strong poisons. On the other hand, the larve of Heterodera radicicola, although able to remain alive in water for a few days, soon die and decay, although damp or wet soil, provided the air supply is good, is favorable to their existence. Drying out is usually fatal to them in a comparatively short time.

The larva of the root-knot nematode are able to remain alive in the soil for months without entering upon a parasitic existence. The writer has been unable, however, to find any evidence that they take any nourishment from the soil; at least they undergo no development until they enter the roots of some plant, for if the soil be kept free from vegetation for two years they all die. Even one year without food is sufficient to kill large numbers of them.

In the normal course of development the larvæ, having encountered a root, seek its growing point and batter their way into it by the aid of the buccal spear (Pl. I, fig. 17). They then take up a position entirely within the root and parallel to its longitudinal axis, the anterior end pointing away from the root tip. This position may be in the plerome, or perhaps as frequently, if not more often, in the periblem. In the former case the nematode lies within the central cylinder as the root develops, in the latter case in the cortex. In either case the anterior end of the nematode is usually in close connection with the cells surrounding the conductive tissues. In the case of larvæ which hatch from eggs produced within the root, some bore their way out into the surrounding soil and enter new roots, as described above, while others burrow along in the tissues of the root and settle down, usually in the fleshy cortex. Thus an old nematode gall will contain nematodes in all stages of development and at a

1 Davaine, 1857. Münter, 1866. Needham, 1745, 1775. Baker, 1753.

2 Ritzema Bos, 1892.

( Dorsett, 1899. 
depth below the surface of the root of even 5 or more centimeters. The latter has been observed by the writer in roots of sweet potato (Ipomoea batatas) at Miami, Fla.

Within the tissues the larva becomes fixed in position and remains quiet except for occasional movements of the spear and esophageal bulb. Whether all the nourishment is taken through the hollow spear or some is absorbed directly through the skin was not determined. It seems probable, however, that the former is the case, especially in view of the fact that the female occasionally bursts the surrounding tissues of the root, so that she lies outside the latter except for the anterior portion, which remains buried in the tissues.

Growth begins almost immediately. This is mainly, however, in thickness and only slightly in length (Pl. I, figs. 5, 6, 7, and S). By the time a gain of 10 per cent in length has taken place the thickness has increased five to ten fold. This increase in thickness is confined to the region anterior to the anal opening and in the main posterior to the esophageal bulb. The alimentary canal posterior to the bulb becomes greatly enlarged. In a week or ten days the larvæ of both sexes are spindle shaped. By the end of the fifteenth to twentieth day the diameter is about a fourth of the length and the differentiation of the sexes becomes apparent (Pl. I, figs. 9 and 13). According to Stone and Smith ${ }^{1}$ the female nematode sheds her skin four or five times during the course of development, the first time just before leaving the egg and the other two or three times before the final molt, when she becomes sexually mature. The writer has been unable to confirm this statement. In none of the specimens examined was any sign of shedding the skin apparent on leaving the egg, although on this point the evidence is slight, as special attention was not given to it. On the other hand, no trace of old skins could be found surrounding the developing larvæ within the galls up to the time of differentiation of the sexes. It seems possible that the investigators referred to may have been misled by the fact that an injured nematode sometimes secretes a new cuticle underneath the old or on account of the circumstance that the molting may commence at one point long before it is visible elsewhere. If these extra molts do actually occur it seems strange that no signs are to be found of the cast-off skins around the nematode.

The writer's observations lead him to the following conclusions: The sexes are alike (externally at least) up to about the fifteenth day, or sometimes longer. Then a new skin becomes visible underneath the old, from which it becomes separated at various points. In the female the most marked change is that of the shape of the posterior end of the body, which no longer possesses the tail it had 
before the new skin was formed. At first the remnants of the old skin are visible as an empty skin attached to the rounded posterior portion of the nematode (Pl. I, fig. 9), but soon the growth of the latter obliterates the cavity left and all signs of it disappear. The anus, which before this time occupied a median ventral position some distance anterior to the tip of the tail, now becomes terminal, and immediately ventral to it but also occupying a position almost terminal on the rounded posterior portion appears the prominent genital opening, a horizontal opening with two rather thick and prominent lips (Pl. I, fig. 10). The anterior portion has undergone but little change. Apparently fertilization must take place at about this time, for soon the external genitalia become so modified that this would become impossible. The lips become smaller, the opening less prominent, and eggs begin to develop.

Up to the last molt the larvæ of both sexes are alike, at least externally. The writer's very numerous observations do not allow him to confirm the statement of Atkinson ${ }^{1}$ that the female can be distinguished before this period by the lack of a pointed tail, that of the male being pointed. In all the writer's observations, as previously described, the larvæ are indistinguishable until the last molt. Then the still small but sexually mature female may be seen, without a tail, in the old larval skin which has a tail.

\section{ADULT FEMALE.}

The mature female rapidly increases in thickness, becoming eventually flask shaped to pear shaped with a length of 400 to $1,300 \mu$ and a thickness at the point of greatest diameter of 270 to $500 \mu$, or even $750 \mu$ (Pl. I, fig. 12). The average of many measurements is about $800 \mu$ for the total length, $500 \mu$ at the point of greatest diameter, the length of the less enlarged anterior portion being $240 \mu$ and its diameter just before the region of great thickening begins $150 \mu$. This not greatly enlarged anterior portion usually extends to a little posterior to the bulb. The body then enlarges abruptly, this posterior portion being approximately spherical.

Up to the last molt the spear of the female retains the dimensions and shape it had in the larva. As is characteristic of all spearbearing nematodes, the old spear is shed with the cuticle at the time of molting, a new spear being formed in its place. This new spear is usually smaller both in length and thickness than the larval spear, and the knobs at its base are less prominent. It is usually 10 to $12 \mu$ long as against 12 to $15 \mu$ (rarely $10 \mu$ ), characteristic of the larva. 
The fully mature egg-laying female is of a glistening pearly white color. The enlarged posterior portion is smooth and shows no markings, except that the internal organs are visible where they approach the surface. The comparatively little enlarged anterior portion shows faintly the transverse cuticular markings so characteristic of the mature male.

The bulk of the body of the sexually mature but not yet egglaying female is occupied by the enormously dilated alimentary canal (Pl. I, fig. 11). The anus is a small round terminal opening, while the genital opening is a transverse slit slightly ventral to the anus and bordered by two more or less well-marked lips. This opens into a short, thick-walled vagina about 16 to $20 \mu$ in diameter (including the walls). At its upper end it is abruptly contracted into a tube 8 to $10 \mu$ in diameter, which soon divides into two tubes, the uteri. These are at first slender but slightly coiled tubes, leading forward (usually lateroventrally) and gradually increasing in diameter. Just before the ovary is reached each uterus expands into a spherical portion, about $16 \mu$ in diameter, apparently the receptaculum seminis. Above this lie the cylindrical ovaries filled with the rudimentary eggs in the form of a sort of parenchyma. At this time the whole reproductive system if straightened out would not be more than 300 to $400 \mu$ long. After fertilization the uteri undergo a most remarkable elongation and become very much coiled and tangled as they become filled with the fertilized ova. Although the body of the nematode increases rapidly in thickness, the increased space thus afforded is not sufficient, the alimentary canal becomes pushed to one side, and much of the space originally occupied by it is occupied by the uteri.

Egg laying had already begun, in the earliest cases observed by the writer, 29 days after the seed of the host plant (Pisum sativum, the garden pea) in these experiments was planted in soil known to be infested with the nematodes. Since germination of the seed is not immediate it is probably safe to assert that during warm weather the period from the time the larva enters the root until it begins egg laying is not over 25 days. This is somewhat longer during cooler weather, i. e., in the early spring and in autumn.

In most cases the greater part of the eggs are laid in an unsegmented condition. However, if the nematode is buried deeply in the tissues so that their pressure impedes egg laying, the eggs may develop and the larvæ escape still within the body of the mother, so that the latter may be viviparous. The last few eggs often develop in a similar manner, the nematode having evidently become so weak that she could not deposit them before they underwent development. 
MALE.

The development of the male after the larval stage differs greatly from that of the female. Within the old larval cuticle a new cuticle is formed. The nematode pulls itself away from the old skin, remaining inclosed by it, however. The tail is rounded here, too, but the anus is rentral instead of terminal. The whole body now elongates very rapidly, becoming correspondingly slender (Pl. I, figs. 13 and 14). This necessitates a coiling in order still to remain within the old skin, until it is coiled two or three times. When this development is complete (Pl. I, fig. 15) it breaks its way out of the old cuticle, which has retained its larval shape, and passes through the tissues and probably even outside of the root in search of a female. Just prior to leaving the old larval skin after undergoing this metamorphosis the nematode does not molt again, as some assert.

The mature male differs greatly in many particulars from its appearance just previous to the last molt. The form is about like that of the larva on emerging from the egg, i. e., long and slender, differing, however, in the greater size and in the short, rounded tail. The length is usually 1,200 to $1,500 \mu$, the thickness 30 to $36 \mu$. The tail is short and rounded, not tapering, the distance from the anal opening to the posterior end of the body being not more than 13 to $18 \mu$. The cuticle over the whole body is very distinctly marked with transverse rings extending entirely around the body and 2 to $2.5 \mu$ apart (shown in section in Pl. I, fig. 16). Except in profile it is only the furrows between the projecting segments of cuticle that are visible. These cuticular rings, which are also visible on the anterior portion of the mature female, are not visible, at least at ordinary magnification, in the larvæ.

The alimentary canal is essentially as in the young larva. The spear, however, deserves special notice. It is larger than in the larval stage or than in the mature female, being usually about $24 \mu$ in length (rarely as short as $18 \mu$ or as long as $28 \mu$ ). The knobs at its base are prominent. Above the knobs the sides are parallel for about half way and then taper to the finely pointed tip. The canal through the spear is rather distinct. The body wall is about $1.5 \mu$ thick. However, at the truncate anterior end it is between 5 and $6 \mu$ thick. The anterior $2.5 \mu$ of this is a sort of hood, or cap, set off from the rest of the body by a sharp furrow. Lying in the terminal body wall, well below this hood and projecting but slightly into it, is a series of six radiating perforated lamellæ (apparently chitinous in nature), narrow at their anterior ends and broad basally. Viewed from the side they are approximately right triangles, the hypotenuse being somewhat wavy. The bases of the lamellæ radiate from a 
common center, and the upright legs of the triangle surround a canal through which the spear passes. The bases are united into a small ring just around this canal and another ring unites the outer ends of the basal legs (Pl. I, fig. 16). Looked at from the anterior or posterior direction this apparatus resembles a wheel with six spokes. Distinct muscle strands run from the rim of this wheel to the knobs of the spear, as well as to the point where it begins to taper. It is probable that this peculiar organ is to help support and guide the spear as the male is battering his way through the tissues. A similar apparatus is present in IIeterodera schachtii, the sugar-beet nematode. It was imperfectly described by Strubell, ${ }^{1}$ but the writer's observation shows it to be essentially the same as in the root-knot nematode. It has also been reported, but not correctly described, for a Tylenchus species.

The reproductive organs of the male consist in all cases examined by the writer of a single testis, a tube blind at the anterior end and running parallel to the alimentary canal, into which it opens just before the anal opening is reached. Atkinson reports that there are two of these reproductive organs, as is the case with some other nematodes. In all the specimens examined by the writer, however, including specimens from Indiana, South Carolina, and Florida, using the oil immersion lens and viewing the nematodes from different sides, there was not the slightest evidence of a second testis. Cobb ${ }^{2}$ also mentions its presence, and as both he and Atkinson are accurate observers it must be that sometimes this occurs. In fact, Atkinson himself later found specimens in which the testis was single. ${ }^{3}$ According to the writer's own observation the right testis is the one that is missing, as the one present is placed somewhat asymmetrically, lying nearly in the left half of the body.

Lying on either side of the posterior portion of the alimentary canal and with their points entering the cloacal chamber are two peculiar, somewhat sickle-shaped bodies, the spicules. These are curved bodies, tapering toward the posterior end, about $35 \mu$ long, measured on the chord connecting the two ends. No accessory piece is present, although a thickening near the apical portion may represent one fuser with the spicules. These spicules are of use only during the sexual process.

The excretory canal is plainly visible in the left lateral line, opening ventrally in the median line 160 to $170 \mu$ from the anterior end of the body.

It seems probable that the mature males take little or no food and that they perish after having performed their function. The reason for this supposition is the fact that one often finds still actively 
moving males in which the alimentary canal posterior to the bulb, or even including it, has entirely disintegrated, leaving the body cavity filled with a granular disorganized mass except for the long testis, which extends nearly to the esophageal bulb. 'The large buccal spear with its complicated guiding apparatus is doubtless to enable the animal to batter its way through the root tissues in its search for the female, as a much smaller spear serves the female for obtaining the necessary food.

\section{OVERWINTERING.}

The stage in which this nematode overwinters was made the object of considerable study. In the galls on annual plants examined in November it was found that in almost all cases the mature or partly developed nematodes, as well as the eggs, were dead, in many cases being filled with fungous threads. Larvæ, however, alive and actively motile, were found in abundance in and around the galls. It is probable, therefore, that it is in the larval stage that the nematodes from annual plants pass the winter, probably descending into the lower levels of the soil to avoid the cold. This latter point, however, was not determined. In cases where the death of the top of the plant had caused the death of the roots, the nematodes in the roots soon died also.

In roots of peremnial plants, for example, European grape, fig, etc., the writer has repeatedly found living female nematodes in nearly or quite complete development at various periods in the winter and early spring, showing that in such roots the nematodes may survive not only in the larval stage, as previously described, but also as mature females ready to begin egg laying as soon as the weather becomes favorable.

\section{COMPARISON WITH HETERODERA SCHACHTII.}

In view of the fact that some authors ${ }^{1}$ have questioned the correctness of keeping separate the two species Heterodera schachtii, the sugar-beet nematode, and $H$. radicicola, the cause of root-knot, it will be well to give briefly an account of the points of difference, especially since the writer has found the former to be a scrious pest at several points in California and Utah, while the latter has been found as a serious sugar-beet pest at some other points. In tabular form the main differences are easy to point out. 
TABLE II.-Differences between Heterodera schachtii and H. radicicola.

\begin{tabular}{|c|c|c|}
\hline Points. & Heterodera schachtii. & Heterodera radiclcola. \\
\hline Effect on host........... & No galls. & Produces galls on roots. \\
\hline $\begin{array}{l}\text { Location of mature fo- } \\
\text { male. }\end{array}$ & $\begin{array}{l}\text { External, anterior end only within } \\
\text { tissues of root. }\end{array}$ & $\begin{array}{l}\text { Usually entirely within tissues of root, } \\
\text { more rarely the posterior portion, } \\
\text { very rarely nearly the whole body } \\
\text { external. }\end{array}$ \\
\hline $\begin{array}{l}\text { Shape of female, external } \\
\text { appearance, etc. }\end{array}$ & $\begin{array}{l}\text { Mostly lemon shaped, dull and flaky } \\
\text { in appearance, no trace of transverse } \\
\text { rings. }\end{array}$ & $\begin{array}{l}\text { Pear or flask shaped, glistening and } \\
\text { pearly white, transverse rings of } \\
\text { cuticle often visible on anterior por- } \\
\text { tion. }\end{array}$ \\
\hline Eggs... & Part deposited outside body, but most & All but the last few deposited outside \\
\hline Larva. & Buccal spear about $25 \mu$ (PI. I, figs. 18 & Buccal spear 10 to $15 \mu$, mostly 12 to $15 \mu$ \\
\hline & $\begin{array}{l}\text { and 19). } \\
\text { Buccal spear about } 30 \mu \text { (according to } \\
\text { Strubell, 1858). }\end{array}$ & $\begin{array}{l}\text { (Pl. I, figs. } 3 \text { and 4). } \\
\text { Buccal spear mostly about } 24 \mu \text {. }\end{array}$ \\
\hline
\end{tabular}

That these nematodes are not the same is readily seen when they occur on the sugar beet. The one causes no conspicuous galls while the other makes the galls so characteristic of root-knot (Pl. II, fig. 1). Both are very destructive pests of this host, and there is not much choice as to which is the more harmful. Another difference not mentioned above is that $H$. schachtii, perhaps by virtue of its more powerful spear, is able to thrive and spread in stiffer soils than does $H$. radicicola. In Plate I the figures for the larvæ of Heterodera radicicola (figs. 3 and 4 ) and $H$. schachtii (figs. 18 and 19) are drawn to the same scale, respectively. The difference between the two species was emphasized in tabular form by Voigt in 1890 .

\section{METHODS OF SPREAD.}

The larva of Heterodera radicicola is capable of active movement in the soil, and in this manner doubtless the disease is slowly spread. From some experiments made by Frank ${ }^{1}$ he estimated the rate of progress at about $3 \mathrm{~cm}$. per week. This would amount, during the warm weather, in which infection occurs, say May 1 to September 15 , to about $75 \mathrm{~cm}$., or about 30 inches. These figures are probably far too low. However, it is not through their own efforts that these nematodes are mainly spread. There are many means of transportation at their disposal. A very frequent one is running water. Thus, a field previously free from the pest sometimes shows its presence in those spots where surface water at a time of heavy rains has deposited a lot of soil from an infested field lying higher up. In this way the pest has been carried from infested fields even to uncultivated woods, as observed by the writer at one place. It has been suggested that heavy winds carrying large quantities of soil from one field to another may also transfer the nematodes, but in view of their susceptibility to injury by drying, this seems little likely. Especially is 
this unlikely since the larvæ shun dry soil, and so would not be present in that part of the soil which is dry enough to be transported by the wind. More effective as means of transportation are the hoofs of animals, wheels of vehicles, farm implements, and men's boots. It is difficult to see how it would be possible to avoid conveying living nematode larvæ from one field to another on farm implements if they are left, as is too often the case, uncleaned on being transferred from one field to the next. Thus, a wagon and horses going from one field to another would, if the soil were at all damp, carry some of the damp earth, probably containing nematode larvæ, with them.

The foregoing explains the spread of nematodes after they have once been introduced into a locality. The introduction of nematodes into a new locality, however, must have some other manner of accomplishment. This seems to be in most cases along with nursery stock. Thus, the writer found that in parts of Texas the nematode appeared first in the soil near fig and mulberry trees obtained from farther east, which were noticed at the time of planting, several years ago, to have knotted roots. In this way the soil near the trees became infested and thence the disease spread, as previously described, to different points in the locality. Perhaps east of the irrigated districts the fig, mulberry, and peach are responsible more than any other plants for the spread of the disease. Since the putting into effect of good nursery inspection much of this source of infection has been cut off. In the irrigated districts of Arizona and California the vine was observed in several cases to be the plant at fault. The strawberry has been observed at a few points in the East as the plant upon which the pest was introduced. It is often badly affected without showing much injury. A case has been called to the writer's attention in which the disease was introduced into a garden in Washington, D. C., by asparagus roots from an infested field. The wide distribution of the disease in ginseng plantations is doubtless due to the setting out of small rooted plants from infested regions, as well as to the practice of some growers of packing the seed in damp earth. Should this come, as is natural, from the vicinity of the ginseng bed and this be affected by nematodes, the danger of sending nematodes along with the seeds is very great. The dirt used for packing is naturally thrown out at the point where the seeds are planted, and thus the larvæ, if present, are able to enter the soil and infect the young ginseng seedlings. Seed potatoes are also another known source of introduction of the disease. ${ }^{1}$ In a personal communication Dr. N.A.

1 Lounsbury (1904) regards the potato as perhaps the chief source of introduction and spread of this disease in South Africa. 
Cobb expresses the same opinion based on his observations in New South Wales. ${ }^{1}$

For the North, where root-knot is mostly confined to greenhouses and hotbeds and their vicinity, perhaps one of the chief sources of infection is the soil that is thrown out of these beds at the end of the season. This soil, if infested, will spread the disease in the immediate vicinity, especially if it be put near some manure pile or compost heap which keeps the ground damp and warm during the winter.

\section{EFFECT ON THE HOST.}

The effect upon the root of the presence within it of the young nematode is usually the hypertrophy of some of the tissues. The parenchyma cells become abnormally large and multinucleate, ${ }^{2}$ sometimes only a few, at other times a great many cells being involved in this hypertrophy. This abnormal enlargement of the cells leads to a displacement of the various tissue elements, so that the tracheary cells and vessels become separated and also show lateral displacement and often much distortion. Often in bad cases individual cells of a tracheary nature will occur entirely separated from others of the same kind. The amount of hypertrophic enlargement of the root depends upon the host on the one hand and upon the number of nematodes entering the root in the same vicinity on the other. In some roots the swelling is barely noticeable and is so small that as the female nematode enlarges she eventually is inclosed in the root only by the narrow anterior third of the body, the remainder being entirely external, in this particular showing great similarity to the sugar-beet nematode, whose galls are always of this nature. More often, however, the hypertrophy is so pronounced that the mature female is entirely concealed or reaches the surface only at the extreme posterior portion of the body. If many nematodes are present in the same general region of a susceptible root, the gall may be many times the normal size of the root (Pl. II, fig. 2). These galls are at first of soft tissues, but in some woody plants, the European elm, for example, some of the hypertrophied cells become lignified, inclosing the female nematode in a woody prison from which in all probability the larvæ would be unable to escape should egg laying continue after the lignification las begun. The structure of such a gall is like that of the burls that often occur on various trees.

A very frequent phenomenon, but one that is by no means universal or characteristic of any one group of plants, is the formation of numerous lateral rootlets above the gall. This is doubtless due

1 The writer's attention has been called to the fact that in certain of the irrigated districts of the West this nematode has become a very serious potato trouble. On one occasion several carloads of potatoes were rejected on account of being infested with it.

2 Tischler, 1902. 
to the disturbed and to a large extent interrupted water supply and to the accumulation above the gall of food substances which would normally pass on to the root tip. They accordingly are made use of in the formation of lateral roots at that point. It is probably not different in its nature from the adventitious root formation in cotton and other plants just above the point of entry of the wilt fungus (Neocosmospora vasinfecta) ${ }^{1}$ or, in fact, from that occurring when the end of a root is cut off or mechanically injured. The shape or size of the gall does not seem to depend upon the place the plant occupies in the current schemes of classification. The statement of Frank ${ }^{2}$ that the galls of the dicotyledons are mostly of the round, tuberlike type, with lateral rootlets, while those of the monocotyledons are mostly spindle shaped, without lateral rootlets, is not confirmed by the writer's observations. Galls of both types may be found on the same plant (Pl. III, figs. 1 and 2) and appear to owe their differences to the number of nematodes entering at a given point, to the age and rapidity of growth of the root, and perhaps to other causes. On both the beet and the radish, as well as on many other plants, both types of galls and all gradations between may be found. Entrance to the plant by the larvæ is not confined to root tips or to passage from galls to the adjacent healthy tissues, although these are the usual ways by which a nematode reaches the point where it undergoes its subsequent development. Nematodes are also able to bore from the outside directly into the tender tissues of other parts of the roots, and even into stems. Thus, not only are the roots of potatoes attacked but even the tubers, while sometimes the prostrate stems of tomato plants as well as those buried beneath the ground in setting out the young plants are badly knotted. Indeed, Señor Romulo Escobar, of the Mexican Ministry of Agriculture, informs the writer by letter that in the State of Nuevo Leon the roots, stems, leaves, and even fruits of the watermelon are attacked when they are in contact with the ground. This is exceptional, however, and is possible only where the nematodes are very abundant and when the surface of the soil is constantly moist, so that they are in its uppermost layers.

Through the kindness of Mr. W. K. Winterhalter, then consulting agriculturist of the American Beet-Sugar Co., at Rocky Ford, Colo., analyses were made of sugar beets badly affected with root-knot and of healthy beets from the same field. Strange to say, in six samples each of healthy and diseased beets the average sugar content differed less than one-fifth of 1 per cent of the total weight of the beet, while the percentage of purity was equally as close in the two lots. In these points there also seems to be a marked dis- 
tinction between the root-knot nematode and the true sugar-beet nematode (Heterodera schachtii), for the latter's presence not only reduces the size of the affected beets, but also greatly reduces their sugar content and usually lowers also the purity.

The greatest depth at which Frank observed nematode galls was 33 centimeters (about 13 inches). On the other hand, the writer finds that they may occur more than a yard below the surface of the soil. To be sure, these are only scattering galls, for the great majority of the nematode galls occur in the first foot of the soil. Indeed, in practical culture it has been found that if trees can be forced to root extensively at a depth of 16 inches or more they suffer but little from root-knot.

\section{CONDITIONS FAVORING ROOT-KNOT.}

SOIL.

Root-knot is essentially a disease of light soils. Wherever the soil is sandy or contains a fairly large proportion of sand, other conditions being favorable, the root-knot nematode may be expected to thrive when once introduced. In heavy soils, on the other hand, the disease seems never to be serious. In some of the writer's experiments affected plants were planted in pots of stiff clay soils, and not only was it almost impossible to obtain infection of susceptible plants placed in close proximity in the same pots, but even on the diseased plants the new roots remained free from the trouble. Similar experiences have been reported to the writer from various parts of the country where diseased trees were set out in stiff soil and after a few years seemed to be entirely free from the trouble. Contradictory statements sometimes find their way into print, but they are explicable in most cases when one understands the great popular confusion in the use of the words "heavy," "stiff," and "light" as applied to soils. Thus, in parts of Florida and South Carolina a very sandy, yellow soil containing only enough clay to hold it together while moist, is called "clay" or "heavy soil." It is clayey, to be sure, compared with some of the soils thereabouts, for sometimes the latter are almost pure sand. "Light" and "heavy" in the sense used in this bulletin have reference to those soils containing, respectively, little and much clay. Soils that dry out rather quickly, that do not cake hard on drying, and that are easily crumbled to a fine granular mass are favorable to these nematodes, while the reverse is the case for the difficultly permeable, hard-caking, clayey soils. This applies only to the root-knot nematodes, as the writer's investigations have not gone into this point with reference to other sorts. It is known that the sugar-beet nematode will thrive in some of the heavier as well as in light soils. 


\section{MOISTURE.}

A certain degree of moisture is necessary for the maintenance of the life of the nematode in the soil. Experiments by the writer, Frank, ${ }^{1}$ and others have shown that the larvæ of the root-knot nematode, unlike those of many other nematodes, are destroyed by being dried in the laboratory. Observations by the writer in New Mexico, Arizona, and California confirm this abundantly, for in those communities the root-knot is practically confined to the irrigated land. This does not mean that the soil must be wet, for that is not necessary. The soil, however, must have sufficient moisture in it to be properly called a moist soil, though not enough to fill the air spaces and interfere with proper aeration. Thus, we have reports from South Africa, ${ }^{2}$ Argentina, ${ }^{3}$ and Chile ${ }^{4}$ which state that the nematodes grow only in wet soils. This, in the light of conditions existing in America, evidently means not what we would call wet, but merely moist, in the eastern and southern part of the United States, but what many people in irrigated districts would not hesitate to call wet in contradistinction to the dry, unirrigated soils. Prof. P. H. Rolfs, ${ }^{5}$ Dr. N. A. Cobb, and others report experiments which would seem to prove that drying of nematode-containing soil does not entirely kill out the Heterodera radicicola. This will be discussed more in detail later.

On the other hand, soils that are water-logged for a considerable part of each year are usually free from the trouble. Some observations on the effects of floods on nematodes led the writer to believe that flooding for a few days would destroy them, but field experiments in Arizona and California showed that keeping the soil submerged for five days was not sufficient to kill out the nematodes, at least not those inclosed within the root galls of the trees and vines growing in the fields. Yet it is certain that very wet soils are free where this is long continued, and long periods of flooding kill out the nematodes. Thus, in the Everglades of southern Florida there occur islands, parts of which are never flooded and parts of which are out of the water ordinarily, but submerged for two to six months of the year. Truck growers occupy some of these islands and find that the root-knot nematode is abundant above the high-water level-i. e., where the land is never flooded, but absent in the zone that is flooded every year.

\section{TEMPERATURE.}

As long as the soil is not too dry, the higher the temperature the more actively the nematodes seem to develop. On the other hand, they seem to become practically inactive when the soil temperature falls below $50^{\circ} \mathrm{F}$. Yet they are capable of remaining alive when

\footnotetext{
1 Frank, 1885. 2 Lounsbury, 1904. ' \& Huergo, 1902, 1906. ' Iavergne, 1901. ' Rolfs, 1894.
} 
exposed to great cold. The writer saw root-knot abundant on ginseng in a slat shed in Menominee, Mich., where the soil a year or so before froze to a depth of more than 3 feet and where outside the shed water pipes 6 feet beneath the surface were frozen, so the writer was informed. In spite of this cold the nematode injuries were bad the next year. In York, Nebr., where the temperature goes below zero every year and sometimes reaches nearly or quite to $-30^{\circ} \mathrm{F}$, this nematode survived the winter in peony roots which remained out of doors without protection. In New York State ginseng and alfalfa are both more or less affected with root-knot, while in West Virginia, along the Ohio River, clover is badly affected. It thus becomes apparent that cold alone does not destroy the pest in the soil. To be sure, Bailey ${ }^{1}$ placed soil containing root-knot nematodes in boxes and set some of the boxes out of doors through the winter. In the spring the boxes kept indoors still had living nematodes, as shown by gall formations upon plants grown from seeds sown there, while the boxes left out of doors were free from nematodes. It seems probable that the soil in this case dried out in the freezing process sufficiently to kill the nematodes. Ordinarily, however, the frozen soil remains in connection with soil moisture below, and so the drying out and consequent destruction of nematodes does not occur.

'The root-knot nematode does not become active in the soil and begin to penetrate the roots of susceptible plants until the soil begins to be warm. In the tropical and subtropical regions plants are subject to attack the year around, but the farther north one passes the longer is the winter period of comparative immunity from injury by this pest. Thus, in Miami, Fla., there is no dormant period for the nematode. In northern Florida, however, crops planted in the latter part of November or in December show comparatively little injury, nor does the injury begin to be severe until the middle of February or early in March. On the other hand, plants sown in October are infected before the soil becomes cool and are badly injured, the nematodes continuing to develop and spread within the tissues when it is too cool for them to spread outside through the soil. At Monetta, S. C., about half way between Columbia and Augusta, Ga., in the writer's experiments no infection by nematodes could be obtained before the middle of April, while it was the middle of May before they became really active. By the end of September or the middle of October their activity had begun to decline.

Frank ${ }^{2}$ assumed that the chief period of infection was in the spring. He was in error in this statement, for the writer's experiments show that the nematodes are more active in midsummer and that infec- 
tions occur more freely the warmer the weather, except where lack of rain permits the soil to dry out, in which case both plants and nematodes cease to thrive.

\section{CONTROL OF ROOT-KNOT.}

The problem of the control of root-knot is one that varies much according to the place infested, the kind of plants grown, the methods of culture followed, ete. We may distinguish between small, intensively cultivated lots of soil, such as we find in greenhouses, hotbeds, and seed beds, and field culture. Each group may be subdivided in accordance with the answer to the question whether the crops are annual or long lived. For the first great division, owing to the value of the crops raised and the amount of capital invested, methods of combating a disease may be used that would be barred from field crops or other crops on larger areas of land, because the expense would not be justified in view of the comparatively low earning power of the land. Furthermore, the actual monetary loss to the crop due to a given disease may be far greater in the restricted areas of intensive culture than in large fields where each plant is of relatively less value. So, for example, root-knot may affect a field of cowpeas and actually reduce the crop one-half, but unless the field were very large that might not equal the loss sustained by a grower of cucumbers, lettuce, or tomatoes whose whole greenhouse crop has been totally destroyed by the same pest.

GREENHOUSES, SEED BEDS, ETC.

LIVE STEAM.

Probably the most satisfactory method for destroying the rootknot in greenhouses and seed beds is the use of live steam under considerable pressure. This has been advocated by various persons, viz, May, Galloway, Selby, and Rudd, ${ }^{1}$ but it was as a result of careful experiments by Stone and Sinith ${ }^{2}$ that it became generally used. The method recommended by them is a modification of that recommended by Galloway and others. The scheme is essentially as follows: At the bottom of the bench or bed are laid either iron pipes perforated with $\frac{1}{16}$-inch holes every few inches or drain tiles. Live steam is passed into these and escaping from the holes of the iron pipes or between the ends of adjacent tiles heats the soil to such a degree that all animals and most plants (except, of course, bacterial spores) are killed. The pipes must be placed at intervals short enough to permit the spaces between the rows of piping to be thoroughly permeated by the steam. This distance varies with the soil, but 12 
inches is close enough for all general purposes, and even 2 feet is not too far in deep beds if the sterilization is kept up long enough. The bed should be covered with straw, boards, sacking, or something of the kind to permit the upper layer of soil to become heated through. The pipes or tiles in the soil should be arranged lengthwise in the beds, with the steam inlet in a crosspiece of piping running across the bed, from which the longitudinal rows take their origin. A similar crosspiece at the other end may be used, but is not absolutely necessary. There should be no open ends of pipes or tiles; otherwise all the steam will escape out of these and not through the cracks or small holes. Depending upon the pressure of steam used, the time necessary for sterilization will vary from half an hour to even two hours when the pressure is poor.

A method often recommended to determine whether the steam has passed long enough, and one that has considerable merit, is to bury raw potatoes at the surface of the soil underneath the covering of straw, boards, or sacking. When all these potatoes are found to be cooked the steam can safely be turned off. Stone and Smith recommend the use of a special boiler so that steam at fairly high pressure can be used, not under 40 pounds per square inch, preferably more. Even 80 to 100 pounds pressure is not too high if obtainable, as it shortens the time necessary and also prevents the soil from becoming as wet as with lower pressure.

Not only are all nematodes killed by this treatment, but also all insects and other noxious animals, as well as all fungi and their spores. Many bacteria are killed, too, but not all of their spores, the survival of the latter being desirable in view of what we know of the value of soil bacteria.

This method has some disadvantages. Thus, it can not be used for beds occupied by living plants. Furthermore, care must be taken on the one hand not to leave the soil soggy and on the other not to dry it out too much. The latter is, however, a much less serious matter than the former.

FRESH SOIL.

For greenhouses, cold frames, seed beds, etc., where a steam-heating plant is lacking and where it would not pay to incur the expense of installing a boiler for the purpose of using it for soil sterilization, the desired results can be obtained by the use of fresh soil each year. This should be taken from some place in the woods or from a field where the nematode is known not to occur. The old soil should be placed where it can do no harm in the way of spreading the disease. If it can be allowed to become perfectly dry for some weeks before taking it out, the danger from the old soil is greatly reduced. The 
framework of the beds should be thoroughly whitewashed with strong, lot whitewash, freshly made from good quicklime, or it may be painted with formaldehyde or some other disinfectant of this nature. This is to kill all larvæ or eggs that might be in the dirt adhering to the cracks. In selecting new soil it will always be well to examine the roots of susceptible plants growing where the soil is to be obtained in order to determine whether or not root-knot is present. This method has given good satisfaction where carried out in the North. It is applicable, however, only to small greenhouses that do not require much new soil. Large greenhouses can be far better taken care of by sterilizing the soil in the benches.

It often happens that to obtain fresh soil is not desirable in view of the character of the soil in the vicinity. Perlaps it has taken some years to bring up the soil in the beds to the desired lightness, humus content, etc., and to have to take new soil every year would be a hardship. In such cases steaming should be made use of if possible. If it is not feasible, a formaldehyde solution has shown itself of considerable value.

FORMALDEHYDE.

The formaldehyde method consists essentially of treating the soil with a weak solution of commercial formaldehyde (or formalin). It has been found that a solution of 1 part commercial ( 36 to 40 per cent) formaldehyde in 100 parts water is effective against the root-knot nematode in shallow beds when applied at the rate of 1 to $1 \frac{1}{2}$ gallons (or more in the case of very absorbent soils) to every square yard of soil surface. For deep beds the quantity must be increased. Care must be taken that all parts of the soil are reached and thoroughly wetted by the solution. Upon the thoroughness with which it is done depends largely the success of the process. After the formaldehyde solution has soaked in the soil should be thoroughly stirred, so that all parts may be exposed to the disinfectant. Before setting into the soil any plants or sowing any seeds the excess of formaldehyde must be allowed to escape by evaporation or, if necessary, be washed out by flooding the bed. The former is preferable. The writer has not found the germination of seeds interfered with when 10 days are allowed to elapse between the treatment and the sowing of the seeds, especially if the soil be allowed to become rather dry and be stirred in the meanwhile.

This formaldehyde treatment has been used with success at the Ohio Agricultural Experiment Station ${ }^{1}$ in the forcing house and seed beds. It was applied primarily to prevent certain damping-off fungi from destroying the seedlings, but it was found that the nematodes were sometimes destroyed also or greatly reduced in numbers. How- 
ever, as a means of combating nematodes it is not recommended by Prof. Selby. The strength of the solution used there was about 1 to $1 \frac{1}{2}$ parts commercial formaldehyde to 400 of water, which is less than that found to be really effective against this nematode.

The treatment of living plants in the greenhouse to destroy rootknot is fraught with considerable difficulty. Means that will destroy the nematodes are mostly injurious to the plants containing them. Thus, steaming or drying and freezing the soil can not be thought of, as these processes are fatal to the plants. So, too, the use of carbon bisulphid has in a similar way proved not feasible. It is still possible, however, that certain plants less susceptible to this chemical, if perfectly dormant and rather dry, might escape without serious injury when enough of it was used to kill the nematodes present. This must be determined by experiment. Under certain conditions the use of the formaldehyde solution has been found efficacious with some kinds of roses. Many plants are killed outright by the treatment, but roses, at least some sorts, are less susceptible to injury. The first experiments in this line were performed in February, 1902, in the greenhouses of Mr. Loosé, a florist of Alexandria, Va., under the direction of Mr. A. F. Woods, of the Bureau of Plant Industry. The writer cooperated in so far that he examined the roots for nematodes after the experiment. The following extracts from Mr. Loosé's report of the experiment indicate the methods used:

In the early part of February a bed of Bridesmaids, 150 feet long and 3 feet wide, 4 inches soil, was thoroughly saturated, using 50 gallons of the 1 per cent mixture. The plants did not seem to suffer from the application, and one week later we were able to see young healthy roots making their appearance, while the old fibrous roots were entirely decayed. We then treated in the same manner Bride, Kaiserine, Chatanays, Nephetos, Beauty, Liberty, and Meteor with equal success as to freeing the soil of the pest.

Some strong-growing varieties, however, such as Beauties, Chatanays, and Kaiserine, suffered and lost much of their foliage. Even some of the soft growth wilted during the sunny part of the day. My experience in this treatment is that care should be taken to harden the plants by lower temperature and keeping the beds dry, being careful, however, to give the plant a good watering 12 hours before applying the mixture. * * * The cut of roses on February 10, at the time when we applied the remedy, had dwindled down to 250 a day. It remained practically stationary during the four following weeks. We were able, however, to notice that the foliage was regaining its normal color and the plants were starting strong growths. By A pril 1 our cut had increased to 500 daily, mostly prime stock, and by the middle of A pril it had resumed its normal cut of 1,000 .

$\Lambda$ s a matter of experiment we left a few plants untreated at the ends of some of the benches, and to-day, May 10, they are practically worthless, showing effectually that the spring weather had nothing to do with the improvement. The roots of the untreated plants looked like a ball of fern roots used for orchid potting, full of galls and matted, plants making a weakly growth, foliage pale, and flowers insignificant. On the contrary, the plants treated last February have healthy strong roots, making fine growth and the foliage of the very best color.

$$
91294^{\circ}-\text { Bul. } 217-11-4
$$


The mixture was applied with the hose connected to a force pump at the rate of 4 pounds of formaldehyde to 50 gallons of water, the treating of 15,000 plants requiring 200 pounds of formalin, worth about 18 cents a pound, making the treatment quite inexpensive considering the result.

Since this experiment this method has been tried in a number of places and with success where the proper precautions were taken. Doubtless other plants might be treated similarly, but the method should be tried with caution, even for roses, until it is ascertained that the plants will not be killed.

MiscellanEOUS.

Plants for which the formaldehyde treatment can not be used can often be benefited by the following treatment: Remove them from the soil, wash the roots clean, and cut away every diseased root, burning them. Top the plant to correspond with the amount removed from the roots and plant in nematode-free soil. Such severe treatment is too injurious to some plants, and about all that can be done then is to give them plenty of well-aerated soil with an abundance of fertilizer, so as to stimulate root growth to more than counterbalance the roots that are reduced in value by the entry of the nematodes into them.

It is possible that by transplanting diseased plants to stiff clay soil the number of nematodes will be so reduced that a subsequent transplantation to more suitable soil will find them free from the disease.

On purchasing rooted plants, unless they come from a place known to be free from root-knot, it will always be best to put them into a quarantine bench for several months. If at the expiration of this time they show no signs of the trouble, they can safely be removed to their permanent quarters. Of course the soil in the quarantine bed must be renewed whenever it becomes infested with the nematodes.

Moderate quantities of soil can be freed from the pest by putting it at the beginning of winter in a place where it will be exposed to the cold and subject to drying out at the same time. Thus, it can be thrown upon boards in a comparatively thin layer. The boards will keep the nematodes from passing downward into the ground as the soil dries out. At the same time the boards keep the moisture from the soil beneath from passing by capillarity up into the soil from the beds. The continued drying and freezing, especially if the soil be occasionally stirred, is fairly effective in killing off the nematodes.

\section{CONTROI, OF ROOT-KNOT IN THE FIELD ON PERENNIAL CROPS.}

The treatment of perennial crops in the field is of a greatly different nature from that of plants in the greenhouse, cold frame, or seed bed, for a process that could be applied with profit to such valuable soil as that in greenhouses, etc., might, indeed mostly does, prove too 
expensive for ordinary use in large fields where the crop value per given area is far lower. The methods to be applied differ according to whether the land is used for annual or short-lived crops or is possessed by a long-lived crop, such, for example, as fruit trees. In the former case the treatment can be begun after the crop is off, while in the latter it must be of such a nature that the trees present do not receive injury. The latter problem will be discussed first.

In the South the trees most generally affected seriously are the peach, fig, mulberry, and walnut, while in California and Arizona the Old World grapevine is seriously affected in addition. Many other plants are subject to great injury elsewhere, such as coffee in Brazil, Mexico, and the East Indies; papaya (Carica papaya) in Florida and the Tropics; shrubs like tea in Ceylon and India, etc. By consulting the list of plants subject to the disease it will be seen that many are woody plants and that of these a number besides those mentioned are seriously injured by the disease.

\section{CHEMICALS.}

Of the various treatments proposed, the use of chemicals has offered a wide field for investigation and one that is by no means thoroughly explored as yet. The more promising chemicals tested by the writer are mentioned in the following paragraphs:

Carbon bisulphid.-This has been used in Europe for the phylloxera on vine roots where the plants were dormant, without serious injury to the vine. The writer's experiments, however, lead him to look upon it with suspicion. Many plants were very quickly killed by it and others seriously injured. Its use should not be attempted without first testing its effect upon one or two trees. These should preferably be dormant, at least not in an actively growing condition. The root hairs are killed outright, so the plant must not be where it will actively transpire until new root hairs are formed. The usual method of procedure is to make holes in the ground to a depth of several inches or a foot or more, the carbon bisulphid being poured or injected into these holes and the latter covered up with dirt before the liquid volatilizes. The fumes penetrate the soil and destroy nearly all living things. Extreme care must be used in handling this chemical, as its fumes are poisonous and exceedingly inflammable, being explosive when enough air is mixed with them.

Carbon bisulphid will doubtless be of value in an orchard or grove where it is desired to replace certain trees or fill vacant places with new plants. By its use the spots where the old trees stood or where vacant places are to be filled can be thoroughly disinfected. After a weck or two the trees can be set out and, the soil being free from nematodes, can make quite a start before the nematodes from the 
soil outside of the disinfected patch can get to their roots. In deep sandy soil the writer found not all the nematodes destroyed by the use of 2 ounces of carbon bisulphid per square yard, but when 4 ounces were used they were exterminated. The size of the area to be treated depends upon the size and rapidity of growth of the trees to be planted, the faster they grow the smaller being the area to be treated. For the best results the ehemical must be placed at a depth of several inches below the surface, the opening being firmly closed so that the vapors will have to diffuse throughout the soil. In France special forms of apparatus have been devised for this purpose in combating phylloxera. They consist of a reservoir for the liquid and a hollow rod which can be inserted to any desired depth, a measured quantity of the liquid then being foreed out into the soil. In the writer's experiments, however, use was not made of these rather expensive contrivances, but of a simple dibble consisting of a pointed piece of broomstick. Holes were made to the depth of a foot to the number of eight or nine to the square yard. The desired amount of carbon bisulphid was poured into them, each being closed at once by the foot and the earth firmly pressed down to prevent the escape of the vapors into the air. About a teaspoonful to each hole is sufficient, or about 4 ounces to the square yard.

Potassium sulphocarbonate.-Potassium sulphocarbonate in the form of a solution of 1 part, by weight, to 5 parts of water to be applied in little trenches dug around the diseased trees is recommended by Gándara. ${ }^{1}$ According to him, 4,000 liters of the solution suffice for a hectare-i. e., about 425 gallons per acre. His experiments were with nematode-affected coffee. This treatment he reports as beingsuccessful, but too expensive for general use. The writer's results, however, were not so successful. Papaya plants (Carica papaya), about 18 to 20 months old and with roots badly affected with root-knot, were used. The chemical, diluted as directed by Gándara, was applied to some trees in little ditches and to some in numerous holes about a foot deep. After it had all soaked in, the soil was watered thoroughly, as it was very dry, so that the chemical might the better soak evenly through the soil. In a day or two some of the old leares dropped, showing that the roots had suffered some injury; but at the expiration of a few weeks the roots were found to be as badly knotted as ever, proving that for the papaya, at least, this process is ineffective. The high cost of the chemical, moreover, would make its use utterly impracticable.

Formaldehyde.-In view of the comparative success obtained with formaldeliyde solution on roses it was tested on papaya trees out of doors. A ridge of earth was made around each tree at a distance of 
about 5 feet, so as to retain the solution. One part of commercial formaldehyde (about 40 per cent strength) was mixed with 100 parts of water. About 25 gallons were applied to each tree-i. e., about 3 gallons to the square yard. In some cases water was applied afterwards to cause the solution to penetrate deeper; in other cases no water was added. A few of the older leaves turned yellow and (lropped off a day or two after the treatment, but no further injury was noticeable. In two weeks the nematode root galls, containing living nematodes, were found to be almost as numerous as ever, although a good many of the galls on the roots nearest the surface were found to contain dead nematodes. These and other experiments lead the writer to believe that where the soil is rather deep and the liquids applied can drain through instead of remaining in the immediate vicinity of the roots this formaldehyde treatment is not likely to prove very effective.

Calcium carbid.-The use of calcium carbid was also recommended by Gándara. ${ }^{1}$ His instructions were to mix 4 parts of it with 1,000 parts of water. After letting it stand half an hour this milky solution is to be injected into the soil in five holes per square meter, 10 grams to a hole. Through lack of other trees suitable to test it on, papaya trees were also used in testing this method. A modification was also made in that about an ounce of the calcium carbid, without previous treatment with water, was placed in the bottom of 8-inch holes, which were promptly plugged with earth, about eight or ten holes being made to the square yard. Afterwards the soil was thoroughly watered. In this case a strong odor of acetylene was noticeable for two days. No damage was done to the trees and the nematodes in the galls were not killed by either treatment.

Other chemicals. - Various other chemicals recommended have the disadvantage that they are poisonous to living plants or too expensive. It is still possible, however, that some easily volatilizing liquid may be found whose vapors while fatal to the nematodes will not seriously injure the plants harboring them. Of those already mentioned carbon bisulphid has many desirable qualities; but its poisonous effect on vegetation is against it. It is possible that by applying it only during the dormant season of the plant and carefully regulating the quantity applied it may prove as effective as it is claimed by some investigators to be against phylloxera in the vine. The writer's experiments were mainly carried on at Miami, Fla., where there is no dormant season; hence this point could not be well determined. It is also conceivable that after a period of dry weather the chemical might be less harmful, as the trees would then be in a less actively 
growing condition and perhaps, therefore, less injured when the root hairs were killed by the chemical. Further experiments on this line should be carried out.

FERTILIZERS.

It is the result of general observation that if trees affected by rootknot can be foreed into rapid growth, especially in the early part of the season, so that the roots penetrate deeply into the ground and form a widely branching system, they will thenceforward usually develop normally and cease to show much injury from the nematode. This is particularly the case with the peach. Many growers now on setting out an orehard where the pest is present fertilize the trees very highly, so that they may start right into growth and keep ahead of the nematode injury. As shown on page 41, the nematodes are mostly confined to the upper 12 to 16 inches of soil, so that if the roots can be foreed to grow rapidly and deeply enough they will eseape much injury. To accomplish this, it is necessary that the soil be prepared to a good depth before setting out the trees and that an abundance of nitrogenous fertilizers be given. The various potassium salts, too, are apparently very beneficial in the Southeastern States, so much so that some people believe that they destroy the root-knot nematode. Perhaps in the naturally rather potash-poor soils of many of the Southern States the addition of potassium is simply another factor in bringing the plant to its normal resistant power. At any rate, in the writer's experiments plants given an excess of potash suffered less from root-knot than those not so fertilized. It has been found in Germany that the sugar-beet nematode removes the mineral salts from the roots about equally. If, however, the soil is not much overstocked with potash it would be exhausted in the plant sooner than the others, for, being less abundant in the soil, it would be taken up less rapidly by the roots. The same would be true of any other of the necessary minerals. This may explain the effect of potash in combating this disease.

FLOODING.

In view of the fact that root-knot injury never seems to be severe in soils that are flooded for a part of each year it seemed reasonable to suppose that flooding might have a beneficial effect when applied to affected trees. Unfortunately, however, through a misunderstanding of instructions the experiments arranged to be carried out on this line failed to be performed. It is certain, however, that great eare must be taken, for many trees are killed by having their roots submerged even a few days.

217 
CONTROL OF ROOT-KNOT IN THE FIELD WHEN NO CROP IS PRESENT.

Land known to contain the root-knot nematode and not occupied by a permanent crop like an orchard, grove, ete., may be freed from the pest far more readily than land so occupied. The methods are the same, whether the land is to be planted subsequently to annual crops or to trees. The only difference is that land destined for perennial erops must be more thoroughly cleared of the root-knot nematode than that destined for simply one-year crops.

\section{CHEMICALS.}

Carbon bisulphid.-Carbon bisulphid is undoubtedly the most efficient chemical for the destruction of the nematode in fields. Experiments were made by the writer at Monetta, S. C., in 1906 and repeated in 1907, which showed that when used as previously described at the rate of 4 ounces per square yard of surface the nematodes were practically exterminated, being found only at the edges of the plats, where they could have come in from the surrounding untreated land. Two ounces per square yard did not prove so effective, although the nematodes were largely destroyed by even this application. In view, however, of the quantity required and of the high price of this chemical it is very evidently out of the question to apply it on a large scale. Even in bulk the crude carbon bisulphid costs 10 to 15 cents a pound. At 4 ounces a square yard the cost for an acre, not including cost of the labor required, would be from $\$ 120$ to $\$ 180$. Nearly all the chemicals that have been suggested have the same fault. Yet for small patches when it is desired, perhaps, to destroy the nematode where a tree is to be set out, or in a small spot where the pest has appeared but has not spread badly, it would probably be found very effective.

Formaldehyde.-Formaldehyde was tested at Monetta, S. C., in both 1906 and 1907, and at Miami, Fla., as well, in 1906. It was applied as a solution of 1 part commercial formaldehyde (36 to 40 per cent) in 100 or 200 parts of water. The solution was either sprinkled directly on the surface or poured into deep furrows, which were leveled off after the solution had soaked in. From 1 to 2 gallons per square yard of surface were used. As a whole, the treatment did not recommend itself. In no case were the nematodes entirely destroyed, although they were considerably reduced in numbers. The plants grown on these plats after the treatment showed the presence of root-knot galls on their deeper roots, although most of the upper layer of soil seemed to be free from the pest. This would indicate that a larger quantity would perhaps penetrate deeply enough to kill all the nematodes in the soil. With formaldehyde at 20 cents a pound, wholesale, the cost of treating an acre with the stronger solution, 
2 gallons per square yard, would be about $\$ 150$ exclusive of labor, which would include the hauling of 5,000 to 10,000 gallons of water.

Calcium carbid.-At Monetta, S. C., experiments were made with calcium carbid. It was strewn in furrows which were then covered over so that the resulting acetylene gas should penetrate throughout the soil, or it was applied as a solution in water. The amount of rootknot was reduced, but in all cases where the reduction was great the injury to the crops, especially to tomatoes, was also great. Better results were obtained from the dry application in 2-inch furrows than from the solution. Planting was not undertaken for a week or two, but still the results were such that in spite of replanting a second and even a third time the test crops - okra, beans, tomatoes, and cowpeaswere badly killed out. The odor of acetylene was perceptible for several days. The fairly effective amounts were 1,500 pounds per acre, dry, in shallow furrows or a solution of 5 pounds per 100 gallons of water applied in deep furrows, 1 to 2 gallons per square yard. In view of the high cost of the treatment (at 10 cents a pound this would be $\$ 150$ per acre exclusive of labor for the dry application and $\$ 25$ to $\$ 50$ for the solution) this method can not be recommended. The injury to vegetation is also against it.

Potassium sulphocarbonate.-This salt is obtained commercially as a concentrated dark-brown solution, smelling strongly of sulphureted hydrogen. Gándara ${ }^{1}$ states that it has been tried against phylloxera in France and recommends it for root-knot, at a rate of 1 part of potassium sulphocarbonate to 5 parts of water. Accordingly, the following experiments were outlined. Plats of land were laid off as follows: (1) Check, no treatment; (2) 10 parts of the chemical to 90 parts of water, 2 quarts per square yard in holes which were quickly filled; (3) 1 part to 99 of water poured on the surface at a rate of 2 gallons per square yard, that being the quantity necessary to wet the surface thoroughly; (4) a similar quantity of a solution of 1 part to 199 of water; (5) check. After a few days beans, tomatoes, okra, and cowpeas (New Era) were planted. In all cases where the chemical was used, both weak and strong, the tomatoes, okra, and beans were to a large extent killed, but the cowpeas were not hurt. Root-knot was present, however, even where the solution was the strongest. As a fungicide, too, this chemical had little value, for Rhizoctonia was very abundant at the crowns of all the plants.

For field use, then, this chemical is not to be recommended as a means of combating the root-knot nematode.

Ammonium sulphate.-Van Breda de Haan² recommended against the nematode on tobacco in the Dutch East Indies the use of ammonium sulphate followed by quicklime. The latter sets free the 
ammonia, which that author supposed might have value in destroying the pest. The writer's experiments at Monetta, S. C., were as follows: Plats of nematode-infested land 10 feet by 70 feet and 10 by 140 feet were laid off, separated from one another by ditches 2 feet wide. The chemicals were scattered on the surface and worked in with a cultivator or hoe. The rate per acre of the applications is here given, not the actual quantity put on the particular plats. (1) Water-slaked lime (quicklime put in a hole in the damp earth and left several days until slaked to a powder) 2 tons per acre, ammonium sulphate 1 ton per acre; (2) quicklime 2 tons, ammonium sulphate 1 ton; (3) slaked lime 2 tons; (4) quicklime 2 tons; (5) check. Summer squashes were planted on one half of each plat and New Era cowpeas on the other half, both these crops being very susceptible to nematodes.

Plats 3 and 4, respectively, slaked lime and quicklime, showed a very great abundance of root-knot, even more than plat 5 , the check. The plants were pale in color and weak. Evidently lime in the quantities used is not effective against root-knot. In plats 1 and 2, ammonium sulphate plus slaked lime and quicklime, respectively, the squash roots were fairly badly knotted, especially in plat 1 , but not nearly so badly as in plats 3 and 4 or in the check plat (5). The cowpeas were very dark green in color and very vigorous, and only moderately affected with root-knot, far less than plats 3 or 4 , perhaps about like the check. The two plats with ammonium sulphate ripened their seed earlier than any other of the experimental plats. The next year these plats were again planted, this time to cowpeas, okra, tomatoes, and beans. The chemicals were not added, but observations were made to determine whether any beneficial effect might show the second year. The ammonium-sulphate plats were distinctly better than the check or those with lime alone, and were only moderately affected with root-knot, although by no means free from it.

Experiments similar to these but on a very much smaller scale were made in Miami, Fla. Quicklime, even at the rate of 5 tons to the acre, did not suffice to prevent nematode injury, while root-knot was quite abundant in a plat treated with quicklime at the rate of 2 tons per acre with 2 tons per acre of ammonium sulphate dissolved and poured over the surface.

We must then conclude that these chemicals are not of special value for the combating of nematodes.

Abbey ${ }^{1}$ recommends using silicofluorid of ammonium at the rate of 1 ounce to a square yard. It must not be applied to soil containing living plants, as it will kill them. It soon decomposes and then is 
harmless. Abbey also recommends 3 ounces of Little's soluble phenyl in 3 gallons of water applied around affected roots. Dyke and Iggulden ${ }^{2}$ also tried the latter, but Dyke found it a failure, claiming, however, that kainit was effective.

FERTILIZERS.

Closely related to the use of chemicals may be considered the effect of various fertilizers on the development of root-knot. At Monetta, S. C., the following fertilizers were tested in 1906, mostly in onetwentieth acre plats separated by ditches (or rather very deep furrows) 2 feet wide, the numbers in parentheses referring to the field numbers of the plats: (12) Kainit, 1,000 pounds per acre; (13) ammonium sulphate, 667 pounds per acre; (14) kainit, 500 pounds per acre; (15) high-grade potassium sulphate, 1,000 pounds per acre; (16) check; (17) high-grade potassium sulphate, 500 pounds per acre; (18) 17 per cent acid phosphate, 1,000 pounds per acre; (19) 17 per cent acid phosphate, 1 ton per acre; (20) check. In 1907 the following tests were made: (1) Kainit, 1,000 pounds per acre: (2) kainit, 1,500 pounds per acre; (3) high-grade potassium sulphate, 667 pounds per acre; (4) high-grade potassium sulphate, 1,333 pounds per acre; (5) ammonium sulphate, 1,000 pounds per acre; (6) muriate of potash, 1,000 pounds per acre; (7) potassium magnesium carbonate, 667 pounds per acre; (8) potassium magnesium carbonate, 1,333 pounds per acre. The checks received no numbers in 1907 . The plats of that year and the checks were planted to tomatoes, okra, beans, and New Era cowpeas, all of which are very susceptible to root-knot. The last year's plats (1906 experiments) were also replanted in 1907 with these four plants. In 1906 the fertilizer plats were planted with New Era cowpeas and summer squashes. To all of the fields was applied cach year, at the rate of 500 pounds per acre, a special brand of commercial fertilizer in common use in that vicinity, the soil being so poor that without some complete fertilizer nothing would grow well. The experiments were intended to show the effect, if any, of an excess of some particular fertilizer over the normal quantity applied.

The 1906 plats showed plainly the beneficial effects of potash fertilizers on the sandy soil of the experimental field. All the plats treated with kainit and potassium sulphate were darker green and the plants were far more vigorous than on the other plats. In fact, plats 12 and 15, respectively, kainit and potassium sulphate, both 1,000 pounds to the acre, were, so far as the cowpeas were concerned, hard to excel anywhere. The squashes did not show much difference in any of the plats. They were badly infested with the squash bug, 
which killed the plants out in some of the plats. The cowpeas in plat 12 showed no nematodes and but few were present in the squashes. Plat 14 had a fair amount of root-knot in the cowpeas and from few to many on the difierent squash plants. The rest of the plats did not differ materially from the check plats which were fairly badly affected, in spots very badly.

The plants grown on these same plats in 1907 without the addition of the fertilizers again were badly affected except in plat 12, and somewhat in plat 15, which remained fairly free, showing a resiclual effect.

In the 1907 fertilizer experiments the following results were obtained. The kainit applications were injurious to the germination of the seerls, both the 1,000 as well as the 1,500 pound application, but naturally the latter more markedly. The amount of rootknot, however, in these plats was slight. Potassium sulphate at 667 pounds per acre was not injurious, but at twice that amount it so injured the germination of the cowpeas and beans that they required replanting. Root-knot was fairly abundant and, strangely, more so in the more highly fertilized plat. In both plats the growth of the plants was very vigorous. The sulphate of ammonia at the rate used exerted a very harmful effect on germination, requiring several replantings. The plants that did grow, however, were very vigorous, dark green, and rather free from nematodes. The muriate of potash injured the germination of the beans and cowpeas, while the nematodes were fairly abundant. The potassium magnesium carbonate gave the best and most vigorous plants of all, without injury to germination. Root-knot was present in most of the plants, but not abundant.

Juching from these experiments, it is clear that fertilizers alone can not be depended upon to exterminate root-knot. On the other hand it is also plain that some fertilizers exert a beneficial effect upon the plant and enable it to make a good crop in spite of nematodes. Perhaps they may also increase the resisting power of the plant against the entrance of the nematodes into the roots. The potash fertilizers seem to be most favorable for this purpose, so far as the experiments at Monetta and observations elsewhere go. However, it will not be safe to conclude that they will be equally beneficial everywhere. In the sandy, rather potash-free soils of South Carolina and Florida the application of potash in amounts not too large seems to be followed by favorable results.

According to Stift, ${ }^{1}$ Hollung, in Germany, has shown that fertilizing highly with potash alone is not of much benefit to beets attacked by the sugar-beet nematode. Wimmer has shown that the nema- 
todes remove the different minerals almost equally, so that only where one element is rather deficient will the addition of that alone be of benefit. The sugar-beet nematode removes large quantities of mineral food from the roots, so that unless these minerals are present in the soil in considerable excess over that naturally needed by the crop the plants will suffer from lack of that mineral which is not sufficiently superabundant. 'Thus, an amount of potash sufficient for a healthy crop may be insufficient if the sugar-beet nematode is present, and the symptoms of potash hunger can be averted only by applying an excess of potash. Probably this is also true of the rootknot nematode. The sandy soils of South Carolina are rather potash poor, so that a diseased plant will suffer from potash hunger, while the other elements may be in sufficient abundance. At any rate, the addition of potash in excess proved helpful. 'The nitrogencontaining fertilizers when not in too great excess also benefited the plants somewhat, but not so markedly as the potash. This is to be expected, as nitrogen is not any too abundant in those soils. The phosphatic fertilizers, however, showed no benefit at all.

Caution must be taken not to apply too much potash. In 1907, in fact, kainit at 1,000 pounds per acre was harmful in that many of the young seedlings were killed, necessitating replanting several times in order to get a fair stand. This quantity was not harmful in 1906 on another plat, showing that the danger limit is probably not far below that amount. Muriate of potash at the same rate was very harmful in 1907, as was also the same amount of ammonium sulphate. Potassium sulphate, 667 pounds to the acre, and potassium magnesium carbonate, 667 and 1,333 pounds to the acre, were absolutely harmless, while the latter amount of potassium sulphate was only slightly harmful.

In spite of the high fertilization a field continually planted to nematode-susceptible crops will, if the nematode is present, eventually become so infested with that parasite that it will be impossible to make paying crops. Howerer, it can not be denied that for special occasions it is of value to reduce part of the evil effects of the nematode infestation by high fertilization.

FLOODING.

The objections to flooding the soil that would apply in the case of land occupied by permanent crops do not hold good in fields devoted to annual or short-period crops. In the former case the soil can not be kept submerged longer than a few days or the roots are killed. In the latter case, however, the fields can be flooded for as long a period as desired before the crops are planted. There is no doubt that under such conditions flooding has value. This has already 
been mentioned, reference being made to the conditions in the Everglade islands, where the never submerged tops of the islands are full of root-knot and the annually submerged sides are free from it. The writer has records of fields in Georgia badly infested with the rootknot nematode that were free from the trouble after a spring freshet that kept the ground submerged several days.

Apparently flooding, unless possibly of long duration, will not kill the nematodes inclosed within the root galls, so that if such knotted roots of perennial plants are present the flooding must be continued much longer. In Yuma, Ariz., under the writer's directions a field was flooded. It had once been a vineyard of Old World grapes, but these had become unprofitable owing to the ravages of the root-knot, and the vines had been cut down or pulled up. Many of the roots, however, were left in the ground. The next year the field was planted to melons. When the writer saw the field in May, 1907, the young cueumber and melon plants were dying from root-knot and the pest was found in the old living grape roots. The field was flooded the following winter, but root-knot was again prevalent the following spring, although apparently not so abundant. It seems likely that the vine roots may have harbored and saved from destruction many nematodes, or perhaps the flooding was not continued long enough. That under some circumstances even three weeks is insufficient appears to be the conclusion to be drawn from an experiment performed at the writer's suggestion by a fruit grower and nurseryman in California. He kept submerged for three weeks his field of sandy alluvial soil which was badly infested by nematodes. Afterwards grape cuttings and peach seedlings were set out in it. The grapes (a resistant sort, Rupestris St. George) showed no root-knot, but the peaches became knotted. This period seems excessive in view of laboratory results, and is not entirely free from doubt as to other possible means of infection, yet, until disproved, three weeks should be regarded as not enough time to exterminate the nematode by flooding.

It is of interest that flooding the soil is claimed by Stift ${ }^{1}$ to be of no value against the closely related sugar-beet nematode.

Flooding, then, can not be recommended as a certain means of exterminating root-knot mder all circumstances. Probably the soil should be flooded at least 25 days; in the laboratory the nematode larvæ usually succumbed much sooner when isolated and placed in water. Furthermore, no roots of perennial susceptible plants must be present. When water is expensive or means of flooding are not at hand, or when the soil is too porous, it will be out of the question to try this method. The subject is one, however, that needs further investigation. It will be of interest to call attention to the phenom- 
enon often observed that a sloping field may have nematodes at its upper or middle portion and be free from them at the lower end where the soil is water-soaked part of the year.

DRYING.

Laboratory experiments by the writer seem to show that the rootknot nematode can not withstand the drying out of the soil. Thus, two pots of badly infested earth, containing badly knotted plants, were allowed to remain without watering from June 4 to September 22,1908 . The soil became very dry and dusty. It was then watered and seeds of susceptible plants were sown. These remained entirely free from root-knot. It is certain that the adults are killed by drying ont, they being, indeed, very susceptible to injury of that kind. The foregoing experiments led the writer to the conclusion that thorough drying was fatal to larva and eggs as well. This was strengthened by the observation that in his cross-inoculation work where carefully washed root-knot roots of various plants were planted in sterilized pots of soil and seeds of the desired plants sown in the pots, infection was obtained wherever the roots used were fresh, while whenever they were somewhat wilted, not even dry, no infection was obtainable. Frank ${ }^{1}$ and Stone ${ }^{2}$ were also of the opinion that drying out was fatal to these nematodes.

On the other hand, there are several recorded observations which would seem to indicate that the opposite is true, at least sometimes. Thus, Göldi ${ }^{3}$ dried the roots of coffee affected with root-knot, both in the sun and in the shade. After two months he wet them up and soon found, with the aid of the microscope, numerous nematode larvæ, which he considered to be those of the root-knot nematode. A second case was as follows: Prof. P. H. Rolfs, of the Florida Agricultural Experiment Station, ${ }^{4}$ kept some sandy soil in the laboratory for 10 months. It became dry long before the expiration of that period. The soil was watered and tomato seeds were sown. The radicles of the seedlings became swollen and œedematous in a manner resembling the work of the root-knot nematode. No nematodes were found within the roots, but clinging to the outside were found nematodes which he identified as Heterodera radicicola.

Göldi's conclusions may have been erroneous, for there are many nematodes, almost indistinguishable from Ileterodera radicicola in the larval state, that endure drying out for long periods. If they were examined only with the microscope and not tested in connection with living plants on which they could be grown to maturity, it would be almost impossible to tell whether those seen by Göldi were the one or the other. Prof. Rolfs, on the other hand, is not likely to have made 
a mistake of this nature, performing the experiment as he did. Still it is not certain that he had Heterodera radicicola unless he actually had the mature nematodes, but on this point he says nothing. There are some other nematodes besides this species that cause root galls, and it is barely possible that it may have been one of these, not the root-knot nematode that Prof. Rolfs had, since this latter species is rarely even partially extermal in the tomato. Yet with the confirmation of these reports by Dr. Cobb's observations, it can hardly be doubted that under some circumstances some of the root-knot nematodes may survive drying out of the soil.

Whether the drying out of the soil kills all the root-knot larvæ or not, there is no doubt that their activity ceases and there is no injury by them in fairly dry soils. In a letter to the writer, C. P. Lounsbury, entomologist of the Department of Agriculture of the Cape of Good Hope, states that the nematode occurs only in loose soils well supplied with moisture. Badly knotted grapevines set out in rather dry soil not only recovered, at least in part, but the nematodes did not spread to surrounding susceptible plants. Lavergne ${ }^{1}$ in Chile, Gándara ${ }^{2}$ in Mexico, and Huergo ${ }^{3}$ in Argentina also point out that dry soils are unfavorable to the development of root-knot. The writer has repeatedly sought for these nematodes in susceptible plants in dry soil outside of but in close proximity to badly infested irrigated fields in the semiarid parts of the country, but without success.

In view of the foregoing facts, it is probable that deep plowing, so as to loosen up the soil quite deeply without harrowing to pulverize it, would permit it to dry out sufficiently in a dry season to reduce greatly the injury from the pest. Of course, this is possible only where the climate is dry and the rainfall slight. In irrigated districts it could probably be carried on, such fields not being irrigated for some months after plowing. Of course this will not have much effect if underground seepage or rains keep the soil moist. Unfortunately the writer was unable to test the efficacy of this proposed method by direct experiment. It is a method that should be tested at the earliest opportunity in those regions where it can be carried out.

TRAP CROPS.

After Kühn, the great German agriculturist, had demonstrated ${ }^{4}$ that the so-called Rübenmüligkeit (beet tiredness) of sugar-beet fields was due to a nematode, Heterodera schachtii, he devised ${ }^{5}$ a method of reducing the injury based upon the principle of trapping the nematodes in some susceptible plant and destroying the latter before the larvæ which had entered the roots had reached maturity. For his trap crop he used a sort of summer rape. This was sown closely and

1 Lavergne, 1901.

2 Gándara, 1906. - Kühn, 1881, 1882, 1886-1, 1886-2, 1891.
4 Kühn and Liebscher, 1880. 
when the plants had grown long enough so that the first nematodes that entered the roots were not yet mature but were in the nonmotile stage they were plowed up and either removed and destroyed or turned under with the tops down and roots up. The plants treated in the latter manner died quickly and the nematodes in the exposed roots died within a few hours. By repeating this process several times (three to five) in a season the number of nematodes was found to be so reduced that good crops could be grown again for several years. In using this method extreme care must be taken to plow under or remove the plants at the right time, for if left too long the nematodes will reach maturity in the roots and lay eggs, thus increasing instead of diminishing the number of nematodes in the soil.

Frank ${ }^{1}$ and others have also recommended this method for combating the root-knot nematodes. The writer has found no record of any such experiment having been tried. He made experiments on this line two different years at Monetta, S. C., but with no success. A badly infested field was separated from adjacent plats by a shallow ditch, 2 feet wide. The plat was sown very thickly to Whippoorwill cowpeas, a variety susceptible to root-knot. Roots from numerous plants were examined microscopically at short intervals to determine the stage at which the nematodes first entering the roots had become motionless and were approaching sexual maturity. At that stage the plants were destroyed, on one plat by plowing them under, on another by loosening the roots and removing and destroying the plants, roots and all. The time necessary to reach that stage was found to be from 19 to 21 days after the sowing of the seed. As soon as the trap crop was removed or turned under, the soil was made ready and resown with cowpeas, the process being repeated. This was done until four or five crops of cowpeas had been removed in this manner. The next year through these plats and the check plat were planted rows of tomatoes, beans, okra, and New Era cowpeas. Some of these plants remained free, while some were slightly affected and some very badly affected by root-knot, no difference being noticeable between the trap-crop plats and the check plats. This was true both in the experiments of 1906-7 and of 1907-8, which were conducted on another field.

The cause of the failure of this method can not be that a sufficiently susceptible host plant was not chosen, for the variety of cowpea used is very susceptible. Furthermore, cowpeas had been grown frequently on that land, so that the nematodes were, so to say, accustomed to that crop. The period of growth allowed was carefully checked by microscopical examinations so as to avoid any chance of letting the development of the nematodes progress too far, for if that

1 Frank, 1885. 
were permitted and egg laying were started the number of nematodes would be increased instead of diminished. Probably such large mumbers were present that only a part entered the trap plants and were destroyed, enough remaining in the soil to infest badly the next year's crop. It is possible that some other crop would have done better, but it could not have been clover, as Frank suggested, for that dic not do well where the experiments were being carried on. The requisites of a good trap plant are fairly cheap seed, great susceptibility to nematode attacks, a wide-spreading root system, and rapid growth. All these are possessed by the cowpea to a greater or less extent.

STEAM

It has been seriously proposed to use steam to destroy nematodes in the field in view of the success with its use in the greenhouse, cold frame, and seed bed. The writer has made no experiments along this line, owing to the expense of the undertaking. It is seriously to be doubted whether a large field, producing a crop selling at $\$ 25$ to $\$ 50$ or even $\$ 100$ net per acre, could be profitably piped for steam sterilization. Small fields isolated from danger of reinfection by deep ditches, water, stiff soil, or other obstacles and devoted to the intensive culture of some very remunerative crop might be so treated with profit. For a large field a very large boiler and many hundred feet of perforated pipe would be necessary to steam the soil by the greenhouse method.

Several schemes for sterilizing the soil in a field by means of movable apparatus have been devised, some of which have proved effective under certain conditions. Thus, for combating the Thielavia root-rot of tobacco, Gilbert ${ }^{1}$ recommends the inverted-pan method of steam sterilization. This was devised by Mr. A. D. Shamel, of the Bureau of Plant Industry, for sterilizing nematode-infested soils in Florida. 'The following description is taken from Gilbert's account:

The apparatus consists of a galvanized-iron pan, 6 by 10 feet and 6 inches deep, which is inverted over the soil to be sterilized and the steam admitted under pressure. The pan is supplied with steam hose connections, has sharp edges, which are forced into the soil on all sides to prevent the escape of steam, and is fitted with handles for moving it from place to place, the weight of the entire pan being not over 400 pounds. The soil is prepared as in the greenhouse method, a few potatoes being buried at a depth of a foot to gauge the degree of heat attained. A soil thermometer may also be used if desired. The steam should be kept at as high a degree of pressure as possible, so to 100 pounds being best, and the treatment should continue for one to two hours, lepending on the pressure maintained. In experiments conducted in the spring oi 1907 , one hour's steaming at $80^{\circ} \mathrm{C}$. under 100 pounds pressure gave best results in killing both the fungus and the weed seeds. When one section of the bed is treated, the pan is lifted and carried to an unsterilized portion and the operation repeated until the entire bed is steamed. 
The great objection to this method, and one that makes it impracticable except for use on small spots, is the smallness of the area that can be treated at one time. Even with a pan of twice the area of that described, and allowing only one hour's sterilization each time, it would require more than 15 days, working day and night, to sterilize the soil on one acre of land. Furthermore, for deep soils, where, as already explained, the nematode sometimes is present at a depth of more than a yard, it is extremely doubtful whether the steam would penetrate deeply enough to destroy all the nematodes. This last objection applies to all methods of sterilization where an attempt is made to kill the nematode by heat or poisons.

FALLOW.

It is self-evident that if a field be kept free from all vegetation for a long enough period all the plant-parasitic nematodes within the soil will die from starvation. This is the principle involved in the use of the bare fallow. The field is plowed and kept free from weeds and other plants by frequent cultivation. In those localities where the winter is cold enough to prevent the further development of the nematodes during that period, it does no harm if grass or weeds grow up after the weather has become decidedly cool. This date might safely be put at November 1 for North Carolina, South Carolina, northern Georgia, Alabama, Mississippi, northern Louisiana, and northern Texas. In central and southern Florida and probably the southern portion of Texas and Louisiana, however, the nematode is active the year around, so that it would be necessary to keep the ground bare the whole time until the nematodes had died. In the early spring, where vegetation was allowed to grow in the winter, the cultivating to keep down the weeds must be taken up again before the soil begins to warm up. The length of time necessary to remain in fallow is not certainly known. Mr. A. D. Jackson, of Denison, Tex., found that 15 months in fallow was not sufficient to rid a field of root-knot nematodes entirely, although the number was greatly diminisherl. On the other hand, two whole years seem to be amply sufficient.

This method has some objections which make it impossible to use in some localities. The land is idle and not only not productive, but requires the expenditure of time and labor to keep the vegetation down. Furthermore, the light soils where the nematodes abound are easily leached out when there is not a covering of vegetation. Then, such soils are subject to bad washing during heavy rains when they have no plant roots to bind them in place. A further objection is the destruction of humus in the soil exposed directly to the action of the fierce summer sun. The use of this method therefore can not be unirersal, although it is successful where it can be put into effect. 
NONSUSCEPTIBLE CROPS.

The most promising method, and the one that has given the best results wherever carefully tried, is that of growing crops that are not subject to root-knot until the nematodes causing the disease are starved out. To carry out this method successfully several things are requisite: (1) The crops planted must be free from nematode attack, so that the larve in the soil may not be able to find any nourishment to sustain their life and enable them to undergo their development. (2) The crop grown should at least pay the expense of working the land, as well as the rent, taxes, ete. (3) At the same time, if possible, the crops should enrich the land, or at least not impoverish it.

The plants must make such a vigorous, dense growth as to choke out all weeds or other plants that might harbor nematodes and permit them to develop and produce their numerous eggs.

On referring to the list of susceptible plants it will be seen that with few exceptions none of the ordinary farm crops fulfill the first requirement. However, the following plants appear to be free from nematode attack, at least under most conditions: Cowpea (the Iron variety), all species tested of Stizolobium (the velvet bean and close relatives), Florida beggarweed (Meibomia mollis), peanut (Arachis hypogaea), rye (Secale cereale), most varieties of winter oats (Avena sativa), crabgrass (Syntherisma sanguinatis), and possibly a few others. Webber and Orton ${ }^{1}$ first called attention to the nematode-resistant quality of the Iron cowpea and recommended its use in combating root-knot. The velvet bean and beggarweed have been recommended by Rolfs, ${ }^{2}$ of the Florida Agricultural Experiment Station, who has also pointed out the value of crab-grass in a plan of rotation for reclucing the number of nematodes. 'Thus, he found the nematodes far less abundant the next year after an infested field was allowed to grow up to crabgrass for one year.

The following rotations were planned by the writer for his work at Monetta, S. C., there being four plats measuring, respectively, 0.152, $0.217,0.217$, and 0.166 acre:

TABLE III.-Rotation of crops planned for four experimental plats at Monetta, S. C.

\begin{tabular}{|c|c|c|c|c|}
\hline Season. & Plat 1. & Plat 2. & Plat 3. & Plat 4. \\
\hline $\begin{array}{l}\text { Winter... } \\
\text { Suminer. }\end{array}$ & $\begin{array}{l}\text { Abruzzes rye. } \\
\text { Beggarweed. }\end{array}$ & $\begin{array}{l}\text { Abruzzes rye.. } \\
\text { Velvet bean.. }\end{array}$ & $\begin{array}{l}\text { Virginia winter oats... } \\
\text { Velvet bean.......... }\end{array}$ & $\begin{array}{l}\text { Yirginia winter oats. } \\
\text { Beggarweed. }\end{array}$ \\
\hline
\end{tabular}

This experiment was planned for three years. It was begun in the fall of 1905 . It was planned to keep careful records of all yields, etc., but in some cases the records are lacking. Unfortunately, the soil 
proved so rery poor for the oats that for it was substituted Abruzzes rye in succeeding years. Once each year the land was fertilized with the special commercial fertilizer previously mentioned at the rate of 500 pounds per acre.

The grain was harvested when mature, thrashed, and measured. As soon as the land could be put into proper condition the beggarweed and relvet bean seed were sown. In October a measured part of each field was carefully mowed and the vines cured to hay and weighed, thus permitting an approximate estimate of the actual yield per acre. The grain was sown as soon as the hay crop was cut and the land prepared. Unfortunately it was impossible, in addition to the substitution of rye for oats, to carry out the rotation just as planmed, for in 1907 the beggarweed seed obtained germinated so poorly that those plats were resown to velvet beans, as it was then impossible to get good beggarweed seed.

In the summer of 1908 across the south edge of the field rows of tomatoes, beans, okra, and New Era cowpeas were planted to test the degree to which the nematode infestation had been reduced by two years of these rotations. In the spring of 1909 another strip was sown to the same four kinds of plants, the remainder being planted with two varieties of cotton, viz, Triumph and Columbia. A similar area to the north of the rotation fields was also sown to the same sorts of cotton, while to the east was a field of Peterkin cotton belonging to a renter and not planted with reference to the experiment. The choice of the field to the north was made through an unfortunate misunderstanding. It was not discovered until the planting was done and the plants above the ground that that field too had undergone somewhat of a rotation, viz, 1906, cotton; summer of 1907, Iron cowpea; winter of 1907-8, rye; summer of 1908 , Iron cowpea; winter of 1908-9, rye. The field to the east, which was sown to Peterkin cotton, was in cotton for the third successive season.

The experiments were further interfered with by torrential rains which were harmful in two particulars, viz, they washed out much of the cotton and brought soil from nematode-infested fields and deposited it on parts of the rotation plats. 
The yields on the plats were as follows:

TABLE IV.- Yield of crops on four experimental plats at Monetta, S. C.

\begin{tabular}{|c|c|c|c|}
\hline Season and year. & Crop. & Actual yield. & $\begin{array}{c}\text { Yield } \\
\text { per acre. }\end{array}$ \\
\hline $\begin{array}{l}\text { Spring of } 1906 \ldots \ldots \\
\text { Fall of } 1906 \ldots \ldots \ldots \\
\text { Spring of } 1907 \ldots \ldots . \\
\text { Fall of } 1907 \ldots \ldots \ldots \\
\text { Spring of } 1908 \ldots \ldots \\
\text { Fall of } 1908 \ldots \ldots \ldots \\
\text { Spring of } 1909 \ldots \ldots\end{array}$ & 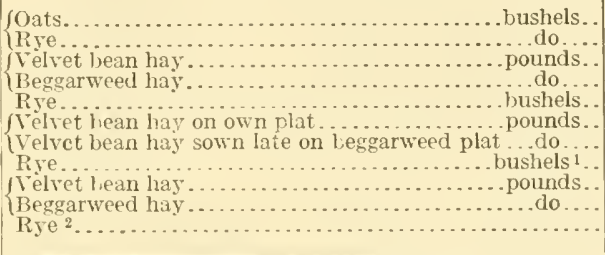 & $\begin{array}{l}\text { About } 4,900 \\
\text { About } 1,575 \\
10 \frac{1}{4} \\
\text { About } 1,600 \\
\text { About } 730 \\
\text { About } 3,840 \\
\text { About } 560\end{array}$ & $\begin{array}{r}5.42 \\
11,300 \\
5,000 \\
14 \\
3,700 \\
2,300 \\
14 \\
8,850 \\
1,770 \\
\end{array}$ \\
\hline
\end{tabular}

$120 \frac{1}{2}$ bushels on $1 \frac{1}{2}$ aeres; therefore estimated at $10_{1}^{1}$ bushels for that field, 0.752 acre. 2 Cut before ripening to allow cotton to be planted.

At the prices current at Monetta, S. C., for hay (about $\$ 1 S$ per ton) and grain (\$3 per bushel in 1909 for seed, but here estimated at $\$ 1$ per bushel) the value of the hay produced in the three years amounted to about $\$ 117$ and that of the grain to $\$ 22.50$, a total of $\$ 139.50$, at the rate per acre of $\$ 156, \$ 30$, and $\$ 186$, respectively, an average of $\$ 62$ per acre per year. While these yields are probably considerably more than enough to pay for working the land and the rent of the land besides, as well as payment for the seed, velvet beans having cost about $\$ 4$ per bushel, it must not be concluded that the experiment was a failure in that the yields were not greater, for the primary purpose of the rotation was to reduce the nematode infestation while improving the land, or at least keeping it from deteriorating, and yet to make enough money to pay for the labor and seed used.

To test to what extent, if any, the land was improved was the purpose of planting a plat of cotton at the north of the rotation plat. Unfortunately, so many plants in each section were washed out by the heavy rains that a very poor stand was obtained, with the result that the yield per acre on the rotation and check plats could not be determined. The yields of the unginned cotton on the rotation plat were at the rate of 1 pound of cotton for 6 plants of Triumpl and 6.1 plants of Columbia, while on the control plat to the north it took 6.9 and 7.25 plants, respectively, to make a pound. The Peterkin plants to the east were not half as large and yielded even less.

The soil which at the beginning was very poor in humus, so poor in fact that the rye would scarcely grow and the oats did not pay for cutting, gave a much better appearing field of rye the following years. The foliage of the cotton on it had a good color, showing that the leguminous crops had increased the nitrogenous content of the soil. 
From the standpoint of nematode extermination the results were very satisfactory. Both in 1908, after two years of this rotation, and in 1909, after three years, the susceptible plants on part of the plat remained free from root-knot except as specified below. These plants were, as in previous tests, tomatoes, okra, beans, and New Era cowpeas, all extremely susceptible to root-knot attacks. Several rows of each were planted in 1908 along the southern edge of the plat, and in 1909 on the part just adjacent to that on the southern part of that portion of the field which had had a rotation of three years. Every plant was carefully lug up and all its roots examined after freeing them from the adhering soil. Every such plant was recorded as free, slightly affected, or seriously affected, a separate record being kept of all the plants in each hill.

The field slopes very gradually toward the south from higher, somewhat nematode-infested land on the north. Two slight depressions lead somewhat diagonally from the northwest to the southeast. In the spring of 1908 and again in the early summer of 1909 Monetta was visited by torrential rains which flooded and very badly washed the fields. Considerable soil from the fields to the north, and especially the badly infested field to the west, was washed down these depressions, settling on them and in the lower (southern) edge of the rotation field. Where these deposits of dirt occurred, and confined to these areas, some of the plants showed more or less nematode injury, most near the middle and least along the edges of the depressions. Furthermore, a few plants at the edges of the field, i. e., at the east and west ends of the rows, showed nematodes where they were probably introduced from the adjoining land in cultivating, plowing, etc. All the rest of the plants remained nematode free, although this field was badly infested before the experiment began.

In accordance with suggestions of the writer, Mr. A. D. Jackson, of Denison, Tex., made some rather similar experiments, using Iron cowpeas and rye as his rotation. Certain fields were very badly infested, so badly, indeed, that the crops on them were almost a total failure. By growing the cowpeas two seasons with rye as the winter crop the nematodes were so reduced in number that only 20 hills of cantaloupes out of half an acre were affected with rootknot and the crop of melons was excellent. Under date of July 10, 1909, Mír. Jackson wrote as follows:

I am well pleased with the Iron pea. While I have not eradicated the pest entirely by growing the pea two seasons, I have enriched my soil, have grown a large crop of feed, and the succeeding crop of vegetables has not in any case been materially affected (by nematodes).

In Mr. Jackson's fields the writer's and Mr. Jackson's conclusions were that the few nematodes surviving were those that were pro- 
duced on the few weeds whose presence it was impossible absolutely to prevent in the cowpeas. Thus, the weed known as careless weed (Amaranthus sp.) was found to have root-knot in the field of Iron cowpeas the second season these were grown.

Mr. Jackson also made the experiment of using summer fallow in combination with winter rye, as follows: The preceding crop was taken off the summer of 1906 , being badly knotted. The field was then kept in bare fallow from August, 1906, until the fall of 1907, when it was sown to rye. This was turned under when about mature, and in July, 1908, the field was sown to tomatoes (which are especially susceptible to root-knot). A fine crop of tomatoes resulted, the only nematodes present being in a small part of the field where Irish potatoes were badly attacked in 1906 and where volunteer potatoes came up in 1907. The remainder of the field remained free the succeeding year also (1909).

Prof. P. H. Rolfs ${ }^{1}$ recommends letting the field grow up to crabgrass (Syntherisma sanguinalis) after the crops are removed, first taking up and burning or otherwise destroying the plants to avoid infection from them. According to him this method when used even for only one year greatly reduces the number of nematodes present. Dr. Neal ${ }^{2}$ recommended the use of beggarweed, Japan clover, or Mexican clover. Regarding the latter the present writer knows nothing, but the first two are practically, if not entirely, immune and so ought to be valuable for this purpose.

This method was used with complete success by Schroeder ${ }^{3}$ in Germany against the stem nematode (Tylenchus dipsaci) after all other practicable methods had failed. He planted infected fields for a series of years with crops not susceptible to the nematode. After this period the fields gave again their normal yields of susceptible plants.

\section{RECOMMENDATIONS FOR FREEING A FIELD FROM ROOT-KNOT.}

In view of the results of the experiments described, the writer would make the following recommendations for freeing a field from root-knot. If the situation is one where the winters are cold and cool weather sets in in October, it will not be necessary to give attention to the subject during the fall and winter or in the spring before the ground begins to warm up. Under such conditions it would probably suffice to plow the land in the autumn, so as to have it in good condition for as early planting as possible in the spring. In the spring the field should be kept free from vegetation by cultivation or harrowing until the ground is warm enough to plant cowpeas. The field should then be planted thickly with Iron cowpeas, this

$$
{ }^{1} \text { Rolfs, 1898. } \quad{ }^{2} \text { Neal, } 1889 . \quad{ }^{8} \text { Schroeder, } 1902 .
$$


variety being usually sufficiently resistant to the root-knot to permit its use for this purpose. In the fall this can be cut for seed or hay. The ground should then be plowed up and the process repeated the next season. Except in exceedingly bad infestations, two seasons devoted to Iron cowpeas should be sufficient to free the land from the pest. If desired, some winter grain, preferably rye or perhaps wheat, may be sown in the fall, the cowpeas not being planted until the crop is harvested early the next summer, following them by grain again. Where the weather remains warm rather late in the fall it would be desirable always to do this and so prevent the growth of weeds which might harbor the nematode in the fall and winter. Where the summer is long enough, velvet beans or Florida beggarweed are perhaps preferable to cowpeas, as they give a denser growth that more completely smothers out all weeds. Special care must be taken that in the summer time no weeds are allowed to grow in the field, as it will be seen by reference to the list of susceptible plants that many of the common weeds harbor the nematode. Their presence in the field, therefore, would serve to perpetuate rather than kill the nematode.

Where practicable, the surest results can be attained by keeping the ground absolutely bare of all vegetation for two years. This can not be done on some soils, owing to the danger of the destruction of humus by the hot sun or of washing by heavy rain.

Where the field is free from roots of perennial plants which might shelter the pest and is so situated that it can be submergerl easily for long periods, it may pay to flood the land for three or four weeks, or perhaps during the winter. This would be impracticable except in a few locations. Furthermore, in many soils it would leach out all the plant food and make the soil poor, but where an impermeable layer will hold the water and keep it from leaching out it is conceivable that this method might be found very satisfactory. A short period of flooding or attempting to do this while the soil contains perennial roots containing the nematode will hardly prove successful.

In the irrigated districts of the West, special care should be taken to avoid the introduction of this nematode into lands devoted to potato raising. To this end only perfectly sound, clean potatoes should be used; no potatoes from suspected regions should be planted, even should the individual potatoes appear perfectly healthy, without a preliminary sterilization with formaldehyde solution to destroy any nematodes present in the adhering soil.

Should none of the foregoing methods be feasible, high fertilization, especially with that element (potassium calcium or phosphorus) which is most nearly deficient in the soil, will prove helpful, although it will not kill the nematodes. When, as is often the case in 
the sandy soils of the southern United States, the soils are already deficient in potash, rather strong applications of some of the potash fertilizers-for example, kainit, potassium magnesium carbonate, sulphate of potash, etc.-are very helpful. Care should be taken not to apply enough to prevent the germination of the seed.

\section{BREEDING STRAINS RESISTANT TO ROOT-KNOT.}

As already mentioned, Webber and Orton have shown ${ }^{1}$ that the Iron variety of cowpea is practically immune to root-knot and wilt (Neocosmospora vasinfecta), while most other sorts are exceedingly susceptible to both diseases. The latter investigator has continued his breeding experiments, using the Iron cowpea as one of the parents, and has produced several varieties more prolific than that sort in which the resistant characteristics are present. Similarly in the breeding of tobacco, Shamel and Cobey ${ }^{2}$ obtained a strain resistant to nematodes. Certain sorts of figs-for example, Celeste and Poulette-are said to be less subject to injury by nematodes than other kinds. Among grapes, so far as the writer's observations go, the Old World species (Vitis vinifera) seems to be especially liable to injury by root-knot, although the different sorts vary greatly in their susceptibility. Thus, Zinfandel and Muscat appear very subject to this trouble, while Sultanina (erroneously called Thompson Seedless) is apparently not so easily injured. Some of the phylloxera-resistant hybrids and pure American sorts are practically immune to rootknot as well as to phylloxera, although some American sorts are quite badly affected by the nematode. These observations of the writer are confirmed by Lavergne, who states ${ }^{3}$ that the European varieties are very susceptible to Anguillula vialae, as he calls the root-knot nematode, while those of American origin that are resistant to phylloxera are also resistant to root-knot. Of the watermeloncitron hybrids bred by Mr. Orton with resistance to wilt as the main aim, it was found by the writer that of one strain only 4 out of 333 plants showed root-knot, i. e., 1.2 per cent, while in two other strains 28 and 51.9 per cent, respectively, showed root-knot. The presence of such marked differences shows that it would be entirely feasible to breed a watermelon variety that would be practically immune to root-knot as well as to wilt. Bouquet de la Grye ${ }^{4}$ points out that Coffea liberica is less susceptible to root-knot than $C$. arabica and recommends grafting the latter upon the former. To obtain a firm union, this must be done by an approach graft with seedlings.

Simple selection can be and ought to be practiced by everyone who grows his own seed; more complicated breeding work, unless per-

1 Webber and Orton, 1902. ${ }^{2}$ Shamel and Cobey, 1907. 3 Lavergne, 1901. ' 4 Bouquet de la Grye, 1899. 
formed by men who can devote considerable time to it, hardly pays for the time and expense required.

In carrying out simple selection we must remember that no new character's are originated by this method. We simply select and strive to fix in one strain certain characters that are present as variations in the plants we are working with. Thus, if we find in a field badly infested with nematodes that a certain proportion of the plants are free from root-knot while the rest succumb, it would probably pay to begin selecting seed from the unaffected plants. It is better still if we can inbreed or intercross similar resistant plants. On the other hand, resistance to nematodes seems sometimes not to be one of the variations occurring in a plant. Such a plant can not be selected, as there is no foundation on which to build. However, by crossing it with some nearly related nonsusceptible sorts, some of the progeny may possibly show desirable qualities of resistance while at the same time preserving the best qualities of the parent sorts.

In all such breeding it must be borne in mind as a very important principle that this work should be done in badly infested fields. If naturally infested fields are not available, provision should be made to do this work where the disease is abundant.

No attempt will be made here to describe the methods of selection or hybridization. These are known to all seed growers and breeders. They can be found described in detail in many publications. ${ }^{1}$

Every farmer ought to be able at least to carry on this simple selection: When any plants in an infested field show special vigor and freedom from root-knot they should be marked and the seed collected before the main crop is gathered. This should only be done, however, if these resistant plants are also up to standard in all other features.

\section{SUMMARY.}

(1) The disease known as root-knot, characterized by enlargements of the roots and often leading to the death of the plant affected, is caused by a nematode (Heterodera radicicola (Greef) Müll.). This was probably originally native in the Tropies (of the Old World?), but has spread into nearly every part of both Temperate Zones.

(2) The plants recorded as more or less subject to attack number almost 480 species and varieties, including nearly all of the larger families of flowering plants. Probably many more are actually susceptible, but hare not been reported yet as hosts. Most of the important field and garden crops and ornamental plants are more or less subject to root-knot.

1 Hays, 1901; Bailey, 1906; Orton, 1909; Reed, 1909; Salmon, 1907; Spillman, 1909; Wilcux, 1963; Oliver, 1910. 
(3) The life cycle of this nematode, from egg to egg, may take place in four weeks, or longer, depending upon the temperature of the soil. The larval stage is that in which entry into the host takes place. It then becomes motionless and soon enlarges and undergoes a sort of metamorphosis, the males eventually recovering the original worm shape, while the females become pear or flask shaped and very much enlarged in their transverse dimensions. Each female lays 500 or more eggs. The winter is passed probably most frequently in the larral stage in the soil, but in the ease of galls on perennial roots the nematodes may overwinter in these in a more advaneed stage, even as practically mature and perhaps already fertilized females.

(4) For the rapid multiplication of the root-knot nematode the following conditions are necessary: (a) A certain degree of warmth of the soil. Thus, in southern Florida this nematode is active the year round, in part of South Carolina the active season is from April 20 or May 1 to the middle or end of October, while farther north the period is still shorter. (b) Loose-textured soil. Only sandy or at least light soil is favorable to its spread. (c) Moisture. The drying out of the soil is frequently fatal to the nematode and in any case prevents it from doing any harm. Apparently the moister the soil as long as it is well supplied with air, the more favorable it is to the nematode's development. However, wet soil, i. e., soil in which the air spaces are filled with water, is at length fatal to the nematode. (d) Food supply. The larvæ are able to exist in the soil for more than one year, but apparently not for two years, without the presence of living plants into which to enter. They are apparently unable to develop beyond the larval stage unless they enter a suitable host plant.

(5) The nematode is distributed in several ways: (a) The larva move through the soil by their own motion, but the distance traversed thus is probably not more than 6 feet or so a season. (b) They are carried from field to field in the earth clinging to implements, the hoofs of animals, the shoes of laborers, wagon wheels, etc. (c) They are conveyed in the soil that is washed from one field to another by heavy rains, a very common mode of distribution of this pest. (d) It is possible that heavy winds may carry larvæor oggs with the soil blown from one field to another, but probably most would be so dried out in the process that this is not much to be feared. (e) They are introduced into new places in the roots or in the dirt adhering to the roots of nursery stock, in rooted cuttings, potted plants, etc., especially those of the peach, grape, fig, mulberry, potato, ginseng, etc.; also in the dirt in which some seeds are packed. $(f)$ They are 217 
sometimes brought to a field in manure if the manure pile has stood on infested soil.

(6) The following methods of eontrol in greenhouses and seed beds may be used: (a) The most effieient method is the use of live steam at fairly high pressure. The steam is forced through a system of perforated pipes laid at the bottom of the bed or bench. (b) The old infested soil may be entirely removed and the benehes thoroughly cleaned out. Then noninfected soil may be put in its place. This method is not advisable in regions where the nematode occurs out of doors in the vicinity. (c) Infeeted soil, when it is desired to save it and steaming is impracticable, may be freed by allowing it to lie through the winter in a place where it will be exposed to alternate freezing and thawing, and especially to drying. (d) Soil containing perennial plants ean be nearly if not quite freed from nematcdes by the use of an abundanee of a solution of formaldehyde (1 part of commereial formaldehyde to 100 parts of water). This solution is fatal to many plants and ean be used only with great eaution.

(7) For the control of the nematode in the field where the land is occupied by perennial erops no entirely satisfactory ehemical applieation can be recommended. Places where trees are to be reset should be freed from nematodes by the use of earbon bisulphid at a rate of 3 or 4 ounces per square yard plaeed in about nine holes per square yard, these holes being about 6 to 12 inches deep and to be filled with dirt as soon as the chemical is placed in them. Carbon bisulphicl can not be used with safety around living trees. Flooding the land scems to be unsatisfactory, as flooding long enough to kill the nematodes is usually fatal to the trees. High fertilization and eonstant eultivation to induce growth often so help the trees that they are able, as it seems, to outgrow the trouble, the roots either penetrating to levels where the nematodes are less abundant or being formed faster than the galls ean be produced. Avoid growing susceptible eover crops, like the ordinary nonresistant varieties of cowpeas, for example, for these multiply the nematodes in the soil manyfold. In preparing the land for setting out a perennial crop the soil should be freed from nematodes by the use of the methods suggested below.

(\$) For land infested with nematodes and not bearing a perennial crop, the following methods may be recommended: (a) Keeping the land free from vegetation of all kinds for two years. This is the most effeetive method, but it is not practicable in many eases. (b) Planting the land to nonsusceptible erops for at least two (perhaps better three) years, using in the winter small grains, such as wheat, rye, or oats, and in the summer the velvet bean, Florida beggarweed, the Iron cowpea, or even peanuts, scrupulously destroying all weeds that might harbor the nematodes. (c) Making heavy applications of 
fertilizers, especially those containing potash, except where the soil already contains this in abundance. This treatment often reduces nematode injury greatly. (d) Flooding the land for a period of some weeks. (e) Where rain is not likely to interfere, plowing and allowing the soil to dry out for several months. ( $f$ ) Preventing, by the use of embankments, ditches, etc., the washing of soil from infested fields to the field which it is desired to free from the pest. The introduction of the pest by tools, wagons, farm animals, etc., should be avoided. The trap-crop methods and the use of various ehemicals have not proved practicable as tested by the writer. The former needs, perhaps, further trial.

(9) The ideal procedure is to develop nonsusceptible strains of plants, so that the expense and trouble of exterminating the pest may be avoided. Such strains may be obtained by the selection of more resistant plants or by crossing with resistant strains followed by the careful selection and breeding of the progeny.

NoтE.-While this bulletin was in press, there appeared a note in Science, ${ }^{1}$ by L. N. Hawkins, describing the occurrence of Heterodera radicicola in the roots of Typha latifolia near Ithaca, N. Y.

The writer has just received from Mrr. G. L. Fawcett, plant pathologist of the Porto Rico Experiment Station, Mayaguez, P. R., specimens of the bark near the base of a 15-year-old coffee tree. Mr. Fawcett writes: "The disease is characterized by a roughening of the bark at the base of the coffee tree, extending from the surface of the soil upward for a foot or two. No doubt it injures the tree, but such injury must be slight. I have seen no sick tree the bad condition of which could clearly be ascribed to this nematode; only a small percentage of the trees in any plantation are infested. It is perhaps more common in moister and more shady places. Older trees, say, those of 15 years or more, are the only ones noticed with this disease." The living portion of the cortex was found to be very densely infested with mature females of Heterodera radicicola. It seems probable that these nematodes must have passed upward through the soft tissue of the cortex from some original infection in the root. It is worthy of note that sometimes in herbaceous plants, such as tomato, the writer has found nematodes 6 inches or more above the level of the ground within the cortical tissue of the stem. 


\section{BIBLIOGRAPHY.}

Papers seen by the author are indicated by an asterisk (*). All not so marked have been accepted on the authority of other writers. Only those titles to which reference has been made in the text are included in this list. This is not, therefore, a complete bibliography of all papers pertaining to this nematode.

Аввеу, G. Eelworm destruction. Journal of Horticulture, London, ser. 3, vol. 36, January 6, 1898, p. 16.

- Eelworm in vine roots. Journal of Horticulture, London, ser. 3, vol. 38, January 5, 1899, pp. 14-15, figs. 3-4.

* Atkinson, George F. A preliminary report upon the life history and metamorphoses of a root-gall nematode, Heterodera radicicola (Greeff ${ }^{1}$ ) Müll., and the injuries caused by it upon the roots of various plants. Science Contributions from the Agricultural Experiment Station, Alabama Polytechnic Institute, Auburn, Ala., vol. 1, no. 1, December, 1889; Bulletin of Agricultural Experiment Station, n. s., no. $9,1889,54$ pp., 6 pls.

* _ Diseases of cotton, Bulletin 33, Office of Experiment Stations, U. S. Dept. of Agriculture, 1896, pp. 279-316.

* Bailex, L. H. Some troubles of winter tomatoes. Bulletin 43, Cornell Agricultural Experiment Station, 1892.

* ___ Plant-breeding; being six lectures upon the amelioration of domestic plants, 4th ed., New York, 1906, 483 pp., illustrated.

BAKER, H. Employment for the microscope, London, 1753, chap. 4, p. 250.

Barber, C. A. A tea-eelworm disease in South India. Department of Land Rec. ords and Agriculture, Madras, Agricultural Branch, vol. 2, Bulletin 45, 1901, pp. 227-234, 3 pls.

* Berkeley, M. J. Vibrio forming cysts on the roots of cucumbers. Gardeners' Chronicle, London, 1855, p. 220, 2 figs.

* Bouquet de la Grye. La régénération des plantations de caféiers dans les Antilles. Bulletin des Séances de la Société Nationale d'Agriculture de France, Paris, vol. 59, 1899, pp. 683-687.

* Breda de HaAN, J. van. Levensgeschiedenis en bestrijding van het tabaks-aaltje (Heterodera radicicola) in Deli. Mededeelingen uit 's Lands Plantentuin, Batavia, 1899 , no. 35 , pp. 1-69, 3 pls.

*___ Wortel-ziekte bij de peper op Java. Verslag omtrent den Staat van 's Lands Plantentuin te Buitenzorg over het Jaar 1904, Batavia, 1905, pp. 21-39.

* Brick, C. Bericht über die Tätigkeit der Abteilung für Pflanzenschutz für die Zeit vom 1 Juli, 1904, bis 30 Juni, 1905. Jahrbuch der Hamburgischen Wissenschaftlichen Anstalten, vol. 22, 1904, p. 299-311. 1905.

Casali, C. L'Heterodera radicicola Greef nelle radici del nocciuolo. Giornale di Viticoltura e di Enologia, vol. 5, 1898, p. 4.

Снifflot, J. La maladie noire des clématites à grandes fleurs causée par l' "Heterodera radicicola Greeff." 1 Semaine Horticole, 1900, pp. 535-537. Bulletin de la Société des Sciences Naturelles de Saone-et-Loire, n. s., vol. 6, 1900, pp. 128-134. 
* Совв, N. A. Tylenchus and root-gall. The Agricultural Gazette of New South Wales, Sydney, 1890, vol. 1, pp. 155-184, figs. 1-8, pl. 4.

* __ Root-gall. The Agricultural Gazette of New South Wales, September, 1901, vol. 12, no. 9, pp. 1041-1052, figs. 1-8.

* ___ The internal structure of the gall-worm. The Agricultural Gazette of New South Wales, Sydney, October, 1902, vol. 13, no. 10, pp. 1031-1033, fig. 1.

* Cornu, Maxime. Sur une maladie nouvelle qui fait périr les Rubiacées des serres chaudes (Anguillules). Comptes Rendus Hebdomadaires des Séances de l'Académie des Sciences, Paris, vol. 88, 1879, pp. 668-670. (1879-1.)

* __ Études sur le Phylloxera vastatrix. Mémoires Présentés par Divers Savants à l'Académie des Sciences de l'Institut de France et Imprimés par son Ordre, Paris, ser. 2, vol. 26, 1879, pp. 1-357, pls. 1-24. (1879-2.)

* Craner, P. J. S. Nematoden in robusta-koffie. Teysmannia, vol. 17, no. 3, 1906, pp. 191-192.

Dalla Torre, K. W. von. Die Zoocecidien und Cecidozoen Tirols und Vorarlbergs. Berichte des Naturwissenschaftlich-Medizinischen Vereines in Innsbruck, vol. 20, 1892, pp. 90-172.

* Darboux, G., and Houard, C. Catalogue systématique des Zoocécidies de l'Europe et du Bassin Méditerranćen, Paris, 1901, 544 pp., illustrated.

* Davaine, C.J. Recherches sur l'Anguillule du Blé niellé considérée au point de vue de l'histoire naturelle et de l'agriculture, Mémoire couronné par l'institut 1857, 80 pp., 3 pls. Also in Comptes Rendus des Séances et Mémoires de la Société de Biologie, Paris, 1856, ser. 2, vol. 3, pp. 201-271, pls. 1-3. 1857.

Delacroix, Georges. [Sur quelques maladies vermiculaires des plantes tropicales dues à l'Heterodera radicicola Greef.] L'Agriculture Pratique des Pays Chauds, vol. 1, 1901-1902, pp. 672-688; vol. 2, 1902-1903, pp. 80-88, figs. 1-2; pp. 135-143. Reviewed in Zeitschrift für Pflanzenkrankheiten, vol. 14, no. 5, November 1, 1904 , p. 311.

* Dorsetr, P. H. New diseases of the violet. The American Florist, vol. 15, September 30,1899 , pp. 246-248, figs. 1-5.

Ducomet, V. Le dépérissement des bois de Chêne-Liège en Gascogne. Bulletin Mensuel de l'Office de Renseignements Agricoles, Ministère de l'Agriculture [France], Paris, 7th year, 1908, pp. 285-299.

DYke, W. Root eelworms in tomatoes and cucumbers. Journal of Horticulture, London, ser. 3, vol. 35, December 9, 1897, pp. 547-548.

* Frank, A. B. [Galleu der Anguillula radicicola Greef an Soja hispida, Medicago sativa, Lactuca sativa und Pirus communis.] Verhandlungen des Botanischen Vereins der Provinz Brandenburg, year 23 (1881), Berlin, 1882, pp. 54-55.

* _ Ueber das Wurzelälchen und die durch dasselbe verursachten Beschädigungen der Pflanzen. Land wirthschaftliche Jahrbücher, vol. 14, 1885, pp. 149-176, pl. 3 .

* Die Krankheiten der Pflanzen; ein Handbuch für Land- und Forstwirte, Gärtner, Gartenfreunde und Botaniker, $2 d$ ed., vol. 3, Die tierparasitären Krankheiten der Pflanzen, 1896, chap. 2.

Galloway, B. T. Club root in roses. American Gardening, vol. 18, February 20, 1897, p. 127.

* Gándara, Guillermo. La anguilula del Cafeto. Comisión de Parasitología Agrícola, Mexico. Circular 51, 1906, 7 pp., 6 figs.

* Gilbert, W. IV. The root-rot of tobacco caused by Thielavia basicola. Bulletin 158, Bureau of Plant Industry, U. S. Dept. of Agriculture, 1909, 55 pp., 5 pls.

* Göldi, Emilio Augusto. Relatorio sobre a Molestia do Cafeeiro na Provincia do Rio de Janeiro. Archivos do Museu Nacional do Rio de Janeiro, vol. 8, 1892, pp. 7-123, pls. 1 to 4,1 map. 
* Greef, R. [Ueber die frei lebenden Nematoden (Anguillulinen).] Sitzungsberichte der Niederrheinischen Gesellschaft für Natur-und Heilkunde zu Bonn. Sitzung vom 6 December, 1864, pp. 112-113. Verhandlungen des Naturhistorischen Vereines der Preussischen Rheinlande und Westphalens, vol. 21, 1864.

* U_ Ueber Nematoden in Wurzelanschwellungen (Gallen) verschiedener Pflanzen. Sitzungsberichte der Gesellschaft zur Beförderung der Gesammten Naturwissenschaften in Marburg, 1872, pp. 172-174.

Gvozdenović, Franc. Pflanzenkrankheiten und Schädlinge. Bericht über die Tätigkeit der K. K. Landwirtschaftlich-Chemischen Versuchsstation in Spalato im Jahre 1902, pp. 8-10.

* Halsted, Byron D. Nematodes as enemies to plants. Report of the Botanical Department. Eleventh Annual Report of the New Jersey Agricultural Experiment Station for the year 1890, pp. 366-370. 1891.

* Hays, W. M. Plant breeding. Bulletin 29, Division of Vegetable Physiology and Pathology, U. S. Dept. of Agriculture, 1901, 72 pp., 6 pls., 21 figs.

Henning, Ernst. De vigtigaste å kulturväxterna förekommande nematoderna. Kongl. Landtbruks-Akademiens Handlingar och Tidskrift, Stockholm, 1898, vol. 37 , pp. 247-265, 7 figs.

Hieronymus, G. Beiträge zur Kenntnis der europäischen Zoocecidien und der Verbreitung derselben. Jahresbericht der Schlesischen Gesellschaft für Vaterländische Cultur, vol. 68, 1890, Ergänzungsheft, pp. 49-272.

* Hook, James M. van. Diseases of ginseng. Bulletin 219, Cornell University Agricultural Experiment Station, June, 1904, pp. 163-186, figs. 18-42.

* Huergo, José M. (HIso). Enfermedad radicular del tomate. Boletín de Agricultura y Ganaderia, Republica Argentina, vol. 2, no. 42, 1902, pp. 1040-1059, 14 figs.

* E_Enfermedad radicular de la vid causada por la Heterodera radicicola ó Anguilula radicicola de Greef (Anguilulosis). Boletín del Ministerio de Agricultura, Buenos Aires, May, 1906, vol. 5, no. 1, pp. 29-56, 13 figs.

IGGULDEN, W. Combating eelworms and supporting plants. Journal of Horticulture, London, ser. 3, vol. 36, January 27, 1898, p. 76.

* JANSE, J. M. De aaltjes-ziekten van eenige cultuurplanten en de middelen ter harer bestrijding aangewend. Teysmannia, Batavia, vol. 3, 1892, pp. 475-4S8, 800-820.

* Jobert, C. Sur une maladie du Caféier observée au Brésil. Comptes Rendus Hebdomadaires des Séances de l'Académie des Sciences, Paris, vol. 87, 1878, pp. 941-943.

* Kamerling, Z. Verslag van het Wortelrot-Onderzoek, Soerabaia, 1903, 209 pp., $19 \mathrm{pls}$.

Kiefrer, J. J. Synopsis des Zoocécidies d'Europe. Annales de la Société Entomologique de France, vol. 70, 1901, pp. 233-579.

* Kühn, Julius, and Liebscher, G. Bericht über Versuche mit rübenmüden Böden, welche im Jahre 1879 in mehreren Wirthschaften der Provinz Sachsen ausgef ührt wurden. Neue Zeitschrift für Rübenzucker-Industrie, vol. 4, 1880, pp. 1-8.

* Küнм, J. Die Ergebnisse der Versuche zur Ermittelung der Ursache der Rübenın̈̈digkeit und zur Erforschung der Natur der Nematoden. Berichte aus dem Physiologischen Laboratorium und der Versuchsanstalt des Landwirthschaftlichen Instituts der Universität Halle, no. 3, 1881, pp. 1-153, pls. 1-3.

* ___ Die Wirksamkeit der Nematoden-Fangpflanzen nach den Versuchsergebnissen des Jahres 1881, op. cit., no. 4, 1882, pp. 1-14, 1 fig.

* ___ Bericht über weitere Versuche mit Nematoden-Fangpflanzen, op. cit., vol. 2, no. 6, 1886, pp. 163-175. (1886-1.)

* __ Anleitung zur Bekämpfung der Rübennematoden, op. cit., vol. 2, no. 6, 1886, pp. 176-184, pl. 3. (1886-2.) 
* KüHs, J. Neuere Versuche zur Bekämpfung der Rübennematoden. ('entralblatt für Bakteriologie und Parasitenkunde, vol. 9, 1891, pp. 563-566 and 593-597.

Lagerheim, N. G. von. Baltiska zoocecidier. Arkiv för Botanik, Upsala, 1905, vol. 4, no. 10, pp. 1-27, pl. 1.

* Lavergne, Gaston. L'anguillule du Chili (Anguillula vialæ). Revue de Viticulture, vol. 16, 1901, pp. 445-452, figs. 75-83.

* Licopoli, G. Sopra alcuni tubercoli radicellari continenti Anguillole. Rendiconto dell' Accademia delle Scienze Fisiche e Matematiche, Naples, 1875, vol. 14,pp. 41-42.

__ Le galle nella flora di alcune Province Napolitane, Naples, 1877, 4 pls.

* Lotsy, J. P. Eine amerikanische Nematodenkrankheit der Gartennelke. Zeitschrift für Pflanzenkrankheiten, vol. 2, 1892, pp. 135-136.

* Lounsbury, C. P. Gall-worms in roots of plants. An important potato pest. Circular 25, Cape of Good Hope Department of Agriculture, 1904.

Magnus, P. Ueber Wurzeln von Passiflora mit kleinen seitlichen Verdickungen, verursacht von Heterodera. Sitzungs-Bericht der Gesellschaft Naturforschender Freunde zu Berlin, November, 188s, no. 9, p. 170.

* Marcinowski, Katr. Parasitisch und semiparasitisch an Pflanzen lebende Nematoden. Arbeiten aus der Kaiserlichen Biologischen Anstalt für Land- und Forstwirtschaft, Berlin, 1909, vol. 7, no. 1, pp. 1-192, pl. 1, 76 figs.

May, J. N. Club roots. American Florist, vol. 3, April 15, 1888, p. 396.

* Lel worms affecting roses. American Florist, vol. 11, January 25, 1896, p. 649 .

* Molliard, Marin. Sur quelques caractères histologiques des cécidies produites par l'Heterodera radicicola Greff. ${ }^{1}$ Revue Générale de Botanique, vol. 12, 1900, pp. 157-165, 1 pl., 1 fig.

* Mosser1, Victor. La maladie vermiculaire récemment observée en Égypte sur les bananiers, betteraves, etc., causée par l'Heterodera radicicola (Greef-Müller) avec une observation sur les Orobanches. Communication faite à l'Institut Égyptien au Caire, Cairo, 1903, 40 pp., 3 pls., 4 figs.

* Müller, Carl. Neue Helminthocecidien und deren Erzeuger. Inaugural dissertation, Berlin, 1883.

* _ Mittheilungen über die unseren Kulturpflanzen schädlichen, das Geschlecht Heterodera bildenden Würmer. Landwirthschaftliche Jahrbücher, vol. 13, 1884, pp. 1-42, pls. 1-4.

* Münter, Julius. Ueber Gicht oder das sogenannte Gichtig-oder Radigwerden (Nielle) des Weizens und anderer Grasfrüchte. Bulletin du Congrès International de Botanique et d'Horticulture, réuni à Amsterdam les 7, 8, 10 et 11 avril 1865, Rotterdam, 1866, pp. 420-429.

* Near, J. C. The root-knot disease of the peach, orange, and other plants in Florida, due to the work of Anguillula. Bulletin 20, Division of Entomology, U. S. Dept. of Agriculture, 1889, 31 pp., 21 pls.

Needham, John Turberville. An account of some new microscopical discoveries, London, 1745.

* ___ [Lettre en réponse au mémoire de Roffredi.] Observations sur la Physique, sur l'Histoire Naturelle et sur les Arts, par M. l'Abbé Rozier, vol. 5, 1775, pp. 226-228.

* Oliver, George W. New methods of plant breeding. Bulletin 167, Bureau of Plant Industry, U. S. Dept. of Agriculture, 1910, 39 pp., 15 pls.

* Orton, W. A. The wilt disease of the cowpea and its control. Bulletin 17, pt. 1, Bureau of Plant Industry, U. S. Dept. of Agriculture, 1902, pp. 9-22.

* __ The development of farm crops resistant to disease. Yearbook, U. S. Dept. of Agriculture, for 1908, pp. 453-464, pls. 39-40. 1909.

1 The name Greef is misspelled, as shown in the title of the paper cited.

$91294^{\circ}-$ Bul. $217-11-6$ 
* Ostermalder, Adolf. Nematoden als Feinde des Gartenbaues. Gartenflora. Zeitschrift für Garten- und Blumenkunde, vol. 50, 1901, pp. 337-346, pl. 1488, 1 fig.

Peglion, V. Malattia del Cyclamen cagionata da Heterodera radicicola. L' Italia Agricola, Milan, 1902, vol. 39, pp. 444-445, 1 pl.

Queva, C. Modifications anatomiques provoquées par l'Heterodera radicicola Müll. dans les tubercles d'une Dioscorée. Association Française pour l'Avancement des Sciences, Paris, Compte Rendu, session 23, 1894, pt. 2, pp. 629-633, figs. 1-4. 1895.

* Reed, George M. The development of disease-resistant plants. Second Annual Report, Missouri State Board of Horticulture, 1908, pt. 2, pp. 284-296. 1909.

* Ritzena Bos, J. L'Anguillule de la tige (Tylenchus devastatrix Kühn) et les maladies des plantes dues à ce nématode. Archives du Musée Teyler, ser. 2, vol. 3, 1892, pp. 161-348, 545-58s, pls. 1-10, 3 figs.

* —_L Les nématodes parasites des plantes cultivées. Sixième Congrès International d'Agriculture, Paris, 1900, Compte Rendu des Travaux, vol. 2, pp. 306-312.

* Rolfs, P.H. Report of the botanist and entomologist, Florida Agricultural Experiment Station, annual report, 1893. Bulletin 24, January, 1894, pp. 16-19, figs. 1-5.

* - Diseases of the tomato. Bulletin 47, Florida Agricultural Experiment Station, September, 1898, pp. 145-146.

Ross, Hermann. Beiträge zur Anatomie abnormer Monocotylenwurzeln (Musaceen, Bambusaceen). Berichte der Deutschen Botanischen Gesellschaft, vol. 1, 1883, pp. 331-338, pl. 10.

Rudv, W. N. Killing grubs in soil. The American Florist, vol. 9, September 28, 1893, p. 171.

Sacmon, E. S. On raising strains of plants resistant to fungus disease. Report of Third International Conference on Genetics, 1906, pp.378-384, 2 diagrams. London, 1907.

Schlechtendal, D. H. R. von. Beiträge zur Kenntnis der Pflanzengallen. (Sammelberichte aus den Jahren 1884-1885.) Jahresbericht des Vereins für Naturkunde zu Zwickau in Sachsen, 1885, pp. 1-23, pls. 1-2. 1886.

Schroeder, C. Das Stockälchen (Tylenchus devastatrix). Zeitschrift der Landwirtschaftskammer für die Provinz Schlesien, year 6, 1902, pp. 579-580.

* SeLby, A. D. Investigations of plant diseases in forcing house and garden. Bulletin 73, Ohio Agricultural Experiment Station, December, 1896, pp. 221-246, 4 pls., 5 figs.

* _ Soil treatment for the forcinghouse. The control of rosette (Rhizoctonia) in lettuce and tomatoes and of nematodes in crops grown under glass. Circular 57, Ohio Agricultural Experiment Station, 1906, 7 pp.

* Shamel, A. D., and Cobey, W. W. Tobacco breeding. Bulletin 96, Bureau of Plant Industry, U. S. Dept. of Agriculture, 1907, 72 pp., 10 pls., 14 figs.

* Sheldon, John I. Nematode galls on clover roots. The West Virginia Farm Review, February, 1905, vol. 13, no. 2, p. 42.

* Sorauer, P. Handbuch der Pflanzenkrankheiten, vol. 3, 1906.

SpIllman, W.J. Application of some of the principles of heredity to plant breeding. Bulletin 165, Bureau of Plant Industry, U. S. Dept. of Agriculture, 1909, 74 pp., 6 figs.

StrFt, A. Bekämpfung der Rübennematoden durch Ueberflutung des Feldes. Wiener Landwirtschaftliche Zeitung, vol. 53, 1903, pp. 621-622.

* __ Ueber im Jahre 1907 veröffentlichte bemerkenswerte Arbeiten und Mitteilungen auf dem Gebiete der Zuckerrüben- und Kartoffelkrankheiten. Centralblatt für Bakteriologie, Parasitenkunde und Infektionskrankheiten, pt. 2, vol. 21, 1908, no. 4-6, pp. 117-143.

217 
* Srone, G. E. Freezing, steaming and drying soil to destroy eel worms. The American Florist, vol. 15, August 12, 1899, pp. 32-33.

* Stone, G. E., and Sмrth, R. E. Nematode worms. Bulletin 55, Hatch Experiment Station of the Massachusetts Agricultural College, November, 1898, 67 pp., $12 \mathrm{pls}$.

* Strubell, Adolf. Untesuchungen über den Bau und die Entwicklung des Rübennematoden Heterodera schachtii Schmdt. Bibliotheca Zoologica. Originalabhandlungen aus dem Gesammtgebiete der Zoologie, herausgegeben von Dn Rud. Leuckart und Dr. Carl Chun, vol. 2, 1888, 52 pp., 2 pls.

* Sturgis, William C. Report of the Mycologist. Annual report of the Connecticut Agricultural Experiment Station for 1892, pp. 36-49. 1893.

* Tarnani, J. Ueber Vorkommen von Heterodera schachtii Schmidt und H. radicicola Müll. in Russland. Centralblatt für Bakteriologie Parasitenkunde und Infektionskrankheiten, pt. 2, vol. 4, 1898, pp. 87-89.

* Tischler, G. Ueber Heterodera-Gallen an den Wurzeln von Circaea lutetiana L. Berichte der Deutschen Botanischen Gesellschaft, vol. 19, 1901, Generalversammlungs-heft, 1902, pp. 95-107, pl. 25, and 1 text figure.

* Trelease, ITrliam. A nematode disease of the carnation. The American Florist, vol. 9, March 1, 1894, pp. 680-681.

Treub, M. Onderzoekingen over sereh-ziek Suikerriet. Mededeelingen uit 's Lands Plantentuin, Batavia, 1885, no. 2, 39 pp.

Trotter, Alessandro. Intorno a tubercoli radicali di Datisca cannabina L. Nota preliminare. Bullettino della Società Botanica Italiana, 1902, pp. 50-52.

* __ Osservazioni e ricerche sulla "malsania" del Nocciuolo in provincia di Avellino e sui mezzi atti a combatterla. Redia, vol. 2, 1904, January, 1905, pp. 37-67. (1905-1.)

* __ Nuove osservazioni su Elmintocecidii italiani. Marcellia, vol. 4, 1905, pp. 52-54. (1905-2.)

* Voigr. [No title.] Sitzungsberichte der Niederrheinischen Gesellschaft für Naturund Heilkunde in Bonn, May 12 and July 7, 1890, pp. 66-74 and 93-98. Verhandlungen des Naturhistorischen Vereines der Preussischen Rheinlande Westfalens und des Reg.-Bezirks Osnabrück, vol. 47, 1890.

Warming, Eug. Knolddannelser paa Rødderne af Elymus arenarius. [In "Smaa biologiske og morfologiske Bidrag.' '] Botanisk Tidsskrift, Copenhagen, 1877-1879, ser. 3, vol. 2, pp. 93-96.

* Webber, H. J., and Orton, W. A. A cowpea resistant to root-knot (Heterodera radicicola). Bulletin 17, pt. 2, Bureau of Plant Industry, U. S. Dept. of Agriculture, 1902, pp. 23-38, pls. 5 and 6.

Wilcox, E. M. Plant breeding to secure resistant forms. Bulletin 123, Office of Experiment Stations, U. S. Dept. of Agriculture, 1903, pp. 117-118.

* Zimmermann, A. Het vorkomen van Nematoden in de wortels van sirih en thee. Teysmannia, vol. 10, 1899, pp. 230-236.

* _ De Nematoden des Koffiewortels II. De Kanker (Rostrellaziekte) van Coffea arabica. Mededeelingen uit 's Lands Plantentuin, Batavia, no. 37, 1900, 62 pp., 21 figs. 


\section{DESCRIPTION OF PLATES.}

Plate I. Stages in the development of Heterodera radicicola (Greef) Müll., etc. Figs. 1 and 2.-Eggs in two different stages of development, $X$ 350. Fig. 3.-Larva immediately after escaping from egg, $X$ 105. Fig. 4.-Anterior portion of same, $\times 410$. Figs. 5 to 8.-Developmental stages of larvæ before sexual differentiation is apparent, $\times 105$. Fig. 9.-Molt in which sexual differentiation first becomes apparent, female nematodes approaching sexual maturity, $\times 105$. Fig. 10. - Sexually mature female nematode, a somewhat more advanced stage than shown in figure $9, \times 105$. Fig. 11.-Posterior portion of sexually mature female nematode somewhat compressed, $\times 220$ : $a$, Anal opening; $b$, alimentary canal; $c$, genital opening; $d$, vagina; $e$, $e$, uteri; $f, f$, ovaries. Fig. 12.-Eggbearing female nematode, $\times$ 47: $a$, Alimentary canal; $b$, loop of uterus; $c$, genital opening. Fig. 13.-First visible stage in differentiation of the male nematode (compare with fig. 9 ), $\times 105: t, t$, Testis. Fig. 14.-Mature male still within larval skin, $X$ 85. Fig. 15.-Mature male, $\times$ 85. Fig. 16.-Anterior portion of adult male, showing spear and peculiar structure for guiding its movements, $\times 930$. Fig. 17. - Larva entering root of clover, $\times 100$. Fig. 18.Larva of Heterodera schachtii Schmidt just escaped from egg (compare fig. 3), $\times 105$. Fig. 19.-Anterior portion of same, $\times 435$.

Plate II. Fig. 1.-Root-knot on sugar beets grown at the Subtropical Laboratory, Miami, Fla. 1907. Photographed by E. A. Bessey. Fig. 2.-Root-knot on squash, from Beeville, Tex. 1904. Photographed by W. A. Orton.

Plate III. Fig. 1.-Root-knot on carrot, from Morrison, Ill. 1908. Photographed by W. W. Gilbert. Fig. 2.- Root-knot on red clover grown in a pot of sterilized soil inoculated with affected roots of Ipomoea syringaefolia, Subtropical Laboratory, Miami, Fla., 1908. Photographed by E. A. Bessey. 


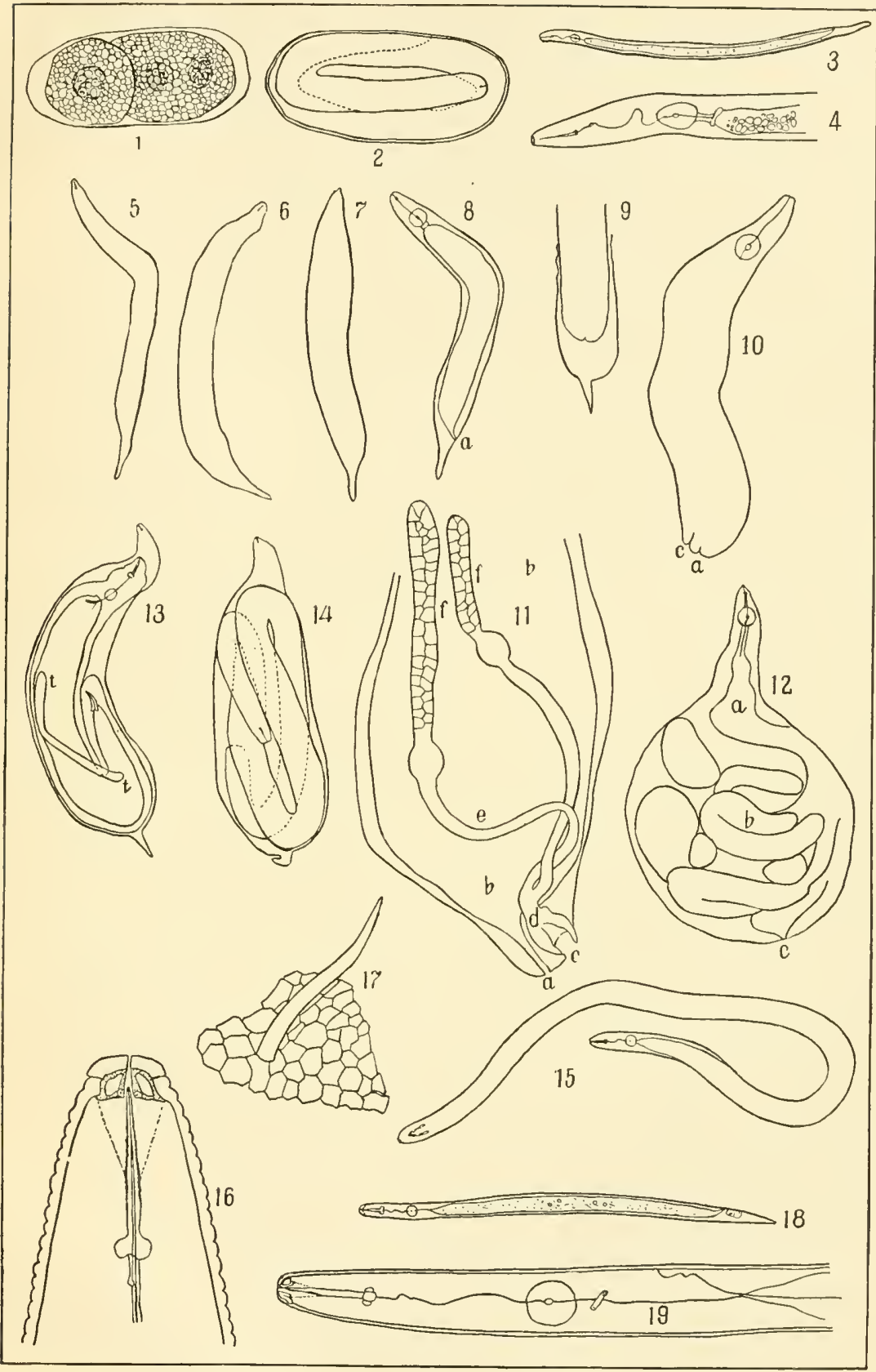

Stages in the Development of heterodera Radicicola (Greef) Müll., etc. 



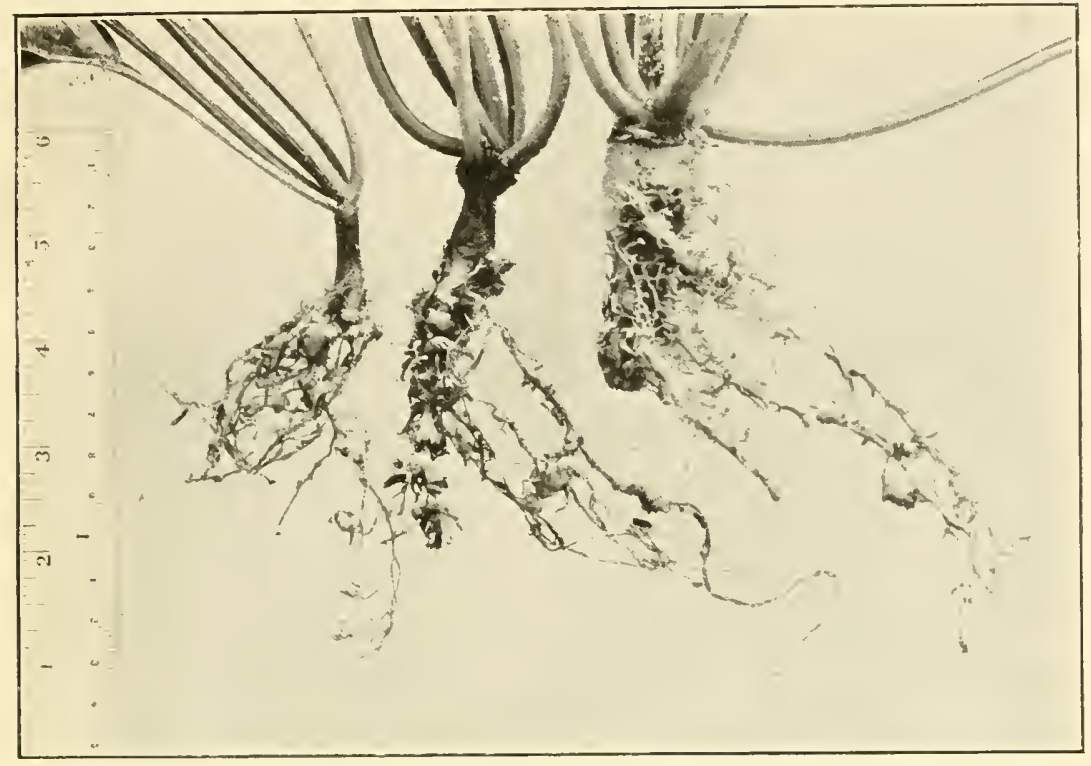

Fig. 1.-Root-Knot on Sugar Beet.

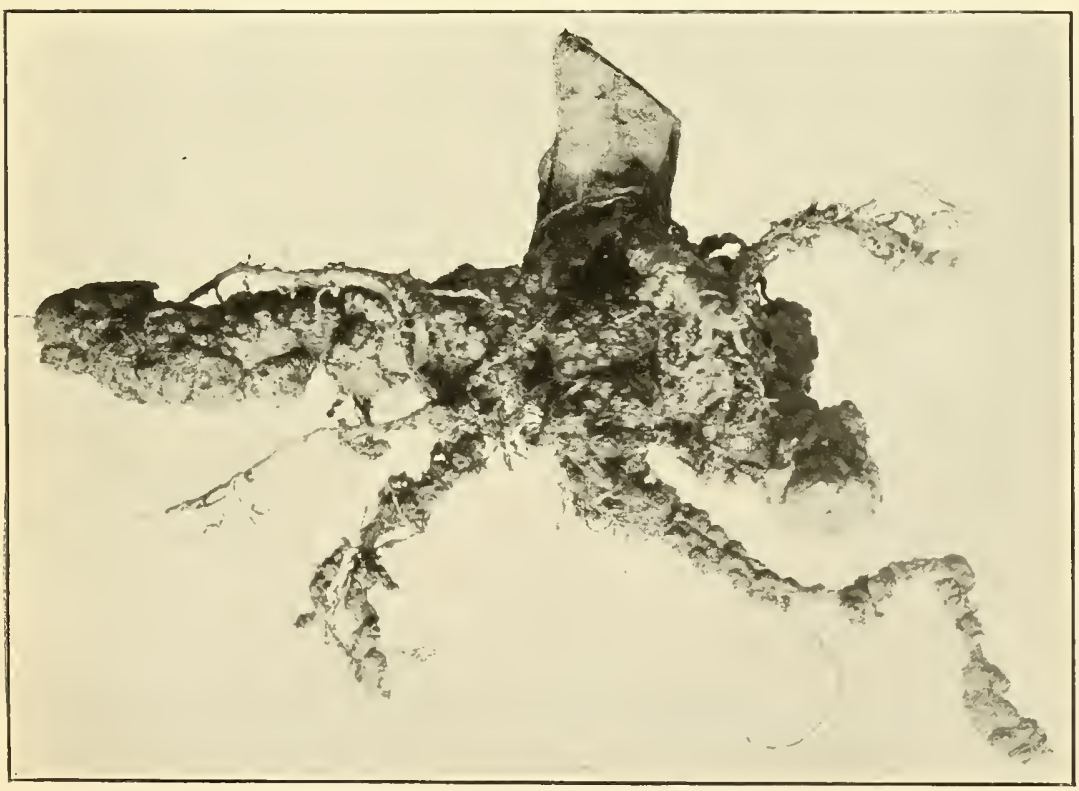

FIG. 2.-ROOT-KNOT ON SQUASH. 



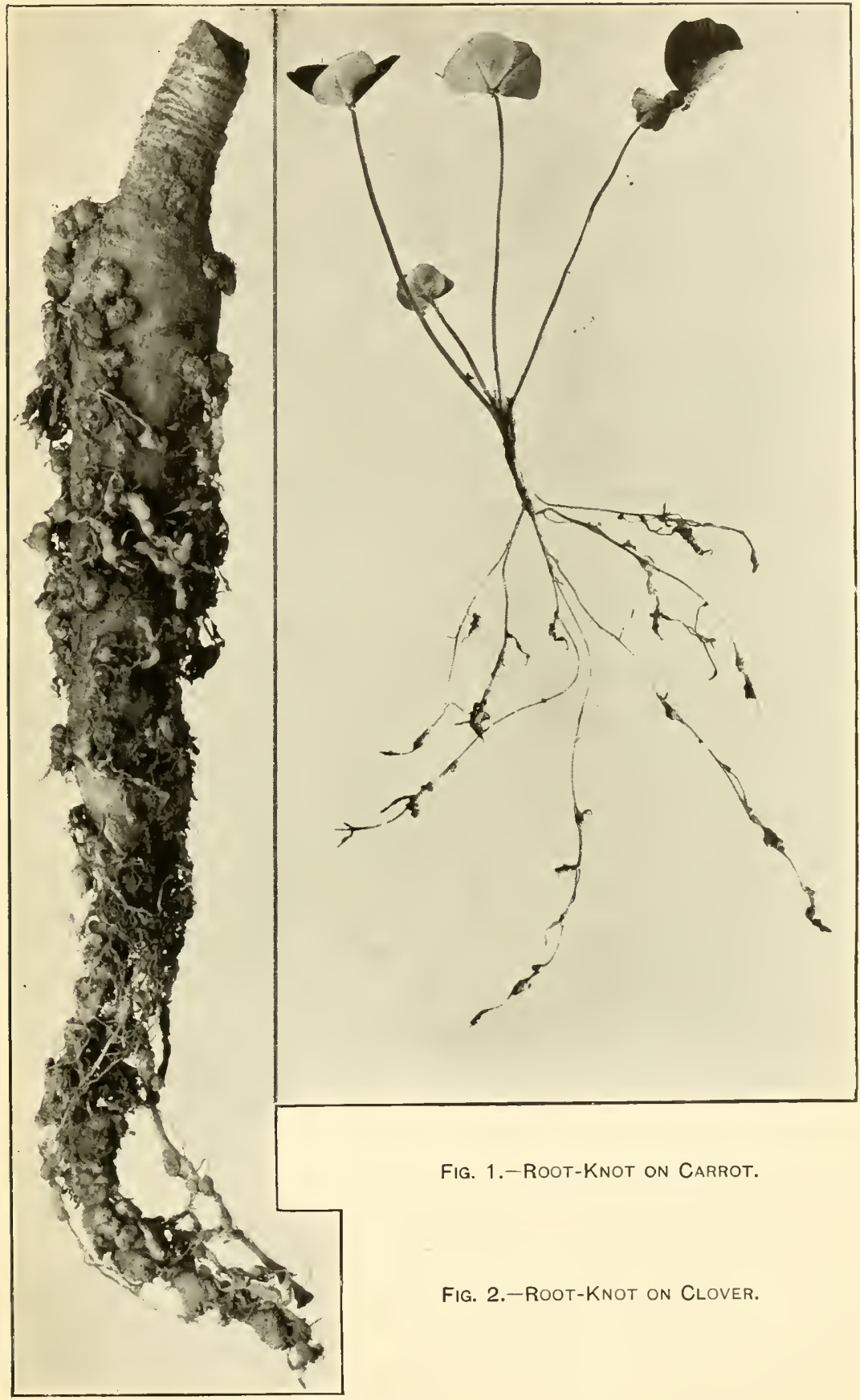





\section{N DEX.}

Page.

Abbey, G., on control of root-knot........................... $55-56,76$

Africa, German East, occurrence of root-knot.......................... . 23

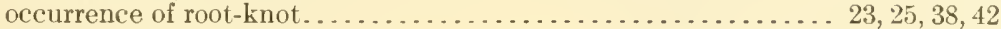

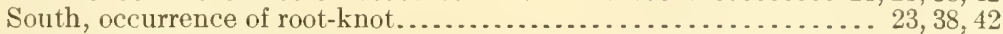
Agrostis alba. See Redtop.

Air, conditions favorable to root-knot. . . . . . . . . . . . . . . . . . . . . . . . . 42-44

See also Moisture, and Temperature.

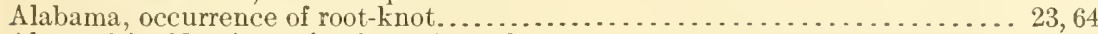

Alexandria, Va., investigations of root-knot....................... 47

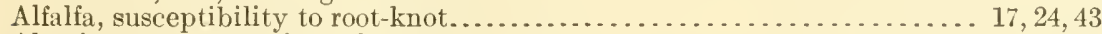

Algeria, occurrence of root-knot. . . . . . . . . . . . . . . . . . . . . . . 23

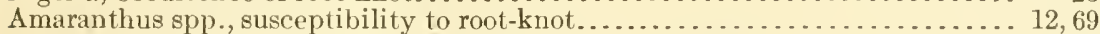

Ammonium silicofluorid, application for control of root-knot.............. . 55-56 sulphate, applicatiou for control of root-knot......... . 54-56,57,58

Andropogon spp., susceptibility to root-knot........................ 12,21

Anguillula spp., synonyms of parasite causing root-kpnot. . . . . . . . . 8,9,71

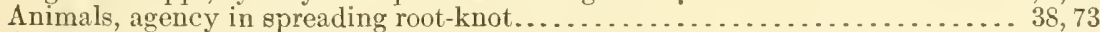

Aphelenchus sp., vitality tests............................... 30

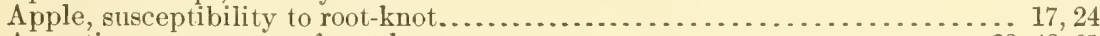

Argentina, occurrence of root-knot.......................... 23, 42,61

Arizona, occurrence of root-knot...................... $23,24,38,42,49,59$

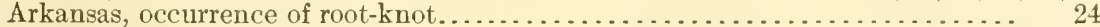

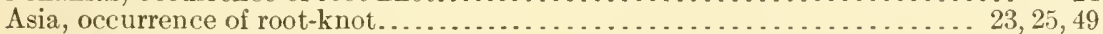

Asparagus, susceptibility to root-knot. . . . . . . . . . . . . . . . . 12,38 Atkinson, G. F., on root-knot......... 9, 11, 12, 13, 16, 17, 18, 19, 20, 32, 35, 36, 76

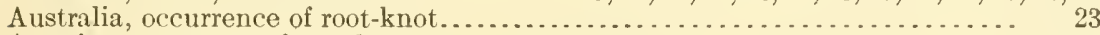

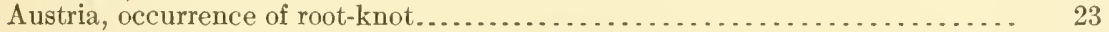

Bailey, L. H., on methods of control of root-knot.................43,72,76

Baker, H., on occurrence of nematodes.......................... . 30,76

Barber, C. A., on occurrence of root-knot. . . . . . . . . . . . . . 13, 14, 20,76

Barley, susceptibility to root-knot.............................. 16,21

Beaded root-knot. See Root-knot, beaded.

Bean, experiments for cuntrol of root-knot . . . . . . . . . . 54,55,56,57,62,66,68

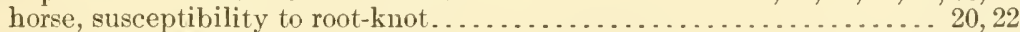

velvet, susceptibility to root-knot.............. 20,21, 65-67,70,74

Beet, sugar, affected with root-knot, analyses, study .................. $40-41$ nematode. See Heterodera schachtii.

susceptibility to root-knot................ 12,39,40-41,52,57,61, 82

tiredness, disease due to Heterodera schachtii . . . . . . . . . . . . . . . . 61

Beggarweed, Florida, resistance to root-knot............ . 17, 65-67,69,70,74

Berkeley, M. J., on occurrence of root-knot.................. 8, 14, 23, 76

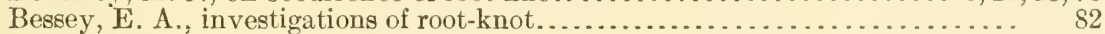

Bibliography, partial, of root-knot............................. $76-81$

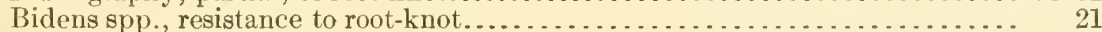

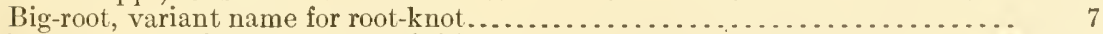

Bouquet de la Grye, on susceptibility of Coffea spp. to root-knot........ 14, 71, 76

Brazil, occurrence of root-knot............................... . . . . 23,49

Breda de Haan, J. van, on root-knot.......... 11, 12, 13, 14, 16, 17, 18, 19,54, 76

Breeding. See Root-knot, breeding resistant strains.

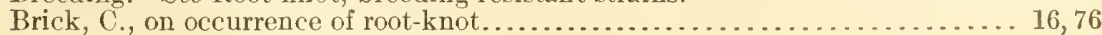

Bromus schraderi, resistance to root-knot...................... 21

Calcium carbid, use in experiments for control of root-knot. . . . . . . . . . 51,54 California, occurrence of root-knot. . . . . . . . . . . . 23, 24, 36, 38, 42, 49, 59 Cane, sugar, susceptibility to root-knot . . . . . . . . . . . . . . . . . . . 8,19 
Cape Colony, occurrence of root-knot. . . . . . . . . . . . . . . . . . . 23 Carbon bisulphid, use in experiments for control of root-knot.. 47, 49-50,51-52, 53, 74 Careless weed. See Amaranthus spp.

Carrot, susceptibility to root-knot . . . . . . . . . . . . . . . . . . . . 14, $\$ 2$

Casali, C., on occurrence of root-knot......................... 14,76

Catalpa, susceptibility to root-knot. . . . . . . . . . . . . . . . . . . . . . 13,22

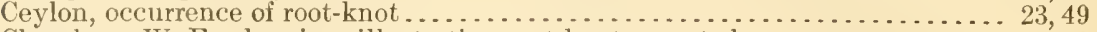

Chambers, WT. E., drawings illustrating root-knot nematode................ . 28,29

Chemicals, use in experiments for control of root-knot. . . . . . . . . 49-52, 53-56, 74

Chifflot, J., on occurrence of root-knot. . . . . . . . . . . . . . . . . . 14, 76

Chile, occurrence of root-knot......................... $9.23,42,61$

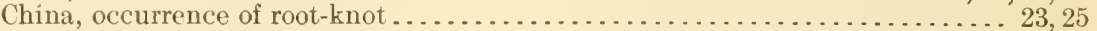

Climate, relation to root-knot . . . . . . . . . . . . . . . . . . 24, 42-44, 48, 73

Clover, Japan, resistance to root-knot. . . . . . . . . . . . . . . . . . . . . . 16, 69

Mexican, employmeut for reduction of root-knot................ 69

species resistant to root-knot . . . . . . . . . . . . . . . . . . . 63,69 susceptibility to root-knot................ 16, 17, 20, 22, 43, 69, 82

Club-root, variant name for root-knot........................... 8

Cobb, N. A., on root-knot.............. 9, 12, 19, 20, 28, 35, 38-39, 42, 61,77

Cobey, W. W., and Shamel, A. D., on strains of tobacco resistant to root-knot . 71, 80 Coffee, susceptibility to root-knot . . . . . . . . . . . . . 9, 14, 49,50, 60, 71,75

Colorado, occurrence of root-knot................................. 24,40

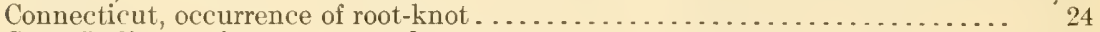

Corn, Indian, resistance to root-knot.............................. 21-22

Cornu, Maxime, on occurrence of root-knot . . . . . . . . 8, 14, 16, 17, 19, 20, 21, 77

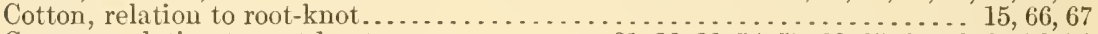

Cowpea, relation to root-knot.......... 21, 22, 23, 54-57, 62, 65, 66, 68-69, 70, 71

Crab-grass, susceptibility to root-knot...................... 21, 65, 69

Cramer, P. J. S., on occurrence of root-knot. . . . . . . . . . . . . . . . 14, 77

Crops, nonsusceptible, rotations for control of root-knot . . . . . . . . . . . 65-69, 74

perennial, root-knot, control in field................... 48-52, 74

trap, use in control of root-knot....................... $61-63,75$

Cucumber, susceptibility to root-knot...................... $14,22,59$

Dalla Torre, K. W. von, on occurrence of root-knot............... 12, 19, 77

Darboux, G., and Houard, C., on occurrence of root-knot. . . . . . . 13, 14, 16, 19, 77

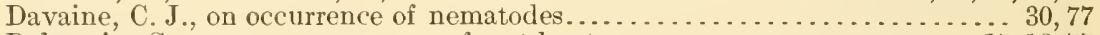

Delacroix, Georges, on occurrence of root-knot . . . . . . . . . . . . 17, 18, 77

Delaware, occurrence of root-knot. . . . . . . . . . . . . . . . . . . . . . . . . . 24

Dorsett, P. H., on occurrence of nematodes.................... 30,77

Drying, effect on root-knot, investigations... . 30, 37-38, 42-44, 45, 48, $60-61,73,74,75$

Ducomet, V., on occurrence of root-knot. . . . . . . . . . . . . . . . . . 19,77

Dyke, W., on control of root-knot ............................. 56,77

East Indies, occurrence of root-knot. . . . . . . . . . . . . . . . 23, 25, 49, 54

Echinochloa frumentacea. See Millet, Japanese.

Eelworm, variant name for nematode causing root-knot. . . . . . . . . . . . 7

Egg of root-knot nematode. See Heterodera radicicola, egg.

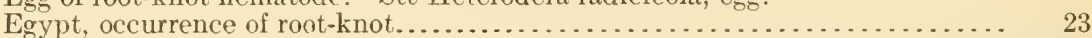

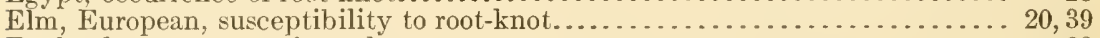

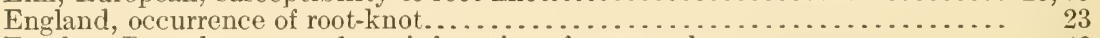

Escobar, Pomulo, on root-knot infestation of watermelon.............. 40

Euchlaena luxurians, resistance to root-knot. ...................... 21

Europe, occurrence of root-knot................................. 23

European elm. See Elm, European.

Eustachys petraea, unaffected by root-knot ......................... 21

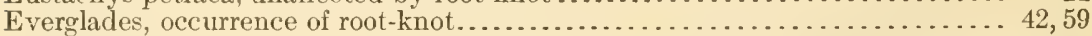

Experiments, cross inoculation, for testing adaptation of root-knot nema-

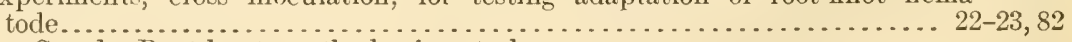

See also Root-knot, methods of control.

Fallow, bare, use in control of root-knot.................. 64, 69, 70,74

Fawcett, G. L., on root-knot infestation of the coffee tree............... 75

Fertilizers, use in control of root-knot in fields............. $52,56-58,70,74-75$

Fields, root-knot eradication and control ................... 48-71, 74-75 
Fig, relation to root-knot.

$15,22,23,24,36,38,49,71,73$

Flooding, method of control of root-knot.............. 42, 52, 58-60, 70, 74, 75

Florida beggarweed. See Beggarweed, Florida.

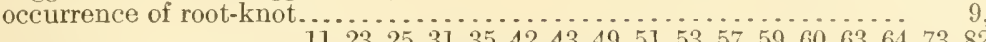

$11,23,25,31,35,42,43,49,51,53,57,59,60,63,64,73,82$ root-knot investigation. See Miami, Fla.

Formaldehyde, use in experiments for control of root-knot.... 46-48, 50-5I, 53-54, 74

Formalin. See Formaldehyde.

France, experiments for control of phylloxera.

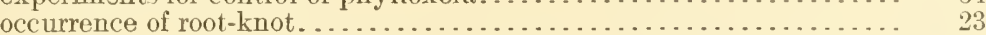

Frank, A. B., on root-knot........... 8, 12-20, 26, 37, 40, 41, 42, 43, 60, 62, 63, 77

Freezing. See Temperature.

Galloway, B. T., on occurrence of root-knot...................... 44, 77

Galls, root-knot, depth of occurrence in soil...................... 41,52

description............................ $7-8,39-41$

Gammie, G. A., on occurrence of root-knot.................. 13, 16, 17, 20

Gándara, Guillermo, on occurrence of root-knot............. 18, 50, 51, 54, 61, 77

Gardens, in Florida, root-knot investigations.......... 9-10,31, 43, 51, 53, 55, \$2

Georgia, occurrence of root-knot.............................. 23, 59, 64

Germau East Africa. See Africa, German East.

Germany, occurrence of root-knot or other nematodes........ \& $8,23,26,52,57,69$

Gilbert, W. W., on studies of root-knot..................... $63,77,82$

Ginseng, occurrence of root-knot................. 18, 22, 24, 38, 43,73

Gnaphalium purpureum, resistance to root-knot ................... 21

Göldi, E. A., on root-knot parasite of coffee.................... 9, 60, 77

Grains, relation to control of root-knot..................... 21-22, 74

See also Barley, Corn, Oats, Rye, Wheat, etc.

Gram, green, susceptibility to root-knot....................... 18, 22

Grapevine, relation to root-knot............ 21, 22, 23, 24, 36, 38, 49, 59, 61, 71,73

Grasses, relation to root-knot................ $8,11,12,13,14,15,18,21,65,69$

Greef, R., on occurrence of ront-knot................. $8,11,15,18,19,23,78$

Greenhouses, methods of control of root-knot................ 9, 24,44-48, 74

Grozdenović, Franc, on occurrence of root-knot......................... 13,78

Halsted, B. D., on occurrence of root-knot.................. 12, 19, 21, 78

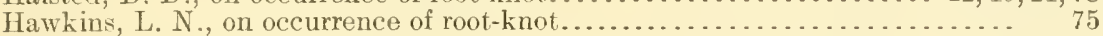

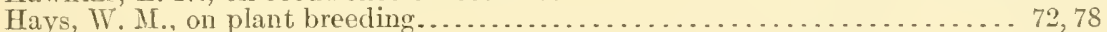

Helenium tennifolium, resistance to root-knot...................... ${ }_{21}$

Henning, Enst, on root-knot..................................... 18, 78

Heterodera javanica, synonym of $\mathrm{H}$. radicicola................. $8-9$ radicicola, cause of root-knot, life history, effects, etc.... 25-41,72,82 egg, description....................... 26-27, 73, 82 larva, description and habits........... 27-32, 34, 73, 82 mature forms, description........................... $32-36,82$ measurements of eggs, parts, ete.......... 26-29, 32-35, 37 molting........................... 31-32, 34, 32 original home............................... 25,72 overwintering................................. 36,73 similarity to II. sehachtii........... . $8,27,35,36-37,40-41$ synonymy......................... $8-9$

See also Root-knot.

schachtii, canse of disease of the sugar beet............. 8 ,

$25,27,35-37,39,40-41,52,57,58,61,82$

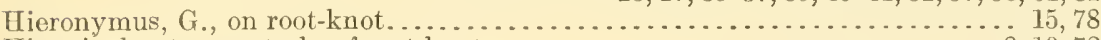

Historical notes on study of root-knot............................... $8-10,72$

Holland, occurrence of root-knot................................ ${ }_{2} 3$

Hollrung, on the effect of potash on sugar-beet nematodes.............. 57

Hook, J. M. van, on root-knot........................................ 18, 78

Hordeum vulgare. See Barley.

Horse bean. See Bean, horse.

Host plants. See Plants, host.

Houard, C., and Darboux, G., on occurrence of root-knot......... 13, 14, 16, 19, 77 Huergo, J. M., studies on root-knot in Argentina.................. 42, 61, 78

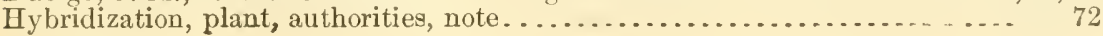


Iggulden, $W$., on control of root-knot....................... 56,78

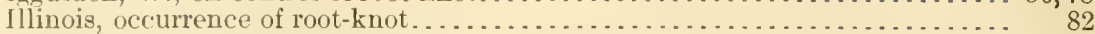

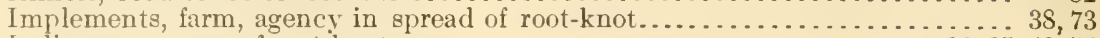

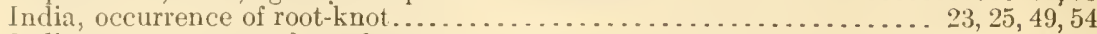

Indiana, occurrence of root-knot. . . . . . . . . . . . . . . . . . . 24,35

Inoculation, cross experiments with root-knot nematodes .............. 22-23

Introduction to bulletin. . . . . . . . . . . . . . . . . . . . . . . . . . . 7

Irish potato. See Potato, Irish.

Italy, occurrence of root-knot.

Jackson, A. D., experiments for control of root-knot. . . . . . . . . . . . 64, (68-69

Janse, J. M., on root-knot. ............................... 12, 17,78

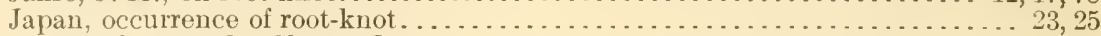
clover. See Clover, Japan.

Java, occurrence of root-knot. ............................. 8,23

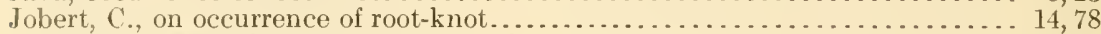

Johnson, J. . I., assistance in root-knot investigations. . . . . . . . . . . . . . 10 grass. See Andropogon.

Kafir, corn, resistance to root-knot. . . . . . . . . . . . . . . . . . . . . . . . 21

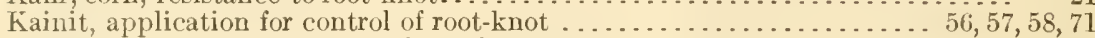

Kamerling, Z., on occurrence of root-knot............................. 13, 78

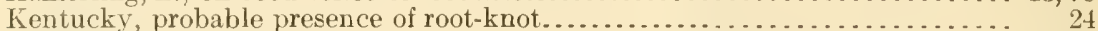

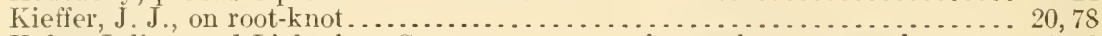

Kühn, Julius, and Liebscher, G., on occurrence of sugar-beet nematodes..... 61,78 on control of sugar-beet nematodes .............. . . . . 78,79

Laboratory, Subtropical. See Miami, Fla.

Lagerheim, N. G. von, on occurrence of root-knot............... 15, 16,79

Larva of root-knot nematode. See Heterodera radicicola, larva.

Lavergne, Gaston, on root-knot................... 9, 11, 18, 42, 61, 71, 79

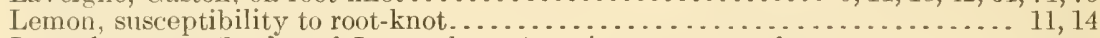

Lespedeza spp. (bush and Japan clovers), resistance to root-knot........... 16,69

Lettuce, susceptibility to root-knot......................... 16,22

Licopoli, G., on occurrence of root-knot........... 12, 13, 14, 15, 18, 19, 20, 21, 79

Liebscher, G., and Kïhn, Julius, on occurrence of sugar-beet nematodes...... 61,78

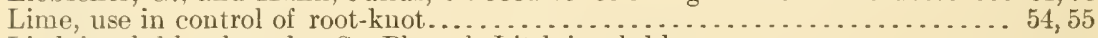

Little's soluble phenyl. See Phenyl, Little's soluble.

Lolium perenne, resistance to root-knot........................... . . . 21

Loosé, J. L., on treatment of roses for root-kiot....... . . . . . . . . . . . . . $47-48$

Lotsy, J. P., on occurrence of root-knot............................ 14, 79

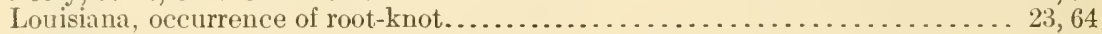

Lounsbury, C. P., on root-knot.........................

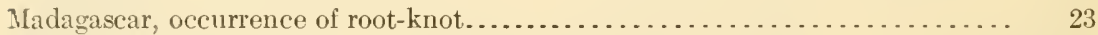

Magnus, P., on root-knot................................. 18,79

Manure, infested, relation to spread of root-knot.................. . $39,73-74$

Marcinowski, Kati, list of plants susceptible to root-knot............ 10, 11, 79

Maryland, occurrence of root-knot... . . . . . . . . . . . . . . . . . . . . . . . . 24

May, J. N., on control of root-knot on greenhouse plants. . . . . . . . . . . . 8,44, 79

Meloidogyne exigua, synonym of Heterodera radicicola . . . . . . . . . . . . . . . . 9

Mexico, occurrence of root-knot . . . . . . . . . . . . . . . . . . . . $23,40,49,61$

Miami, Fla., root-knot investigations................. .

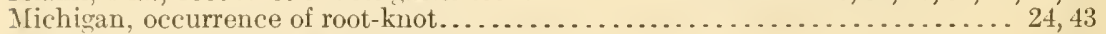

Millet, Japanese barnyard, resistance to root-knot............................. 21

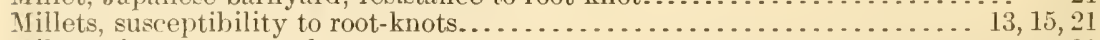

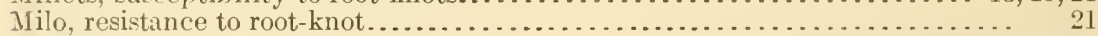

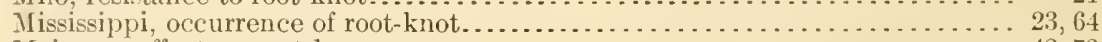

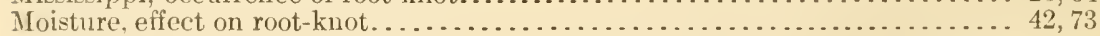
See also Drying and Flooding.

Molliard, Marin, on occurrence of root-knot... . . . . . . . . . . . . . . . . 12, 79

Molting. See Heterodera radicicola, molting.

Monetta, S. C., root-knot investigations........... . 9-10,43, 53, 54, 55, 56, 62, 65-68

Morning-glory, tree, susceptibility to root-knot.................. $16,22,82$

Mosseri, Victor, on occurrence of root-knot................... 13, 15, 19, 79

Mulberry, susceptibility to root-knot........................ $\ldots \ldots, 24,38,49,73$

Müller, C., on root-knot.............................. 8, 14, 17, 26, 79 
Münter, Julius, on occurrence of nematodes........................ 30,79

Muskmelon, susceptibility to root-knot........................... $14,22,59$

Neal, J. C., on occurrence of root-knot.................... . 9-21, 25, 69, 79

Nebraska, occurrence of root-knot........................... 24, 43

Needham, J. T., on occurrence of nematodes....................... . . 30,79

Nematode parasite. See Aphelenchus, Heterodera, Tylenchus, etc.

Neocosmospora vasiufecta, wilt fungus, analogy to root-knot............ 40, 71

New England, occurrence of root-knot............................ 24

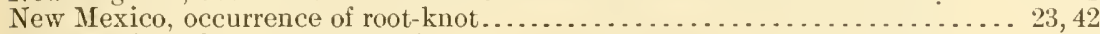

New South Wales, occurrence of root-knot........................ 9, 39

New York, occurrence of root-knot............................. 24, 43

New Zealand, occurrence of root-knot........................... 23

North Caroliua, occurrence of root-knot........................... 23, 64

Nursery, relation of stock to root-knot introduction . . . . . . . . . . . 24, 38, 73

Oats, resistance to root-knot....................... 12, 21, 65-67, 74

Ohio Agricultural Experiment Station, investigations of root-knot........ 46-47

Oklahoma, probable presence of root-knot. . . . . . . . . . . . . . . . . . . . 24

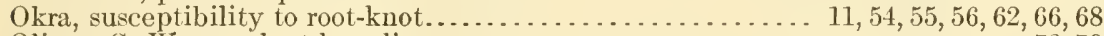

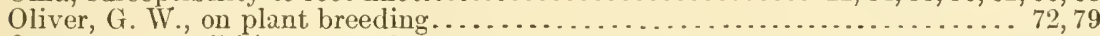

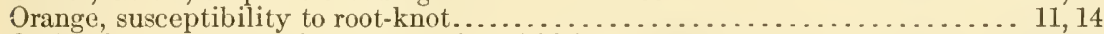

Orchards, treatment with carbon bisulphid for root-knot. . . . . . . . . . . 49-50,74

Orton, W. A., and Webber, H. J., on resistance of cowpeas to root-knot... . 65, 71,81 on studies relating to root-knot.............. 40, $72,79,82$

Osterwalder, Adolf, on occurrence of root-knot...................... 14,80

Panicum miliaceum. See Proso.

Papaya, susceptibility to root-knot. . . . . . . . . . . . . . . . 13, 22,49,50,51

Parasites, nematode. See Aphelenchus, Heterodera, and Tylenchus.

Pea, susceptibility to root-knot. . . . . . . . . . . . . . . . . . . . . 33

Peach, susceptibility to root-knot. . . . . . . . . . . . $12,23,24,38,49,59,73$

Peanut, susceptibility to root-knot....................... 12,65,74

Peglion, $V$. , on occurrence of root-knot. . . . . . . . . . . . . . . . . . . 14, 80

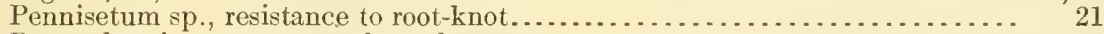

Pennsylvania, occurrence of root-knot............................ 24

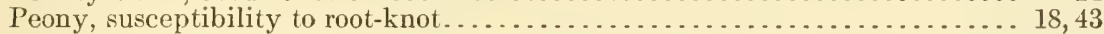

Phenyl, Little's soluble, use in experiments for coutrol of root-knot. . . . . . . . . 56

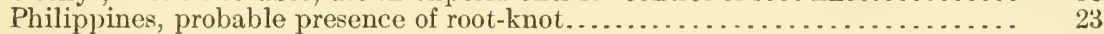

Phleum pratense. See Timothy.

Phosphate, acid, use for control of root-knot....................... 56

Phylloxera, measures for control as related to root-knot......... . 49, 50,51, 54, 71

Piper, C. V., on susceptibility of Stizolobium pruriens to root-knot......... 20,21

Plants, crop, resistant to root-knot....................... 21-22,65-69

greenhouse, treatment for root-knot....................... $47-48,74$

host, effects of attack of the root-knot parasite . . . . . . . . 7-8, 39-41,71

parts attacked by the root-knot parasite........... $7-8,39-40,75$ susceptibility to root-knot........................... $10-21,72$

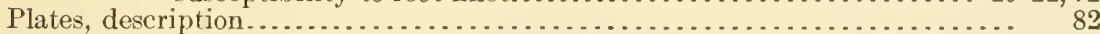

Potash in fertilizers, effect on root-knot in fields.......... $52,56-58,70-71,74-75$

Potassium magnesium carbonate, effect on root-knot.......... 56,57,58,71 sulphate, effect on root-knot........................ $56,57,58,71$ sulphocarbonate, experiments for control of root-knot......... 50,54

Potato, Irish, root-knot infestation and spread. . . . . . . . 19, 38-39, 40,69, 70,73

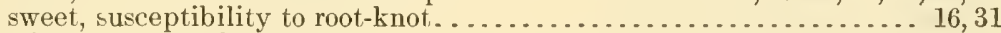

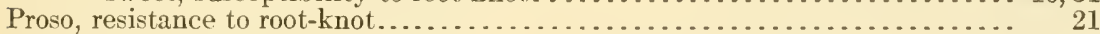

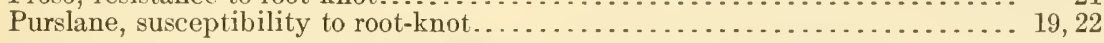

Queva, C., on occurrence of root-knot............................. 80

Quicklime. See Lime.

Radish, susceptibility to root-knot............................ 19,40

Rape, summer, use as trap crop for control of sugar-beet nematodes......... $61-62$

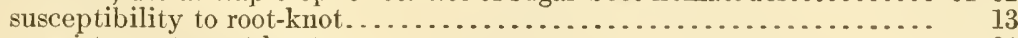

Redtop, resistance to root-knot. . . . . . . . . . . . . . . . . . . . . . . . . .

Reed, G. M., on plant breeding . . . . . . . . . . . . . . . . . . . . . . . . 72,80

Resistant strains. See Root-knot, breeding. 
Page.

Rhizoctonia, presence in plants treated for root-knot................ 54

Rhode Island, occurrence of root-knot. . . . . . . . . . . . . . . . . . . . . . 24

Ritzema Bos, J., on root-knot........................ 15, 20.22, 30,80

Rolfs, P. H., on root-knot............... 11, 17, 20, 21, 42, 60, 61, 65, 69, 80

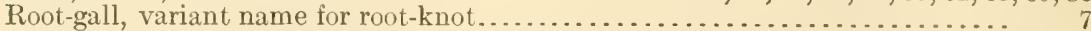

Root-knot, beaded, variant name for root-knot...................... 7

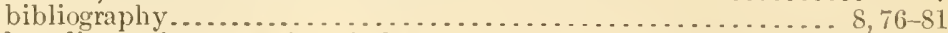

breeding resistant straius of plants................... $71-72,75$

causal parasite.................................. 25-41, 72,82 cross-inoculation experiments. . . . . . . . . . . . . . . . . 22-23,82 depth of galls below surface of soil. . . . . . . . . . . . . . . . . . 41,52 favoring conditions of soil, moisture, etc............... . . . . . 44,73 geographic distribution. . . . . . . . . . . . . . . . 8 8-9, 23-25, 72 historical notes.................................. 8-10,72 manner of introduction. . . . . . . . . . . . . . 23, 24-25, 37-39, 73-74

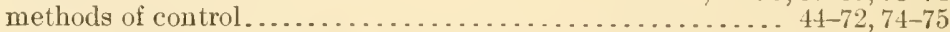

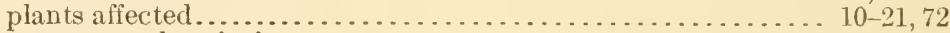
symptoms, description.............................. 7.8 variant names. . . . . . . . . . . . . . . . . . . . . . . . . $7,8-9$

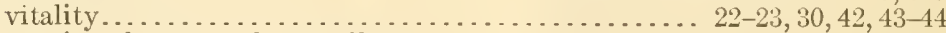

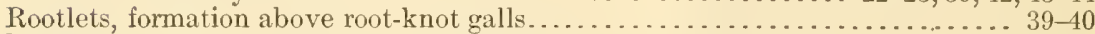

Root-rot, tobacco, control by steam sterilization.................. $63-64$ Roots, swellings. See Galls.

Rose, susceptibility to root-knot. .......................... 8,19

treatment for root-knot. . . . . . . . . . . . . . . . . . . . . . $47-48$

Ross, Hermann, on occurrence of root-knot. . . . . . . . . . . . . . . 12, 17, 20, 80

Rotations, crop, for root-knot control, experiments. . . . . . . . . . . . . 65-69, 74

Rübenmüdigkeit (beet tiredness), dne to a nematode. . . . . . . . . . . . . . . 61 .

Rudd, W. N., on occurrence of root-knot in greenhouses. . . . . . . . . . . . . . 44, 80

Russia, occurrence of root-knot............................... 23

Rye, relation to control of root-knot...................... 21, 65-69, 74

Sahara (oases), occurrence of root-knot. . . . . . . . . . . . . . . . . . 23

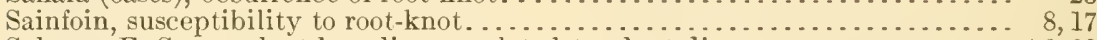

Salmon, E. S., on plant-breeding as related to plant disease.............. 72,80

Schlechtendal, D. H. R. von, on occurrence of root-knot............. 14, 80

Schroeder, C., on control of Tylenchus dipsaci ..................... 69,80

Secale cereale. See Rye.

Seed beds, methods for control of root-knot......... . . . . . . . . . . . . 44-48, 74 selection. See Selection.

Selby, A. D., on occurrence of root-knot.............. 12, 17, 19,44,46-47, 80

Selection, method for production of resistant plants.................... 72,75

Shamel, A. D., and Cobey, W. W., on strains of tobacco resistant to root-knot.. 71, 80

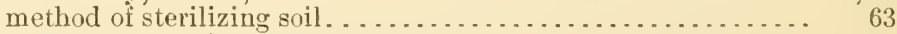

Sheldon, J. L., on occurrence of root-knot . . . . . . . . . . . . . . . . . . . . 20,80

Skeels, II. C., revision of names in list of plants susceptible to root-knot..... 10

Smith, R. E., and Stone, G. E., on root-knot. . . . 9, 15, 16, 22, 26, 27, 31, 36, 44. 45, 81

Soil, character, effect upon root-knot.................. $23,41,48,73$ fresh, use for control of root-knot nematodes. . . . . . . . . . . . . 45-46,74 infested, agency in spreading root-knot................... $37-39,73-74$ treatment for eradication of root-knot.................. $44-46,48,63-64,74$

Solidago spp., resistance to root-knot. . . . . . . . . . . . . . . . . . . . . . . 21

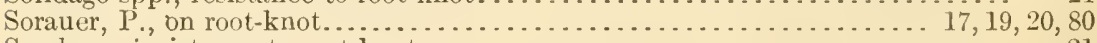

Sorghum, resistance to root-knot.................................. 21

South Africa. See Africa, South.

South America, occurrence of root-knot................. 9, 23,42,49,61

South Carolina, occurrence of root-knot. . 9-10, 23, 35, 43, 53-56, 57, 58, 62, 64, 65-68, 73 root-knot investigations. See Monetta, S. C.

Spillman, W. J., on plant breeding ........................... 72,80 Squash, susceptibility to root-knot............................ 14, $22,55,56-57,82$ Steam, live, use for control of root-knot. . . . . . . . . . . . . . . . 44-15, 46, 63-64, 74

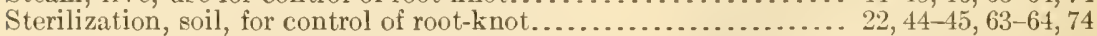
Stift, A., on control of sugar-beet nematode................... $57,59,80$ Stone, G. E., and Smith, R. E., on root-knot..... . 9, 15, 16, 22, 26, 27, $31,36,44,45,81$ on methods for control of root-knot................... 60,81

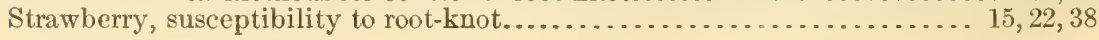


Strubell, Adolf, study of Heterodera schachtii.

Sturgis, W. C., on occurrence of root-knot........................... 12,81

Subtropical laboratory. See Miami, Fla.

Sugar cane. See Cane, sugar.

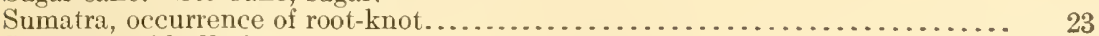

Summary of bulletin ... . . . . . . . . . . . . . . . . . . . . . . . . . . . $72-75$

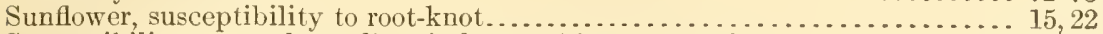

Susceptibility to root-knot, list of plants subject to attack............ 10-21, 72

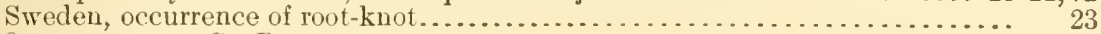

Sweet potato. See Potato, sweet.

Swellings, root-knot. See Galls.

Symptoms of root-knot. See Root-knot, synıtoms.

Syntherisma sanguinalis. See Crab-grass.

Tarnani, J., on occurrence of root-knot................... 15, 18, 20,81

Tea, susceptibility to root-knot................................. . 20,49

Temperature, conditions favorable to development of root-knot. . . . 24, 42-44, 73,74

Tennessee, probable presence of root-knot.......................... 24

Texas, occurrence of root-knot........................ . . $23,24,38,64,82$

Thielavia, root-rot of tobacco, control by sterilization................. $63-64$

Thornber, J. J., on occurrence of root-knot....................... 16

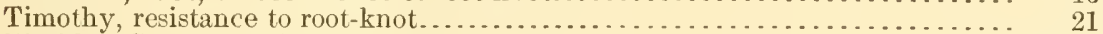

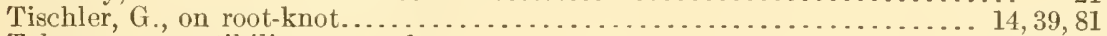

Tobacco, susceptibility to root-knot........................ 17, 22, 71

Tomato, susceptibility to root-knot........... 17, 22, 40, $44,55,56,62,66,68,69$

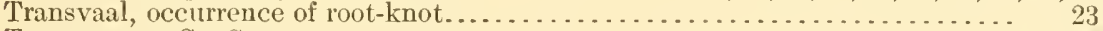

Trap crops. See Crops.

Trelease, William, on occurrence of root-knot.................... 14,81

Treub, M., on root-knot of sugar cane............................ 8,81

Trotter, Alessandro, on root-knot...................... $12,13,14,15,16,17,19,81$

Tylenchus hordei, cause of root-gall of Elymus arenarius................ 15

spp., comparison with Heterodera radiciola........... 22, 29, 30,69

synonyms for Heterodera radicicola ................... 9

Typha latifolia, stisceptibility to root-knot. . . . . . . . . . . . . . . . . 75

Utah, occurrence of root-knot . . . . . . . . . . . . . . . $36 \ldots \ldots \ldots$

Vehicles, wheels, agency in spread of root-knot . . . . . . . . . . . . . . . 38, 73

Velvet bean. See Bean, velvet.

Violet, susceptibility to root-knot........................ $8,21,30$

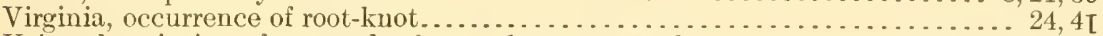

Voigt, description of egg sack of sugar-beet nematode......... $16,20,27,37,87$

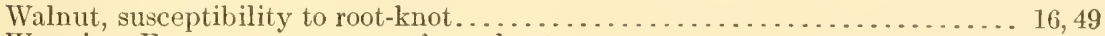

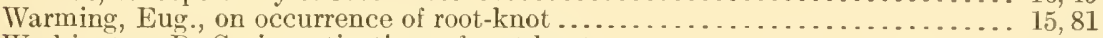

Washington, D. C., investigations of root-knot....................... . . $9,21,38$

Water, running, agency in spread of root-knot....................... 37

Watermelon, susceptibility to root-knot.................... 14, 40,59, 71

Webber, H. J., and Orton, W. A., on resistance of cowpeas to root-knot.... $65,71,81$ on occurrence of root-knot in Florida.................. 11

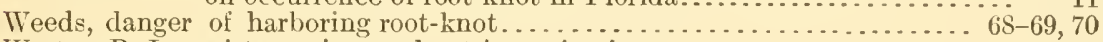

Wester, P. J., assistance in root-knot investigations. . . . . . . . . . . . . . . . 10

West Indies, occurrence of root-knot... . . . . . . . . . . . . . . . . . . . 25, 23

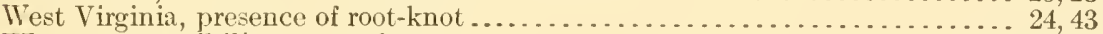

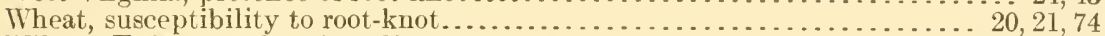

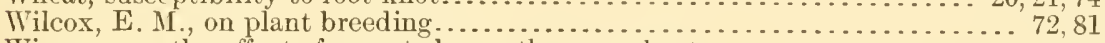

WVimmer, on the effect of nematodes on the sugar beet. . . . . . . . . . . . . 57-58

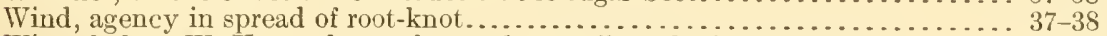

Winterhalter, W. K., analyses of sugar beets affected with root-knot........... . $40-41$

Wintering of root-knot. See Heterodera radicicola, overwintering.

Woods, A. F., investigations of root-knot......................... . 47

Yuma, Ariz., investigations of root-knot........................... 59

Zimmermann, A., on occurrence of root-knot.................. 11, 18, 81

Zinnia spp., resistance to root-knot.............................. 21 











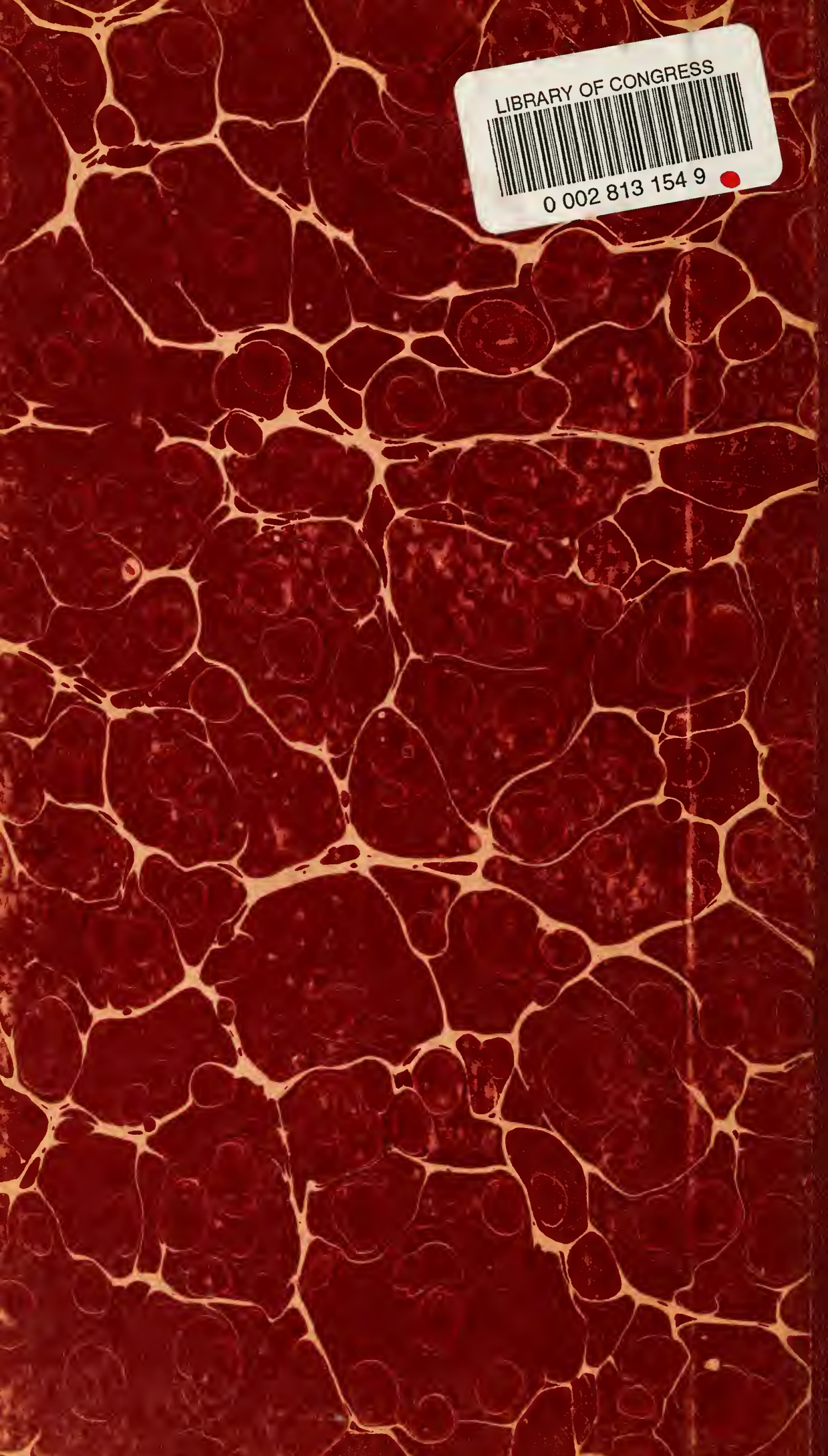

